\title{
BAGPIPE Containment Data and Phenomenology Report
}

\author{
N.R. Burkhard, R.A. Heinle, T.F. Stubbs
}

October 19, 2000

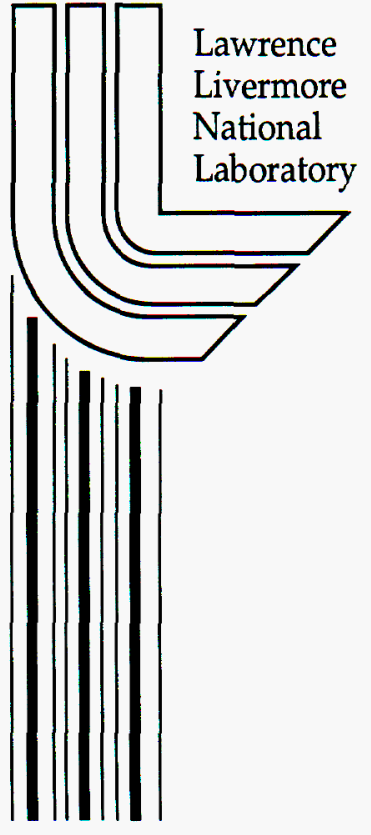




\section{DISCLAIMER}

This document was prepared as an account of work sponsored by an agency of the United States Government. Neither the United States Government nor the University of California nor any of their employees, makes any warranty, express or implied, or assumes any legal liability or responsibility for the accuracy, completeness, or usefulness of any information, apparatus, product, or process disclosed, or represents that its use would not infringe privately owned rights. Reference herein to any specific commercial product, process, or service by trade name, trademark, manufacturer, or otherwise, does not necessarily constitute or imply its endorsement, recommendation, or favoring by the United States Government or the University of California. The views and opinions of authors expressed herein do not necessarily state or reflect those of the United States Government or the University of California, and shall not be used for advertising or product endorsement purposes.

This work was performed under the auspices of the U.S. Department of Energy by the University of California, Lawrence Livermore National Laboratory under Contract No. W-7405-Eng-48.

This report has been reproduced directly from the best available copy.

Available electronically at http://www.doe.gov/bridge

Available for a processing fee to U.S. Department of Energy

and its contractors in paper from

U.S. Department of Energy

Office of Scientific and Technical Information

P.O. Box 62

Oak Ridge, TN 37831-0062

Telephone: (865) 576-8401

Facsimile: (865) 576-5728

E-mail: reports@adonis.osti.gov

Available for the sale to the public from

U.S. Department of Commerce

National Technical Information Service

5285 Port Royal Road

Springfield, VA 22161

Telephone: (800) 553-6847

Facsimile: (703) 605-6900

E-mail: orders@ntis.fedworld.gov

Online ordering: http://www.ntis.gov/ordering.htm

OR

Lawrence Livermore National Laboratory

Technical Information Department's Digital Library

http://www.llnl.gov/tid/Library.html 


\section{Contents}

Executive Summary ......................................................................................................

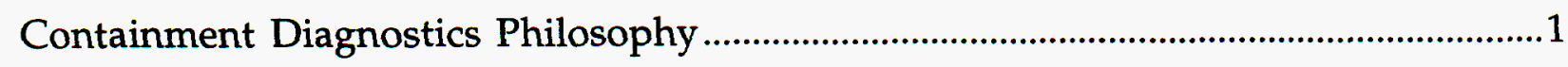

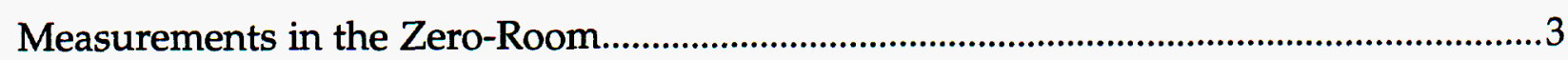

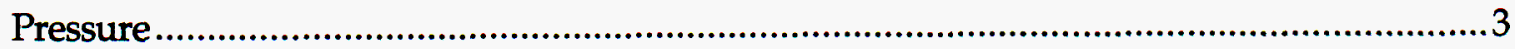

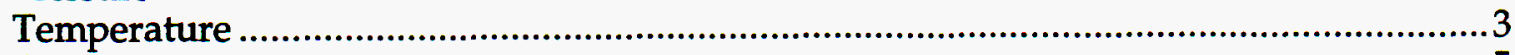

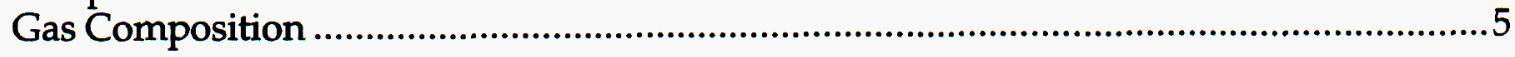

Measurements Outside the Zero-Room ...............................................................................

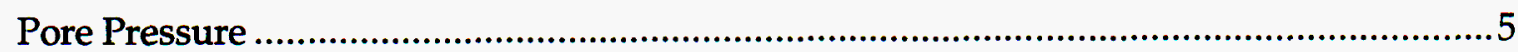

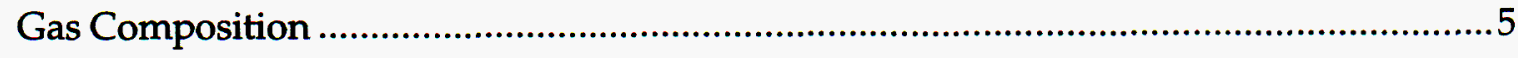

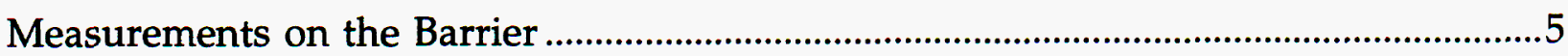

Motion of the Blast Barrier .........................................................................................

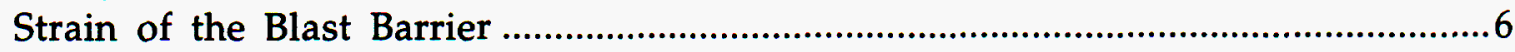

Porous Flow Calculations for the Zero-Room ....................................................................

Porous Flow Properties of the Geologic Media .................................................................

Pressure Decay in the Zero-Room Following Experiment Execution ............................... 8

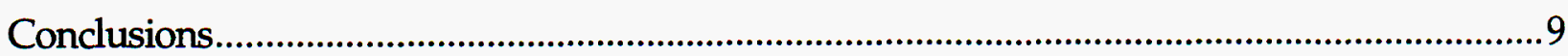

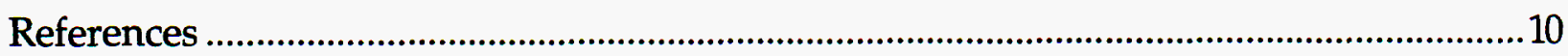

Appendix A: BAGPIPE Physics Instrumentation Plan ......................................................4

Appendix B: BAGPIPE Containment Diagnostics Requirements Memo .........................57 


\title{
BAGPIPE Containment Data and Phenomenology Report
}

\author{
Executive Summary
}

The BAGPIPE sub-critical experiment was executed on September 26, 1998, at about 13:07 hours. A steel and fibercrete containment barrier had been built at the entrance to the U1a.101b drift at the Nevada Test Site to form the BAGPIPE zeroroom. The invert of the zero-room was covered with concrete and the ribs and back were covered with about $15 \mathrm{~cm}$ of fibercrete. The face was left uncovered to facilitate gas bleed-off into the alluvial formation. The volume of the room was approximately $3894 \mathrm{ft}^{3}$. Four small experimental packages were detonated.

The LLNL containment goal for the BAGPIPE experiment was to confine all special nuclear material (SNM) to the zero-room and the alluvium surrounding the zero-room. The experiment and containment objectives are discussed more fully in the BAGPIPE Containment Prospectus ${ }^{1}$ and the associated addendum. ${ }^{2}$

Alpha-particle radiation detectors outside the BAGPIPE zero-room remained at pre-shot background levels after the experiment. A large number of swipes were taken around the BAGPIPE primary containment barrier and in the diagnostics room. No evidence that any SNM was released into the tunnel complex was found and the BAGPIPE containment was considered successful.

\section{Containment Diagnostics Philosophy}

BAGPIPE was the second LLNL sub-critical experiment. We are trying to understand the physics of the explosions as they affect the containment of SNM, the effects of the explosions on the containment barrier, and the flow of the zeroroom gas into the alluvium matrix. We calculated beforehand the pressure-time histories that might be observed and the resulting gas flow into the formation. Our diagnostics were defined both to monitor what happened, and to compare the results of the diagnostics with relevant calculations.

Two sets of calculations were performed. The BLASTX $\operatorname{code}^{3}$ Version 3.6 .3 was used to estimate the shock overpressures on the primary containment barrier and the zero-room quasi-static gas pressure for the initial configuration that was proposed for BAGPIPE. The BLASTX code allows the high explosive (HE) to be placed in the zero-room in positions approximating the actual locations of the HE during the experiment. Shock overpressures are calculated for specific locations. These estimates were used as input to the design calculations for the primary containment barrier. In addition, BLASTX calculates the quasi-static gas pressure produced by the detonation products of the explosive. The as-built configuration for BAGPIPE was different from the design that was calculated with BLASTX; the experiments were much further from the primary barrier than originally planned. There were four other differences: (1) as-built had a larger shrapnel barrier for the 
set of experiments in the alcove in the back of the zero-room than originally planned, (2) as-built had shrapnel shields for the experiments close to the barrier, (3) as-built had the HE in target cubes instead of "bare" HE at the target locations, and (4) the effects of the metal tables and other equipment in the zero-room were not included in the design calculations. The combined effect of these differences is to reduce the shock overpressures on the primary barrier.

To evaluate gas transport, porous flow calculations were done using the NUFT code. ${ }^{4}$ The zero-room and surrounding tunnel environment was mocked up in three dimensions. The geologic medium (alluvium), containment barrier, concrete invert, and fibercrete ribs and back were mocked up in the calculation. The zeroroom was initialized with the estimated temperature, pressure, and explosive gas concentrations and the resulting pressure and gas concentrations were calculated. With these calculations in mind, the zero-room was instrumented for temperature, shock (blast) overpressures, and quasi-static gas pressure.

Extensive DYNA ${ }^{5}$ calculations were conducted for the primary containment barrier during its design. We wanted to evaluate the DYNA modeling to determine how conservative our barrier design might be. We therefore measured strain at many places on the containment barrier so that we could compare calculated and measured strain data on the experiment. Another design issue was whether the fibercrete and steel of the containment barrier would act as one element or delaminate during the experiment. A large number of Nelson studs were used to help "fix" the fibercrete to the steel. Accelerometers were placed on the steel and on the fibercrete to determine whether there was relative displacement between these two during the experiment.

The diagnostics and the physics instrumentation plans (reproduced from Bechtel Nevada documents) are in the Appendix. The BAGPIPE Containment Diagnostics Requirements memo is included for completeness. 


\section{Measurements in the Zero-Room}

\section{Pressure}

Quasi-static gas and shock overpressures were measured in the zero-room during the BAGPIPE experiment. The quasi-static gas pressure gauges were also able to respond quickly enough to measure some of the shock overpressures. These gauges, 10_PX and 11_PX (Figures 1 and 2), show the pressure history in the zero-room. Both gauges indicate an initial quasi-static gas pressure of about 24 psia which is consistent with the pre-shot BLASTX calculation of 11 psig. This pressure depends upon zero-room volume and the amount and type of $\mathrm{HE}$ used in the experiment. The quasi-static pressure decays both because of cooling of the gas in the zero-room and because of pressure-driven porous flow of the gas into the formation. By 300 seconds

(5 minutes), the pressure in the zero-room has returned to approximately the ambient pre-shot pressure level.

Shock overpressures were monitored at seven locations on the barrier (stations 2_OP to 8_OP) and one on the right rib directly opposite the alcove (station 1_OP) containing experiments 1 and 2. These gauges do not respond to the low-frequency variations in gas pressure; hence these gauges only record the rapidly decaying shock overpressures and do not "see" the quasi-static gas pressure. Six of the seven locations on the barrier yielded believable pressure waveforms; the first $300 \mathrm{~ms}$ of these are shown in overlay form in Figure 3. The shock overpressure time histories are somewhat different from those that would be calculated with BLASTX. However, this was not unexpected, for the reasons cited above. These pressure-time histories show that the shock overpressures rapidly decay and are essentially gone by $100 \mathrm{msec}$. Station 1_OP (not shown) was consistent with the blast door pressures, but with a peak of close to 30 psig, occurring near zero time.

\section{Temperature}

Six transducers monitored the temperature in the zero-room. Within the complement were four infrared (IR) thermometers (stations 60_IRa and b and 61_IRa and $b$ ), one high-speed thermocouple (station 30_TC), and one YSI resistance thermometer (station 31_TH).

The sensitive elements of the IRs were directional and mounted to observe different portions of the room; the " $b$ " components monitored the left rib while the "a" components were aimed toward the center of the room. Station 60 was mounted about $8 \mathrm{~cm}$ above the invert and station 61 was about 2.4 above the invert.

Unfortunately, during construction, after the gauges were mounted, other equipment was installed that placed station 60 in a "shadow" relative to experiments 3 and 4 . Figures 4, 5, and 6 show the outputs of the four IR transducers. Note that stations 61_IRb and 60_IRa show roughly the same waveform at early time (the temperature profile of reflected and re-radiated energy). 61_IRa, the only transducer with a free-and-clear view of the center of the room, shows the highest 
early temperature. The early time of the transducer 60_IRb (sensing the rib from about $8 \mathrm{~cm}$ above the invert and in the shadow) indicates a much lower early time temperature with no initial spike. The late-time waveforms of both channels of 60_IR are identical, as are both channels of 61_IR. The late-time (greater than 240 s) waveforms reported by all the IR transducers tend to approximate that of the gas pressure reported by stations 10 and 11 (Figures 1 and 2).

Figures 7 and 8 show the outputs of the thermistor and thermocouple (stations 30 and 31) which were mounted $2.3 \mathrm{~m}$ above the invert on the left rib of the room. The thermocouple was exposed directly to the blast while the thermistor was blast-shielded. Comparison of the first 5 seconds of these two suggests that thermal radiation from the detonation caused an early-time jump in the thermocouple, which was then followed by a gradual increase to a maximum of around $56^{\circ} \mathrm{C}$ at about 1 minute after detonation. The waveforms between 1.5 and $5 \mathrm{~s}$ of both stations 30 and 31 are consistent except for a $6^{\circ} \mathrm{C}$ offset. The peak registered temperatures are separated by about $10 \mathrm{~s}$ and $2^{\circ} \mathrm{C}$, with the thermistor being the later and higher. At late times (after $800 \mathrm{~s}$ ) both stations registered $32^{\circ} \mathrm{C}$.

A simple "perfect gas law" calculation applied to the pressure of station 10 yields a temperature waveform that is close to the early time data (before $15 \mathrm{~s}$ ) of station 61_Ira (Figure 21). At later times the derived waveform falls below that of the direct temperature measurements and is at ambient pre-shot level at $1000 \mathrm{~s}$. This may be attributed to loss of gas to the formation, reducing the pressure while the room remained at an elevated temperature. The late time $(\sim 1000 \mathrm{~s})$ temperature near the invert (stations 60_IR) is about $4^{\circ} \mathrm{C}$ less than at the center elevation of the room (stations 61_IR) and about $5^{\circ} \mathrm{C}$ less than that measured at stations 30 and 31 . This suggests that the gas in the room became stratified within 15 minutes after detonation.

We conclude from examining the pressure and temperature data the following regarding the pressure and temperature in the zero-room:

1. The pressure transducer, 10_PX, is actually measuring the average gas pressure in the zero-room.

2. The IR thermometers pointed at the left rib are picking up the temperature of that rib. At late times, the temperature of the rib equilibrates with the temperature of the gas. The $a$ and $b$ channels converge to the same temperature.

3. There is some stratification of the gas in the zero-room at late times. At about 15 minutes, the lower IR gauge reads about $30^{\circ} \mathrm{C}$ and the upper gauge reads about $35^{\circ} \mathrm{C}$.

4. The thermocouple and the thermister near the rib do not follow the zero-room temperature very well at all. They are unable to respond to the fast peak of the temperature, probably because of their thermal mass. 


\section{Gas Composition}

The first 3 minutes of the history of oxygen, carbon dioxide, and carbon monoxide in the zero-room (station 70) are shown in Figure 9. The carbon monoxide (CO) transducer gave an erratic output and the early-time portion of the oxygen waveform (the first $40 \mathrm{~s}$ ) was compromised, as shown. However, the oxygen and carbon dioxide were generally as expected from our calculations.

\section{Measurements Outside the Zero-Room}

\section{Pore Pressure}

Pore pressure was monitored at six locations. Each station was placed in a borehole, packed with organic fiber, sealed in with sulfaset, and the hole grouted. There were four stations (stations $41,42,43$, and 44) in the formation that were accessed from the zero-room; 42 and 43 were in bore holes in the face that was left bare while the other two were behind the fibercrete on the left and right ribs. The remaining two (stations 40 and 45) were accessed from the drift U1a.101. The upper plot of Figure 10 shows an overlay of all the pore pressure histories of those stations that were accessed from the zero-room while the lower plot gives the pore pressure histories of stations 40 and 45.

\section{Gas Composition}

In addition to pore pressure sensors, stations 42 and 45 included $\mathrm{CO}$ detectors. Measurements of $\mathrm{CO}$ at station 42 , in the formation, and station 71, in drift U1a.101, are shown in Figure 11 covering a period of 50 hours after the event. The gas was detectable at station 42 about 2 hours after the event while levels in the drift (station 71) were slight and increasing until about 22 hours when the exhaust activity was begun. No $\mathrm{CO}$ was seen at station 45 until workers entered the drift about 10 days after the event and activated a test source to exercise the sensor. The entire measured history of stations 42, 45, and 71 is shown in Figure 12.

\section{Measurements on the Barrier}

\section{Motion of the Blast Barrier}

Both the inside and outside of the blast door were instrumented for acceleration at a position near its center. A single, radially oriented transducer was fastened to the metal skin on the outside (station 82) and another was placed on the surface of the fibercrete layer on the inside of the door (station 80). A third station (triaxial) was fielded on the outside of the door and affixed to a block of redwood which was expected to act as a shock absorber (station 81). The first $200 \mathrm{~ms}$ of the motion of station 80 is shown in Figure 13. 
Frequency content of the three radial signals is shown in Figure 14 by the pseudo-relative velocity representation of the response spectrum. Under certain conditons this is the Fourier spectrum but with equal spacing in the logarithm of the frequency. Two differences are seen in the plots: station 80 is higher than the other two at frequencies less than $15 \mathrm{~Hz}$ and station 81 indicates two regions of high amplitude at frequencies above $1500 \mathrm{~Hz}$ that are not seen in the other two. Although not shown here, the derived radial displacements of stations 81 and 82 are identical to within the limits of the accuracy of the transducers. The redwood block seems to have introduced high frequencies without introducing significant differences in the second integration (displacement) of the signal. The peak vertical and horizontal transverse displacements of station 81 are about $20 \mu \mathrm{m}$.

The integrity of the fibercrete liner on the barrier door has been questioned, in particular as to whether it delaminates from the steel of the door. Figure 15 shows an overlay of the first $200 \mathrm{~ms}$ of the derived dynamic displacements of the inside and outside of the blast door along with the numerical difference of the two histories. A peak change (decrease) in the separation between the two stations of about $0.6 \mathrm{~mm}$ is seen at about $80 \mathrm{~ms}$ with the residual separation being a decrease of about $0.5 \mathrm{~mm}$. The waveform of the separation does not indicate spall delamination. The resulting mechanical integrity of the material of the fibercrete cannot be determined from these data.

\section{Strain of the Blast Barrier}

The steel of the portal side of the barrier was instrumented for strain at 13 locations, including three strain rosettes. An additional four locations embedded in the grouting near the perimeter of the barrier were monitored, including a triaxial station in the keyway. On the working-point side of the barrier, strain was monitored in the fibercrete at five locations. The first $500 \mathrm{~ms}$ of one characteristic strain history (station 113, near the center of the portal side of the barrier) is shown in Figure 16. The pressure history of station 11 is overlaid with the ambient level removed and the amplitude (in psi) amplified by a factor of 2.4. There is a close correlation of the gas pressure within the zero-room and the strain on the barrier.

The fibercrete near the perimeter of the barrier was instrumented for strain at five locations. The first $300 \mathrm{~ms}$ of data from these transducers is shown in Figure 17. All stations registered a peak of around $20 \mu$ strains. Noise in the form of many brief "fliers" may be due to crushing and relaxation of the fibercrete.

Portal side stations 104-107 and 112 on the steel of the barrier show much the same behavior except for a reversal of polarity (Figure 18) and an absence of the noise spikes seen in the embedment gauges. Stations 108-111 (Figure 19) show the same waveform as stations 104-107 except reversed to the same polarity as the working-point embedment stations. Stations 108 and 109, however had a much 
reduced amplitude. Characteristic of the embedment gauges on the portal side is 97 , also shown in Figure 19.

Figure 20 is a display of the principal axis strain measurement of the rosette of station 101, at the central column next to the access port in the barrier. The angle is that through which the principal axes were rotated from the original mounting position. One of the components of station 100 did not fully respond and station 102 was much like station 101 .

DYNA was used to determine the strain that the barrier would "see" during the experiment. A comparison of the original peak predicted strain for each gauge, the peak measured strain, and the revised peak predicted strain are shown in Figure 22. The original peak predicted strain was calculated using pressure loading from BLASTX. The original explosive loading for the calculation was much larger than was actually used during the experiment. Figure 22 shows a comparison between the measured strains and the revised calculated strains using the HE load that was actually used during the BAGPIPE experiment. Figure 20 shows that the barrier was greatly over-designed (in terms of strain) for the HE load actually used. Figure 21 shows that the calculated and measured strains compare quite favorably. In general, the calculated strains are still larger than the measured strains. This is to be expected since the calculated pressures from BLASTX assume "bare" HE (i.e., the HE is not in a container). The actual BAGPIPE HE was inside a container and this would reduce the pressure loading that the barrier would see. Figure 23 shows that the combination of BLASTX pressure loading and DYNA simulation in general lead to conservative estimates of the barrier strain. The estimates generally agree within a factor of two or less.

\section{Porous Flow Calculations for the Zero-Room}

\section{Porous Flow Properties of the Geologic Media}

The final pressure test of the Bagpipe primary containment barrier was used to determine the geologic properties surrounding the BAGPIPE zero-room that would impact porous flow from the zero-room. The pressure test data were successfully modeled using a simple model that had three materials: alluvium, a thin layer of "broken" alluvium surrounding the zero-room (about 12 inches thick), and fibercrete (6 inches thick). The porous flow parameters for these materials were determined by determining a "best" fit to the pressure test data when a simple model was calculated with NUFT using a simple iterative process (Table 1). 
Table 1. Porous flow properties of geologic media surrounding the BAGPIPE zero-room.

\begin{tabular}{l|c|c}
\hline Medium & $\begin{array}{c}\text { Gas-filled porosity } \\
\text { (vol\%) }\end{array}$ & $\begin{array}{c}\text { Permeability } \\
\text { (Darcies) }\end{array}$ \\
\hline Alluvium & $9 \%$ & 0.8 \\
"Broken" alluvium & $15 \%$ & 8.0 \\
Fibercrete & $2 \%$ & 0.02 \\
Emissivity of gas" & 0.1 & \\
\hline
\end{tabular}

a Roughly estimated from the literature.

The pressure test data were matched quite well. The decay of the pressure in the zero-room was matched very well (Figure 24). The pore pressure gauges in the formation were matched using the parameters from Table 1 (Figures 25 and 26).

\section{Pressure Decay in the Zero-Room Following Experiment Execution}

After the HOLOG experiment, it was found that the zero-room pressure decayed about five times faster than the pressure decay rate that was measured during the pressure tests of the room. By allowing the HE gases in the NUFT calculation to radiate energy to the walls of the zero-room, the pressure decay rate and the shape of the decay curve were matched. This was illustrated in Figure 4 of the HOLOG Containment Phenomenology Report. ${ }^{6}$

After the BAGPIPE experiment, we tried to determine whether radiation was actually necessary in order to get reasonable agreement between the measured and calculated pressure curves. To do this, we modeled the gas in the zero-room with a range of thermal conductivities. The gas in the zero-room is actually a combination of HE detonation gases, SNM particulates, experiment zero-room air, and other particulates including dust particles. Determining the actual thermal conductivity of the mixture of gas and aerosol in the zero-room without knowing its composition is almost impossible. Therefore, we calculated the pressure decay with several different values of thermal conductivity for a gas. Figure 27 illustrates these results. What is not accounted for in these calculations is the turbulence that the explosion itself produces in the room. The turbulence would move the hot gas into contact with the cooler gas and the cool zero walls faster than would occur naturally. This would produce more rapid cooling (and hence pressure decay) since the hot gas would itself be physically transported to the cooler material where the heat could be then conducted "out" of the gas.

Note that a thermal conductivity significantly greater than that of air, $\mathrm{CO}$, or $\mathrm{CO}_{2}$ is needed to match the measured pressure decay. A thermal conductivity in the range of $10-100 \mathrm{~W} / \mathrm{m}{ }^{\circ} \mathrm{C}$ is needed to approximately match the measured pressure decay. Air and other gases like $\mathrm{CO}$ have thermal conductivities of about $0.02-0.05 \mathrm{~W} / \mathrm{m}{ }^{\circ} \mathrm{C}$. Metals like iron and aluminum have a thermal conductivity in the range of $80-200 \mathrm{~W} / \mathrm{m}{ }^{\circ} \mathrm{C}$. An aerosol composed of $\mathrm{HE}$ gas products, air, and 
metal particulates that undergoes turbulent mixing in the zero-room could effectively have a thermal conductivity in this range. The turbulent mixing puts the hot aerosol in close proximity to cool surfaces so that heat can be more rapidly conducted to the cool materials. The more rapid the cooling of the hot aerosol, the faster the pressure drops in the zero-room.

The resulting pressure drop in the zero-room is also a function of the type of material that the hot aersol contacts. Iron has a thermal conductivity which is about 50 times larger than concrete. The HOLOG calculation assumed that the hot aerosol conducted and radiated only to the fibercrete walls. In the BAGPIPE experiment, iron and aluminum plates present in the experiment stands, shrapnel shields, and other locations present a reasonably large surface to which the hot aerosol could conduct heat. We estimated the total surface area of the plates and performed new NUFT simulations to determine the effect that these metal plates would have upon the pressure decay. As expected and seen in Figure 28, the surface area of the metal does reduce the pressure faster; however, the effect for BAGPIPE is not dramatic.

Without total proof, we conclude that the pressure decay does not require that significant quantities of heat be transported by radiative heat transfer mechanisms. It appears that a combination of thermal conduction, thermal convection, turbulent mixing, and an increased thermal conductivity for the gas (the gas is actually an aerosol with a higher thermal conductivity than gas by itself) can probably account for the pressure decay in the zero-room. While some of the pressure decay is due to porous flow into the formation, most of the pressure drop is due to the decrease in temperature as illustrated in Figure 21. A comparison of Figures 1 and 28 also confirm that the rapid pressure decay is not solely due to porous flow.

In summary, we can approximate the pressure decay in the zero-room without having to utilize radiative heat transfer mechanisms. While radiative heat transfer does contribute to the pressure decay in the zero-room, it is probably not a significant factor in rapidly reducing the temperature of the aerosol in the room. The pressure decay in the zero-room is primarily the result of the reduction in the temperature of the aerosol; heat is conducted to concrete and steel surfaces in the zero-room aided by convection and turbulent mixing.

\section{Conclusions}

BAGPIPE was successfully contained. In general, the predicted pre-shot phenomenology was confirmed by measured data from the experiment. The pressures and gas composition in the zero-room were generally as expected. The measured strains agree with the strains that were calculated from the measured pressures. This helps confirm that the DYNA model for the barrier is reasonable. Porous flow modeling for the pressure decay in the zero-room suggests that the pressure decay in 
the zero-room is primarily the result of the reduction in temperature of the aerosol. The temperature decay in the aerosol is the result of heat being conducted to the concrete and steel surfaces in the zero-room aided by convection and turbulent mixing.

Overall, BAGPIPE was a very successful experiment. Full containment was achieved without compromise to the physics diagnostics data. In addition, the data reported in this document form the basis for future SCE designs that utilize the barrier and alcove concept.

\section{References}

1. Burkhard, N. R., "Containment Prospectus for the BAGPIPE Experiment," Lawrence Livermore National Laboratory, Livermore, CA, CP98-01, March 18, 1998.

2. Burkhard, N. R., “Containment Update for the BAGPIPE Experiment," Lawrence Livermore National Laboratory, Livermore, CA, August 27, 1998.

3. Britt, J. R., and M. G. Lumsden, Internal Blast and Thermal Environment from Internal and External Explosions: A User's Guide for the BLASTX Code, Version 3.6.3, SAIC 405-94-2, May 16, 1994.

4. Nitao, J. J., User's Manual for the USNT Module of the NUFT Code, Version 1.0, Lawrence Livermore National Laboratory, Livermore, CA, March 20, 1996.

5. Whirley, R. G., DYNA3D: A Nonlinear, Explicit, Three-Dimensional Finite Element Code for Structural Mechanics, Lawrence Livermore National Laboratory, Livermore, CA, UCRL-MA-107254-Rev-1.

6. Heinle, R., T. Stubbs, and N. Burkhard, HOLOG Containment Phenomenology Report, Lawrence Livermore National Laboratory, Livermore, CA, UCRL-ID128832, 1997. 
Figures 


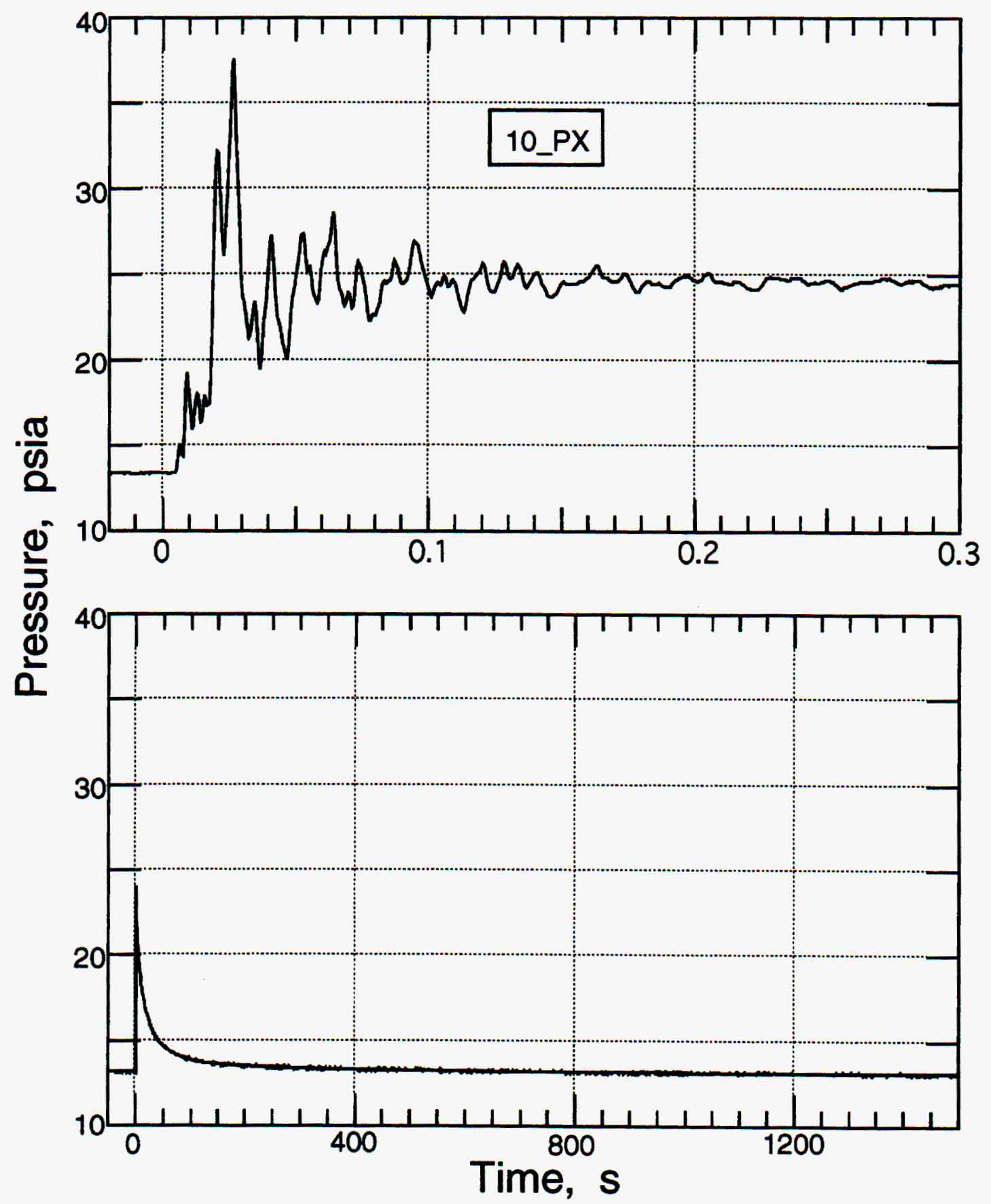

Figure 1 Quasi-static pressure measured in the zero-room on the left rib at about $1.7 \mathrm{~m}$ above the invert (station 10). 


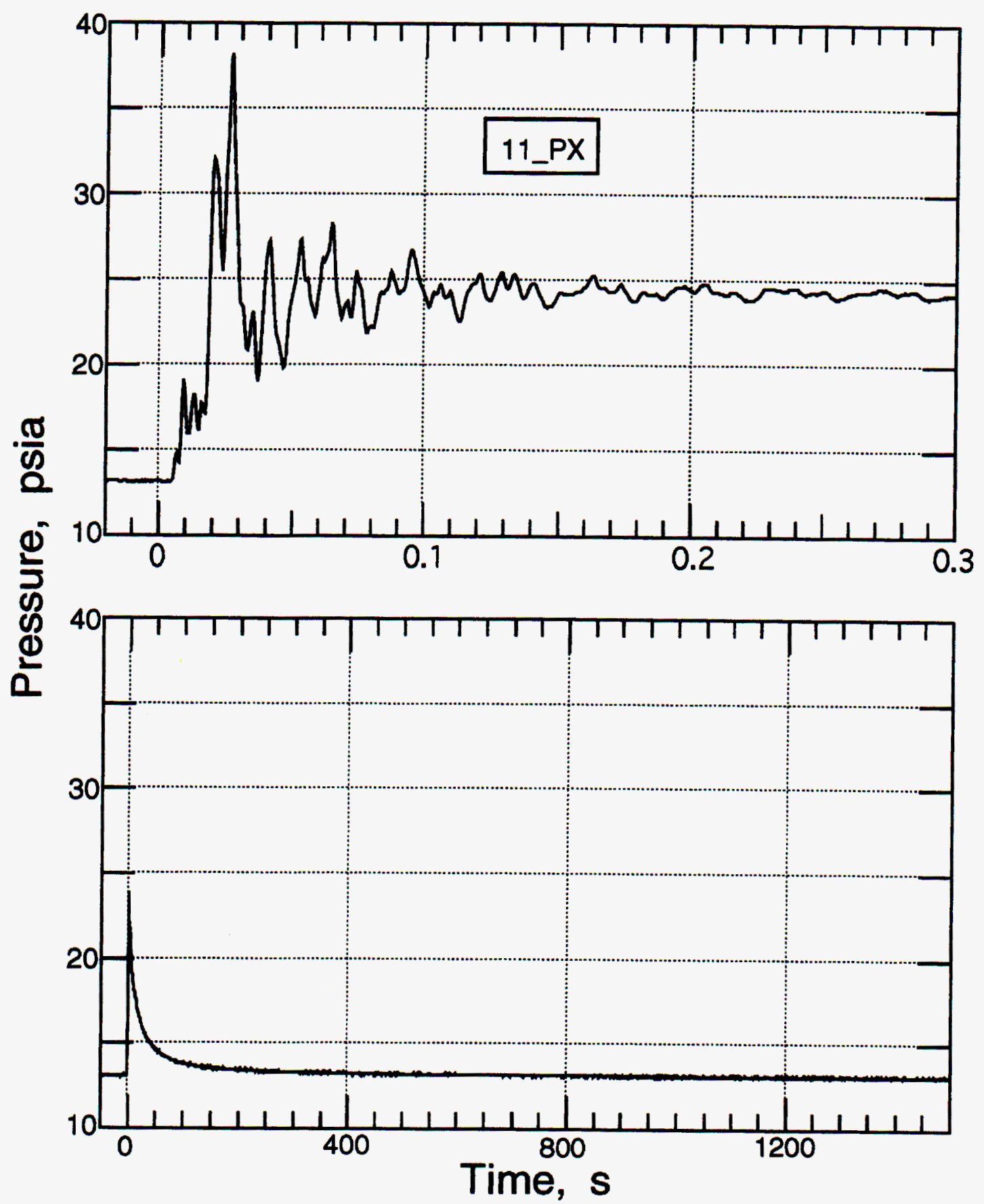

Figure 2 Quasi-static pressure measured in the zero-room on the left rib at about $1.7 \mathrm{~m}$ above the invert (station 11). 

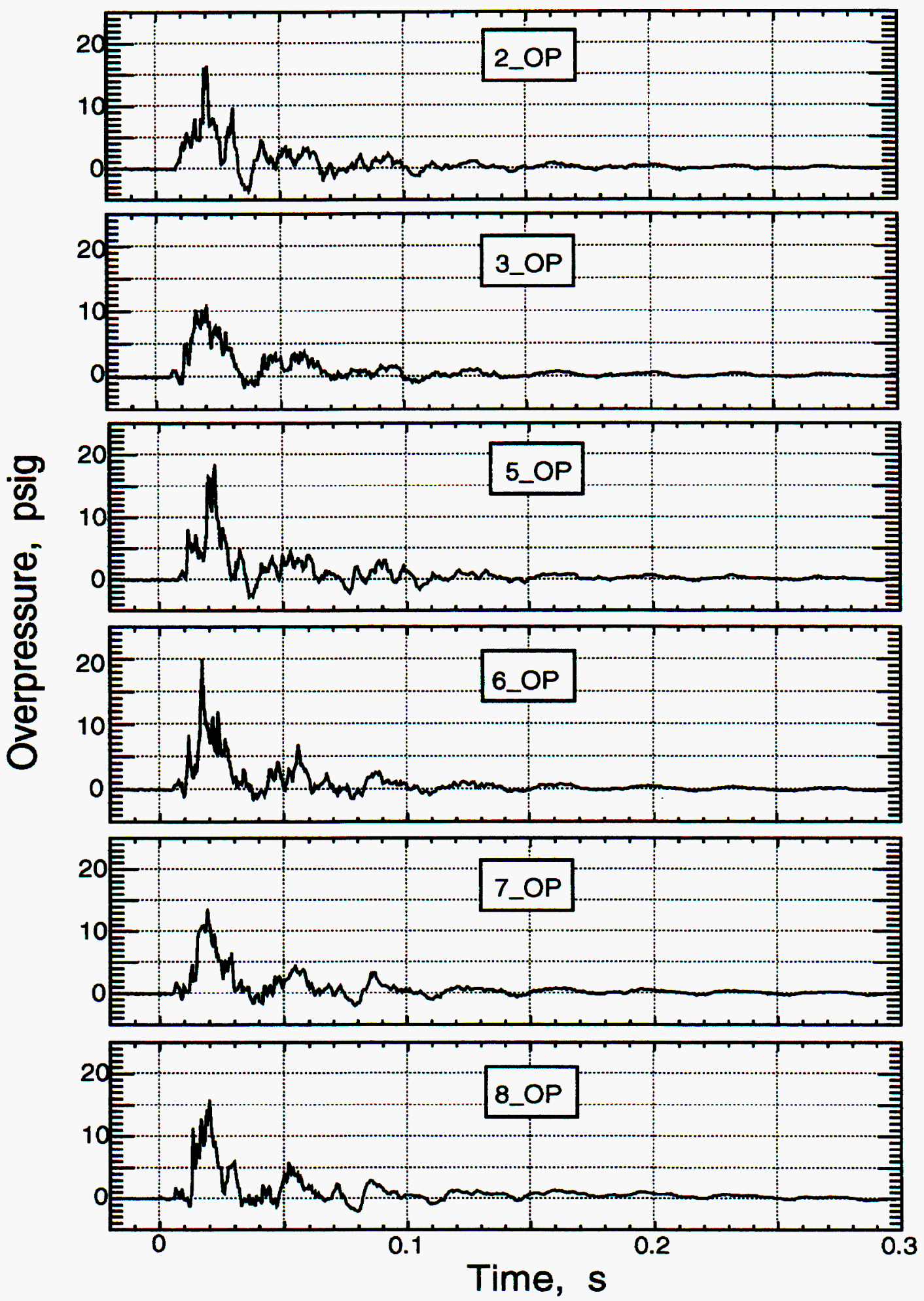

Figure 3 Shock over-pressure measured on the blast barrier in the zero-room. Differences in the waveforms may be attributable to reflections from the contents of the room. 


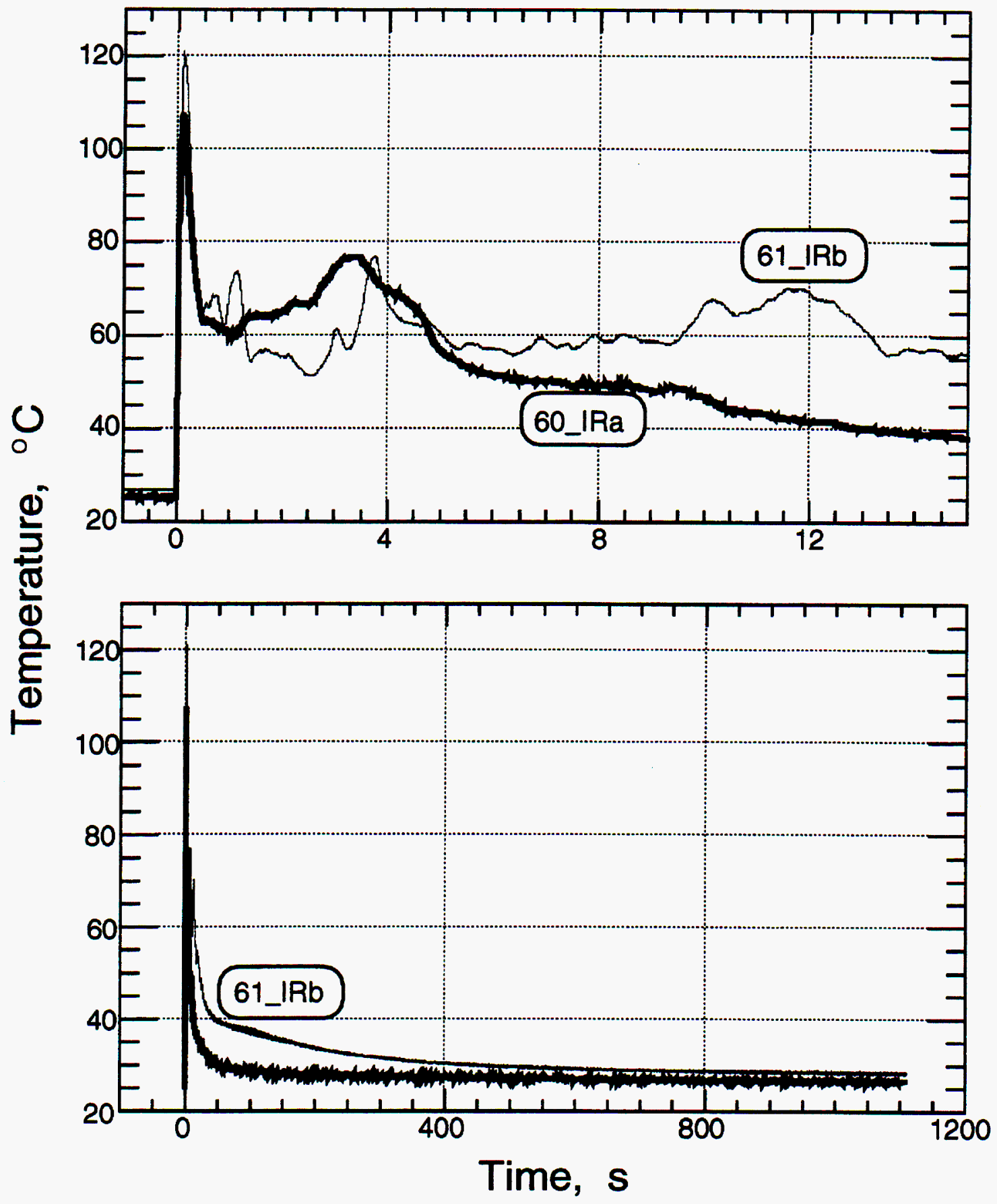

Figure 4 Temperature in the zero-room measured by infrared thermometers. 60a was aimed into the room from an elevation of $8 \mathrm{~cm}$ above the invert, but was occluded by material placed between it and the experiment. $61 \mathrm{~b}$ was aimed at the left rib from an elevation of 2.4 above the invert. The heavier trace displays the data from station 60 , near the invert. 


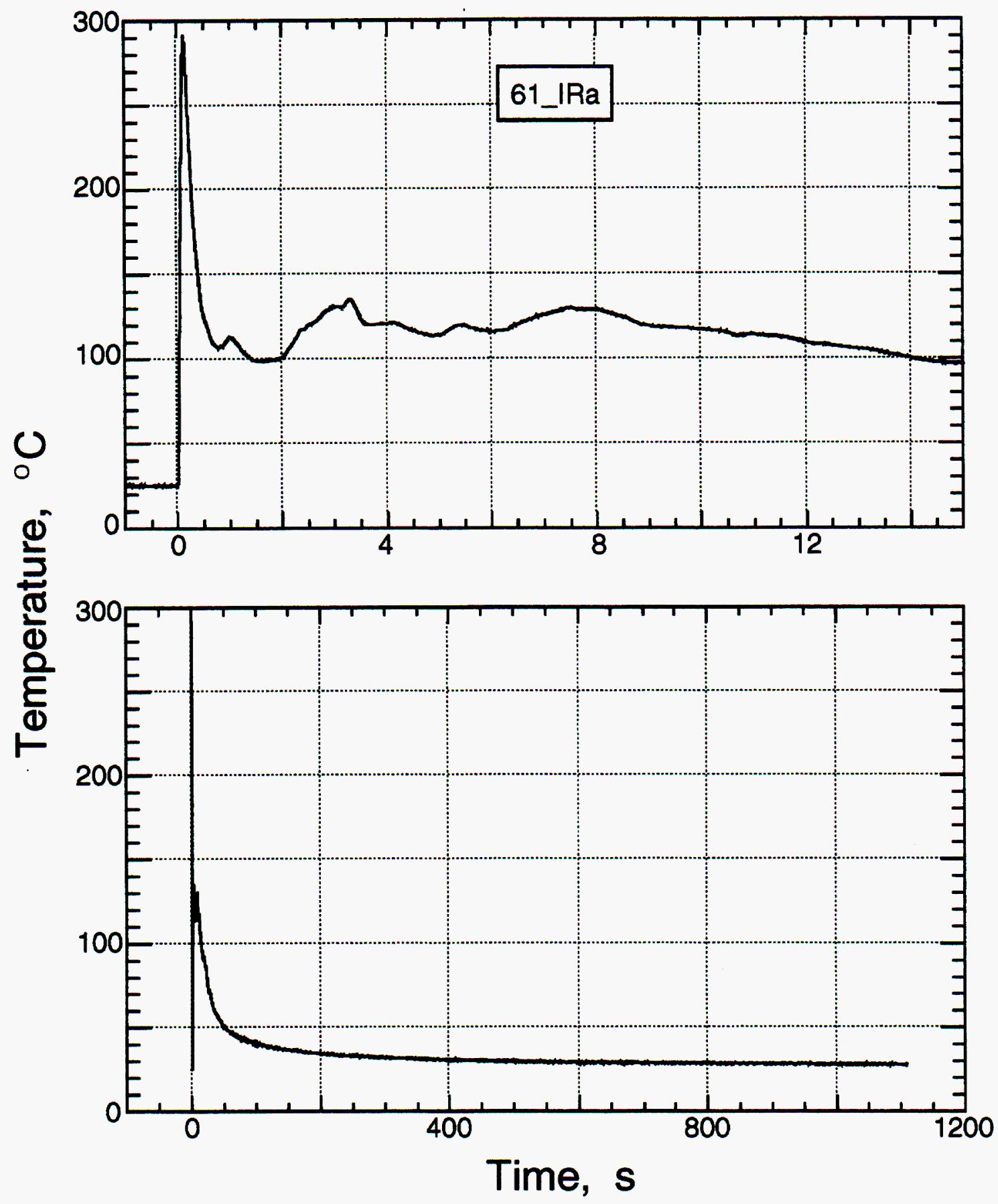

Figure 5 Temperature in the zero-room measured by infrared thermometer at station 61, aimed into the central portion of the room from an elevation of about $2.4 \mathrm{~m}$ above the invert. 


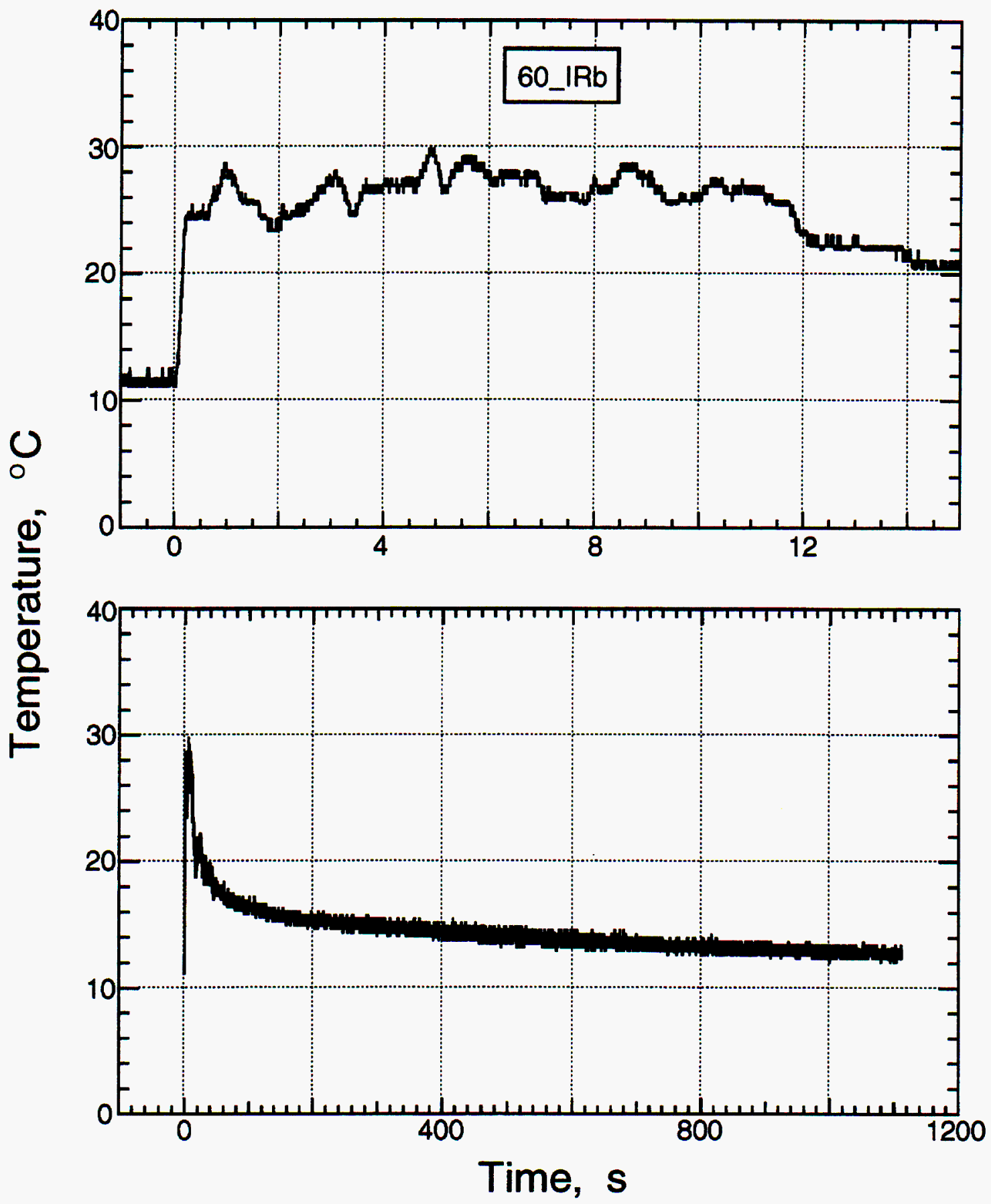

Figure 6 Temperature in the zero-room measured by infrared thermometer at station 60 aimed at the left rib about $8 \mathrm{~cm}$ above the invert. This transducer was in the shadow of the material occluding the experiment and the rib was in the secondary shadow of the transducer mounting. 

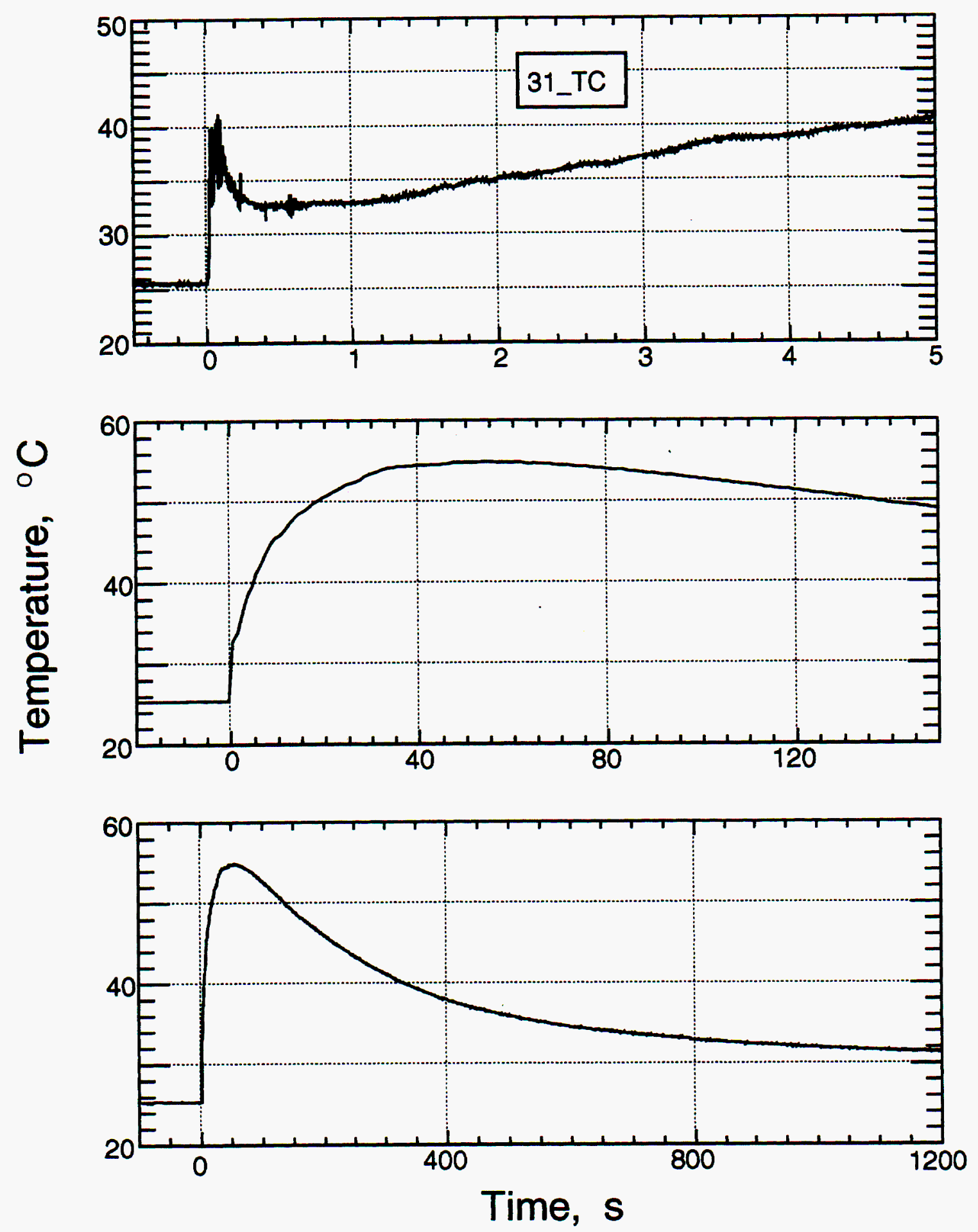

Figure 7 Temperature in the zero-room measured by the thermocouple mounted on the left rib about $2.3 \mathrm{~m}$ above the invert. 

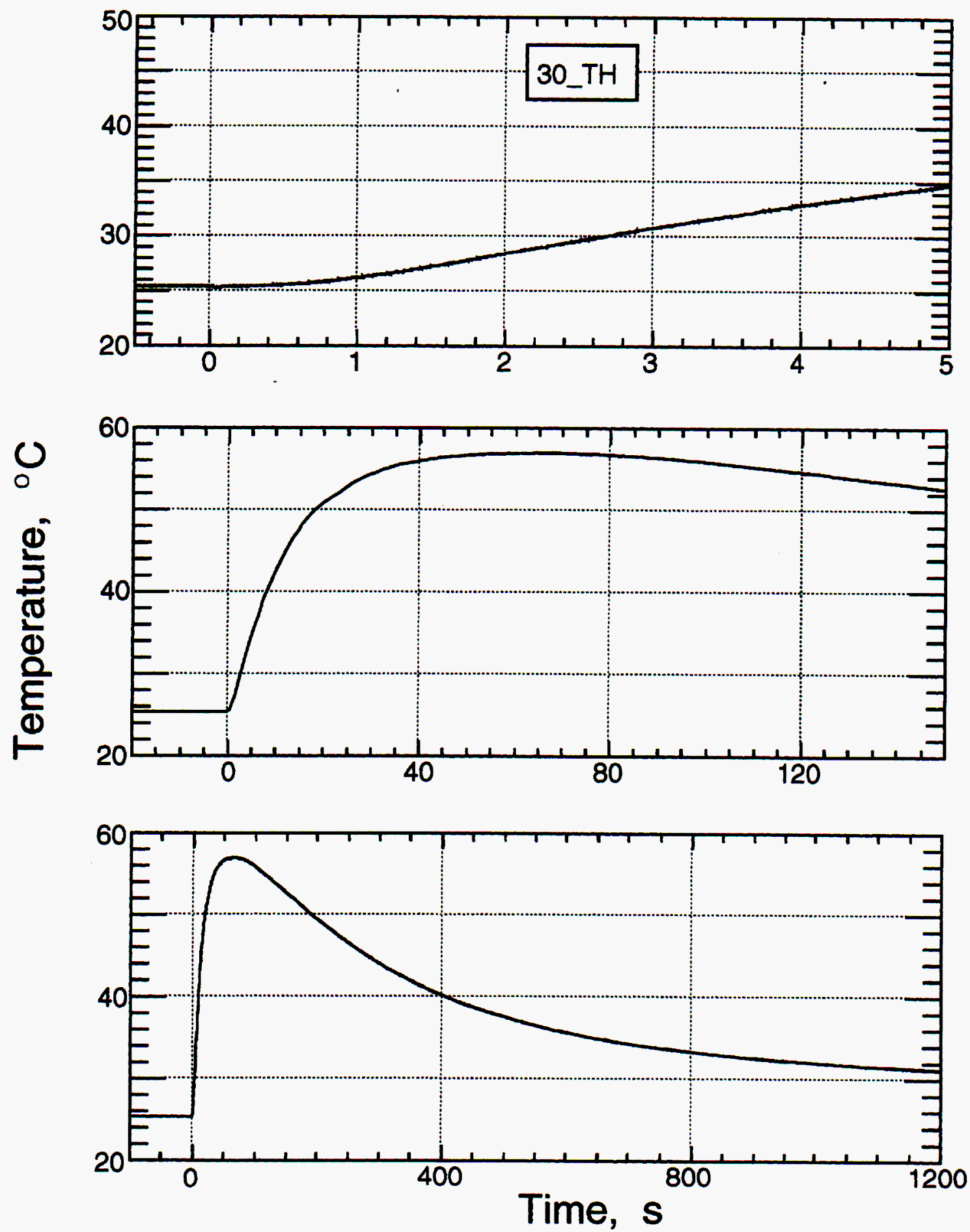

Figure 8 Temperature in the zero-room measured by the thermistor mounted on the left rib about $2.3 \mathrm{~m}$ above the invert. 


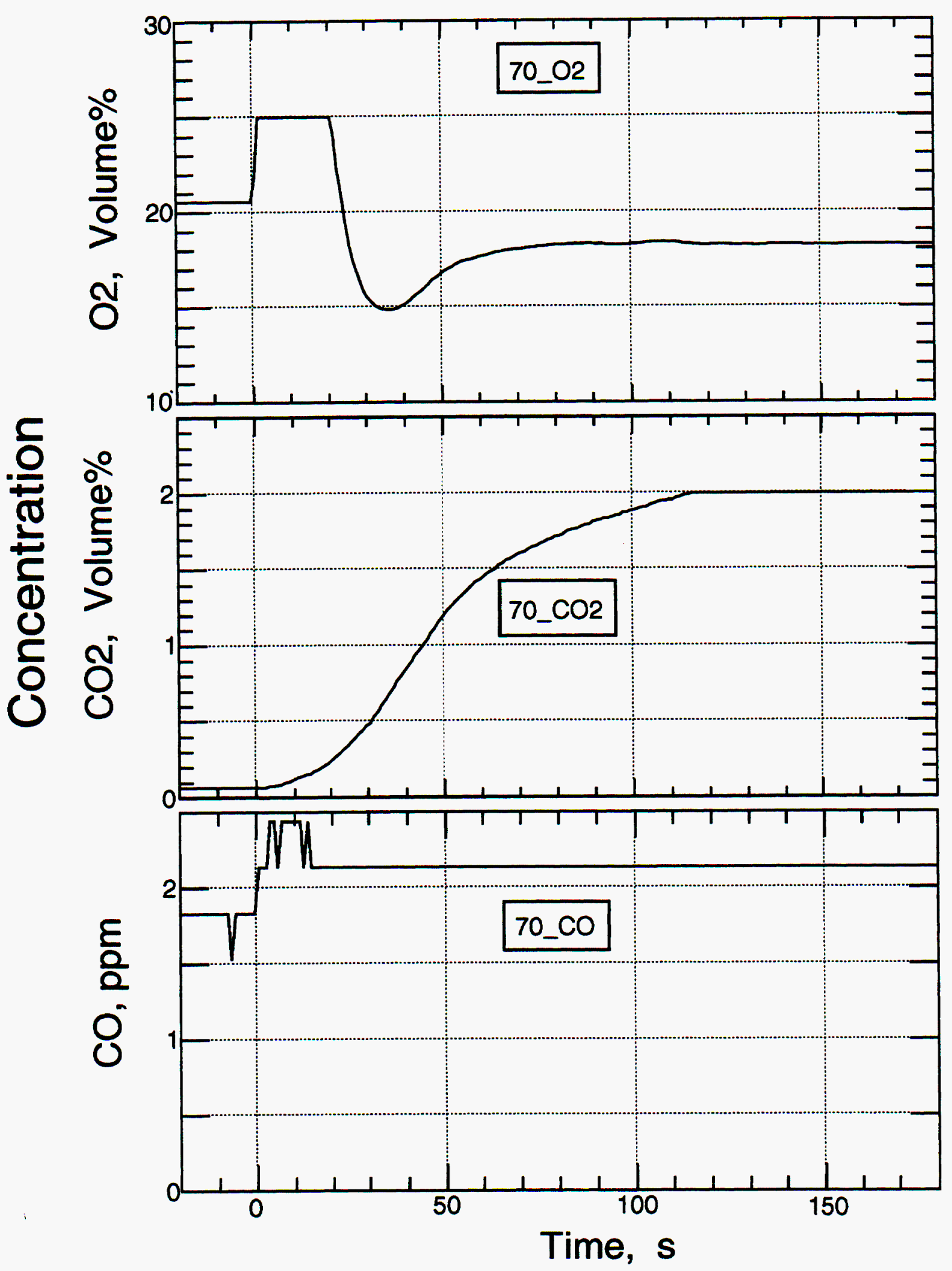

Figure 9 Gas composition of the zero-room. The CO transducer apparently failed at early time while the $\mathrm{O}_{2}$ sensor was affected by the detonation and did not recover until after $30 \mathrm{~s}$. The $\mathrm{CO}_{2}$ data are as expected. 


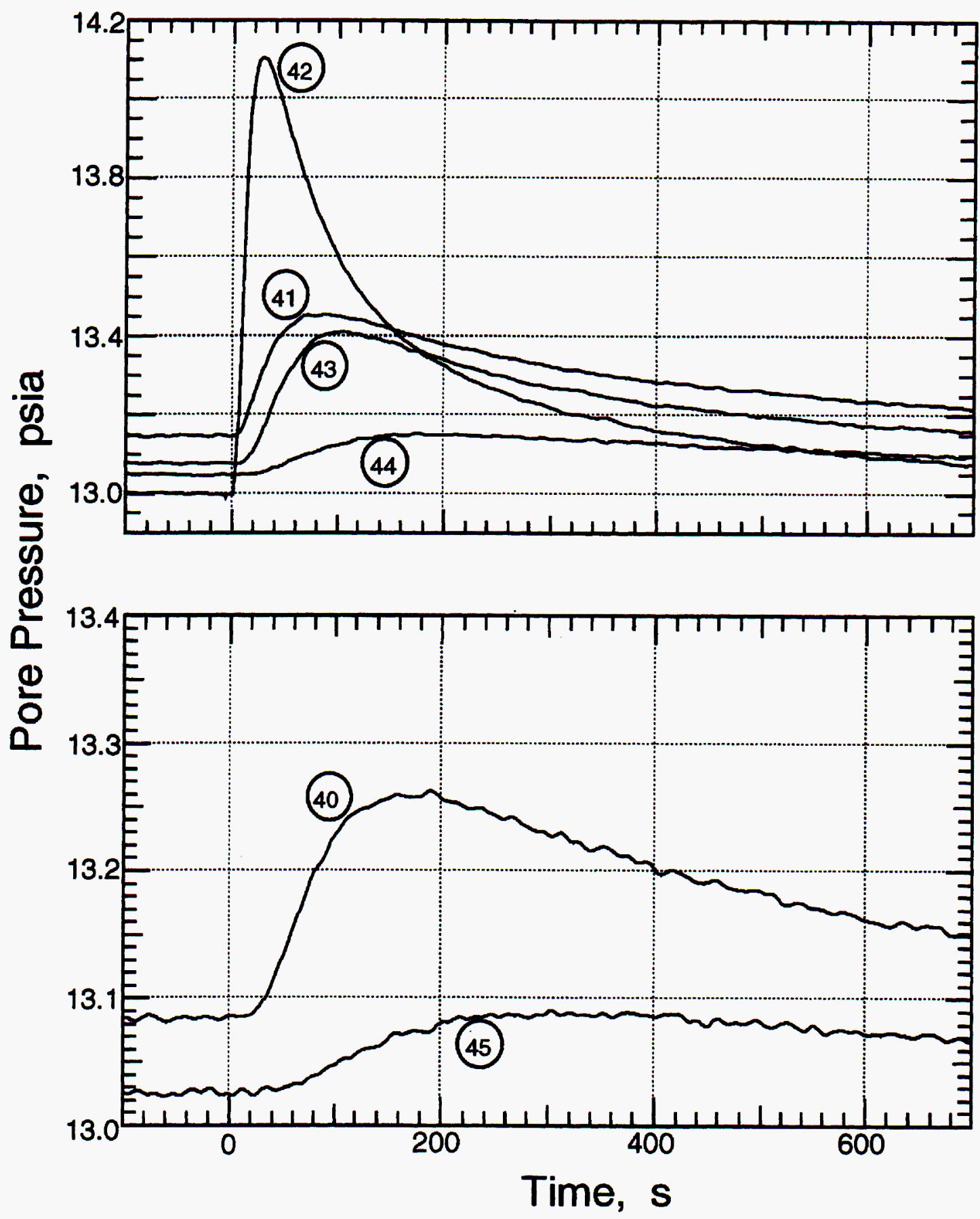

Figure 10 Pore pressure measured in the formation. Stations 41-44 were fielded in bore holes in the zero-room. Stations 40 and 45 were in bore holes from drift U1a.101 (station 40 was also used on the HOLOG experiment). 


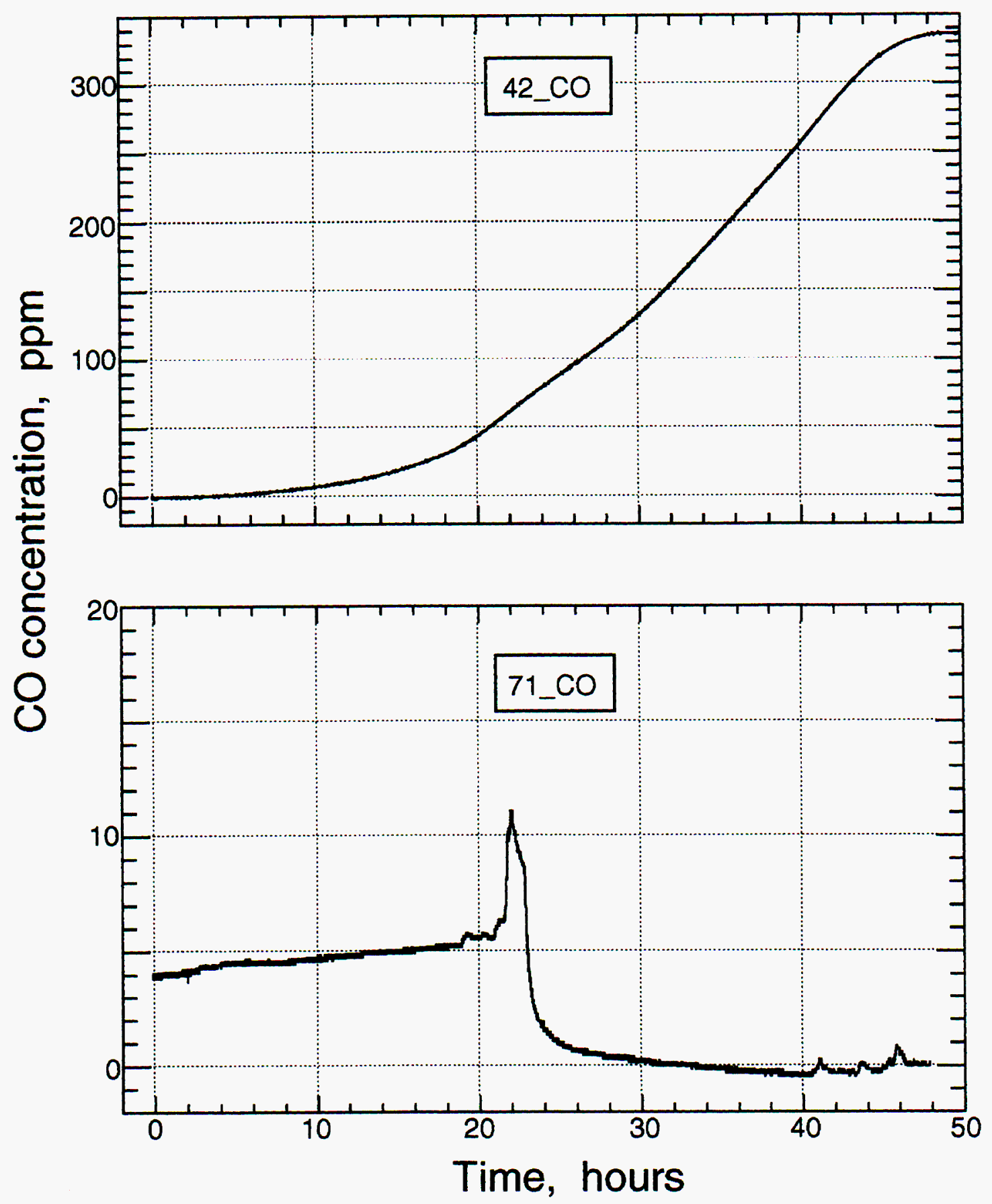

Figure 11 The first 50 hours of $\mathrm{CO}$ measured at stations 42 (in the formation) and 71 (in the U1a.101 drift). 


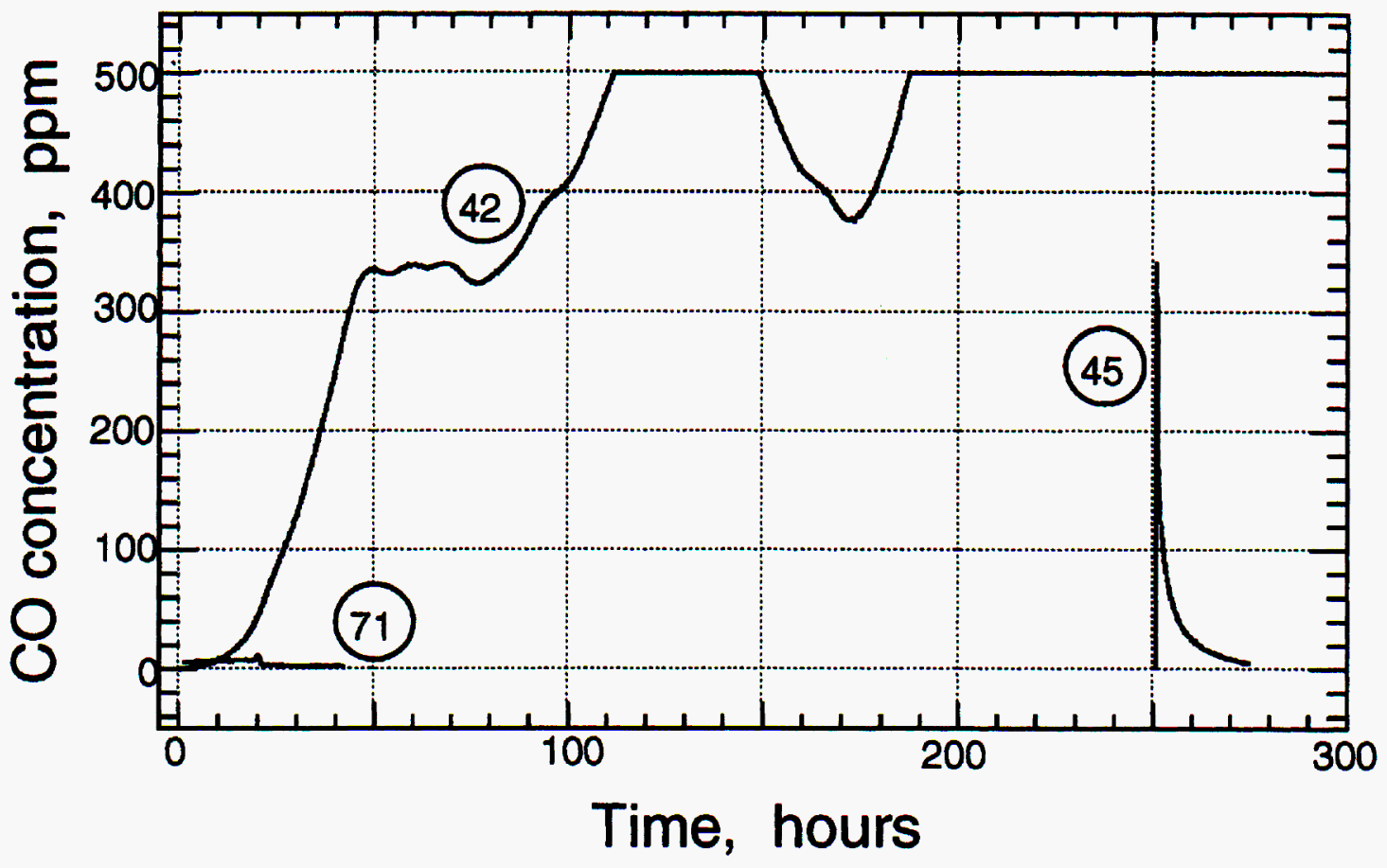

Figure 12 The full length of measurement of $\mathrm{CO}$ at stations 42,45 , and 71 . Station 45 did not report until about 10 days after the event when the drift was re-entered and a $\mathrm{CO}$ source was activated to test the function of station 45 . 

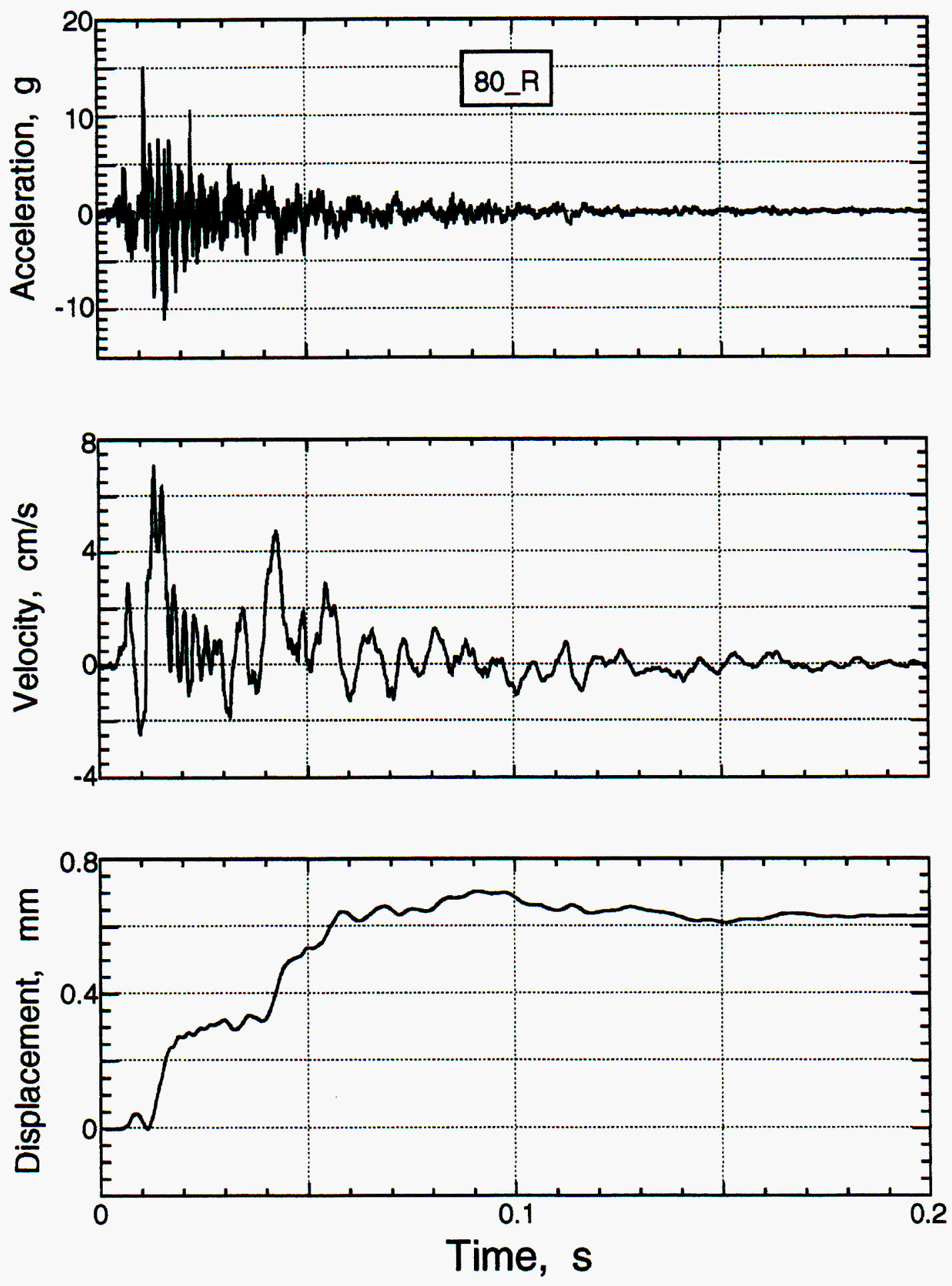

gure 13 Motion of the working point side of the barrier. 


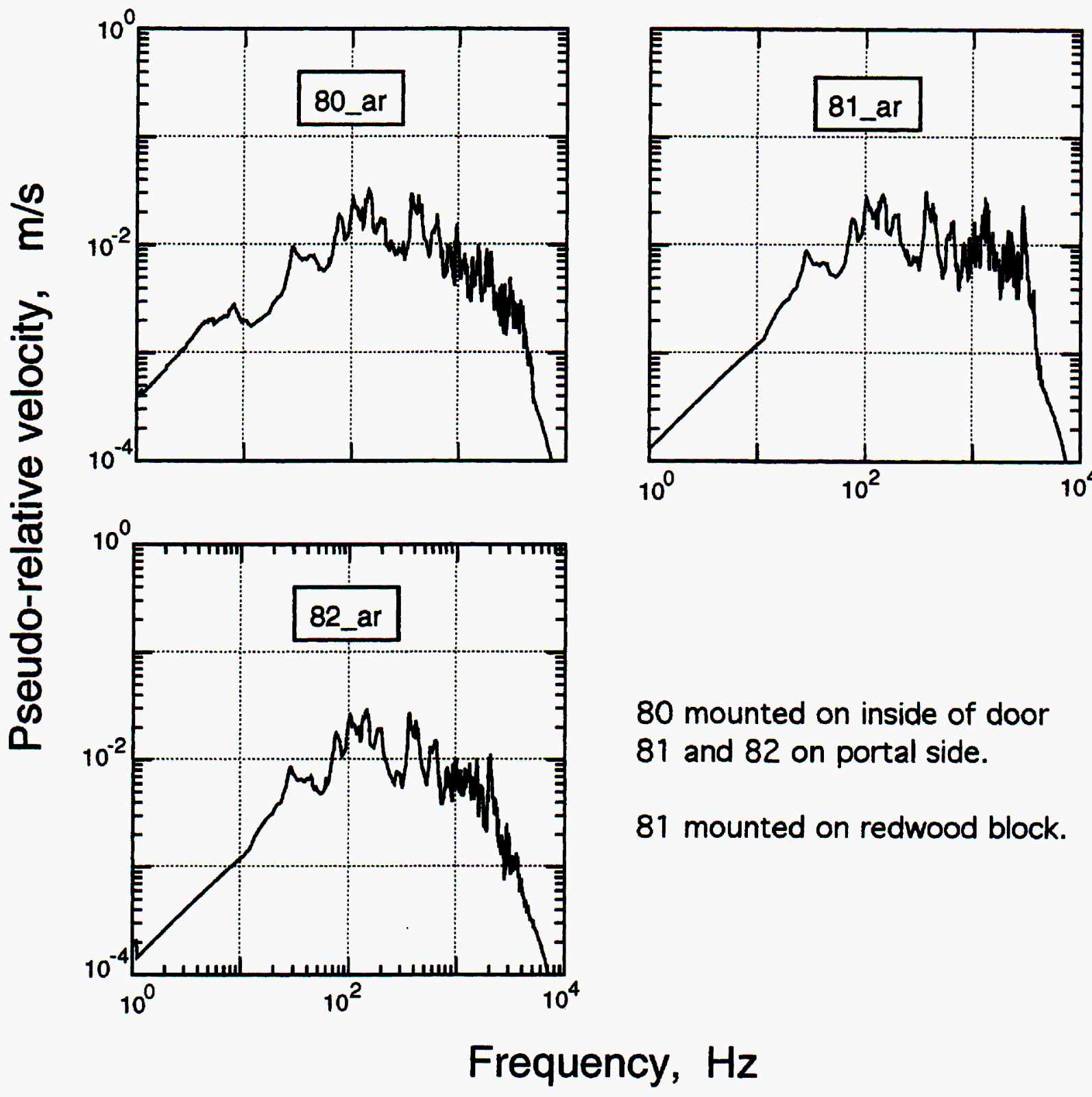

Figure 14 Spectra of the three radial motion stations. Note that the station on the working point side of the door $(80)$ has a higher amplitude at frequencies below $15 \mathrm{~Hz}$. Station 81 , mounted on the redwood block has two regions of high amplitude above $15 \mathrm{kHz}$ that are not seen in the other two stations. 


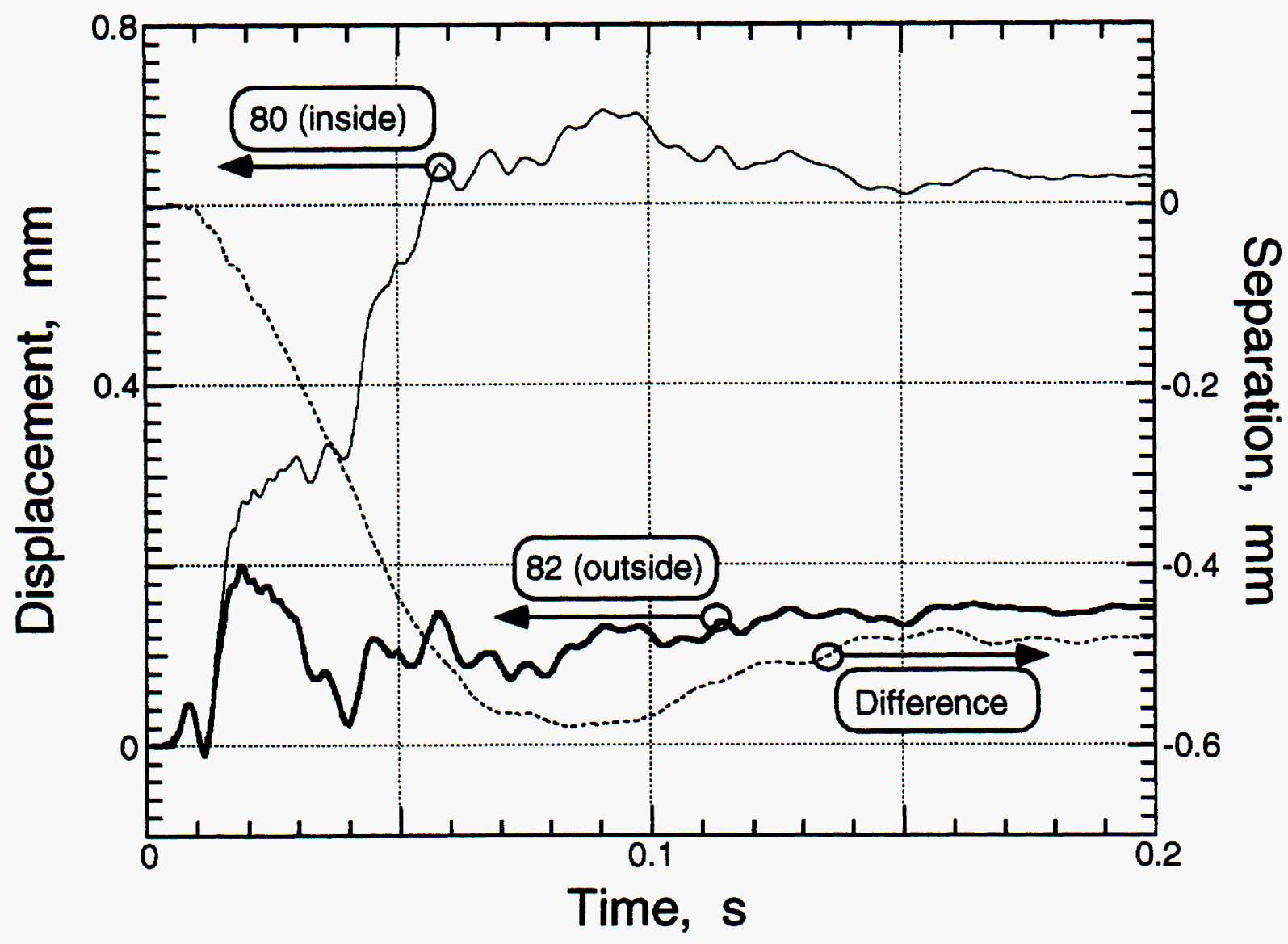

Figure 15 Displacement of both sides of the barrier and the numerical difference between the waveforms (the dashed line). 


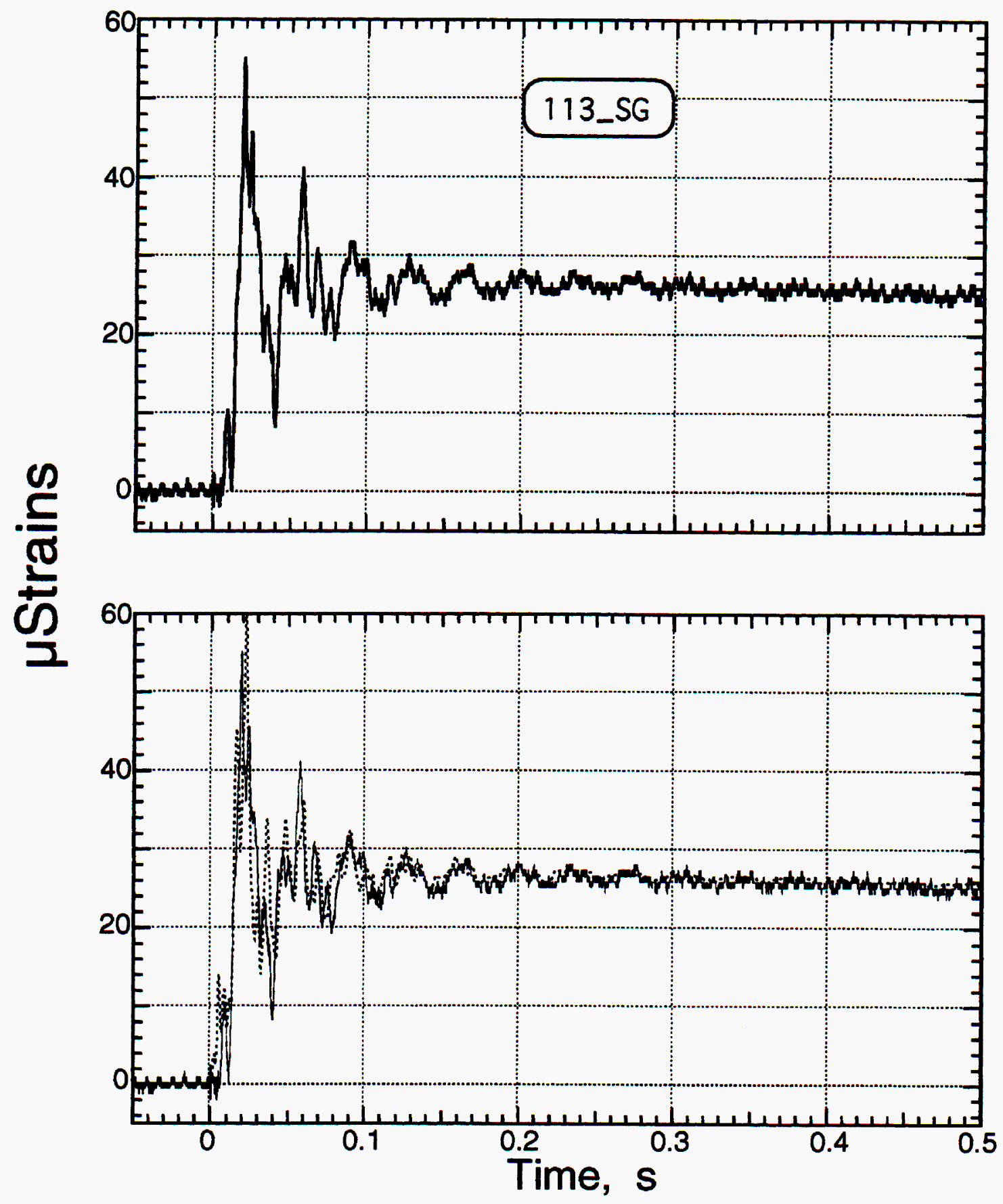

Figure 16 Upper plot: Strain of the center of the portal side of the barrier (station 113). Lower plot: data from station 113 overlain with the data from the quasi-static pressure transducer at station 11. The pressure data (dashed) were adjusted to be at zero amplitude before detonation and multiplied by a factor of 2.4 for presentation 

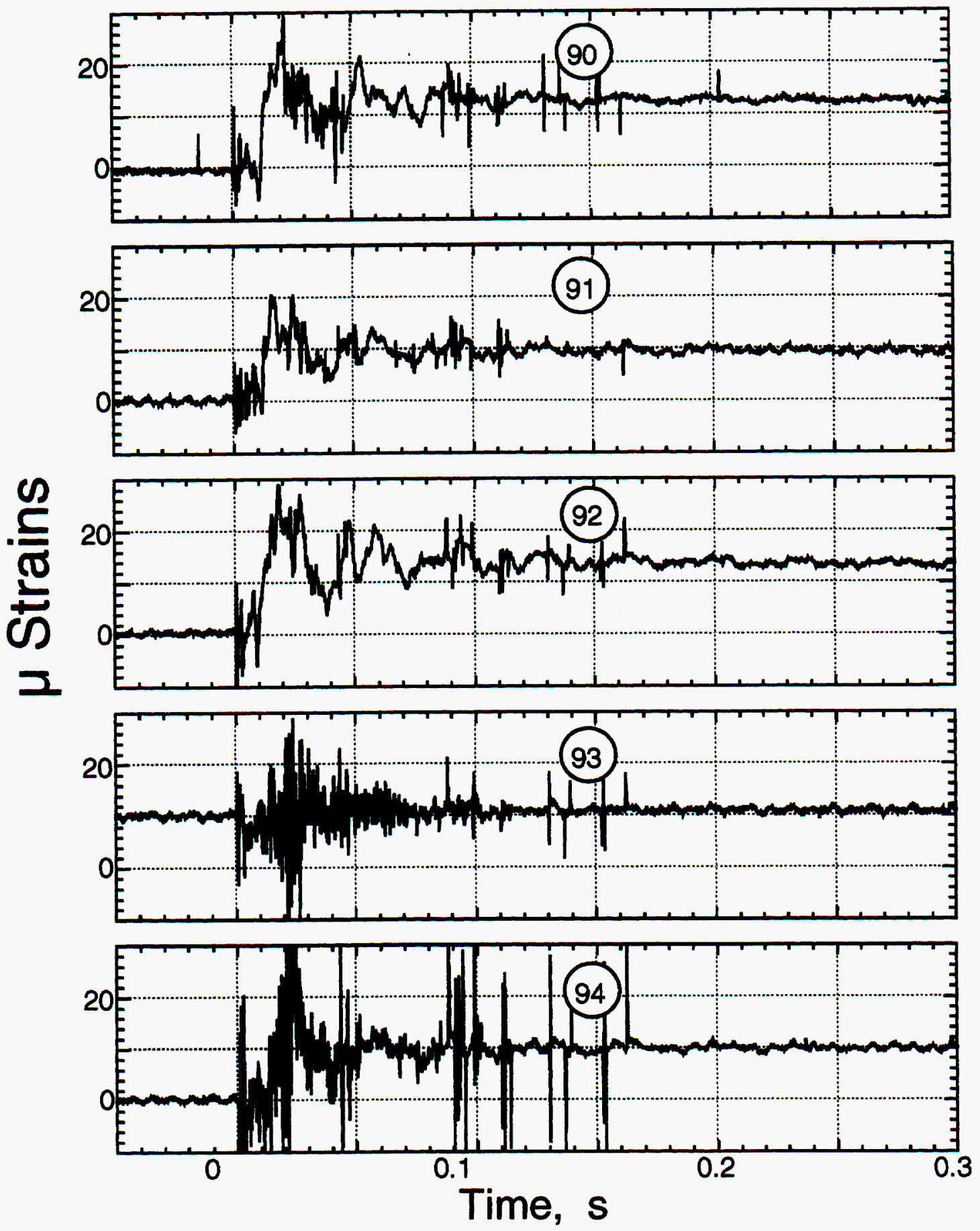

Figure 17 Embedment strain around the perimeter of the working point side of the barrier. 

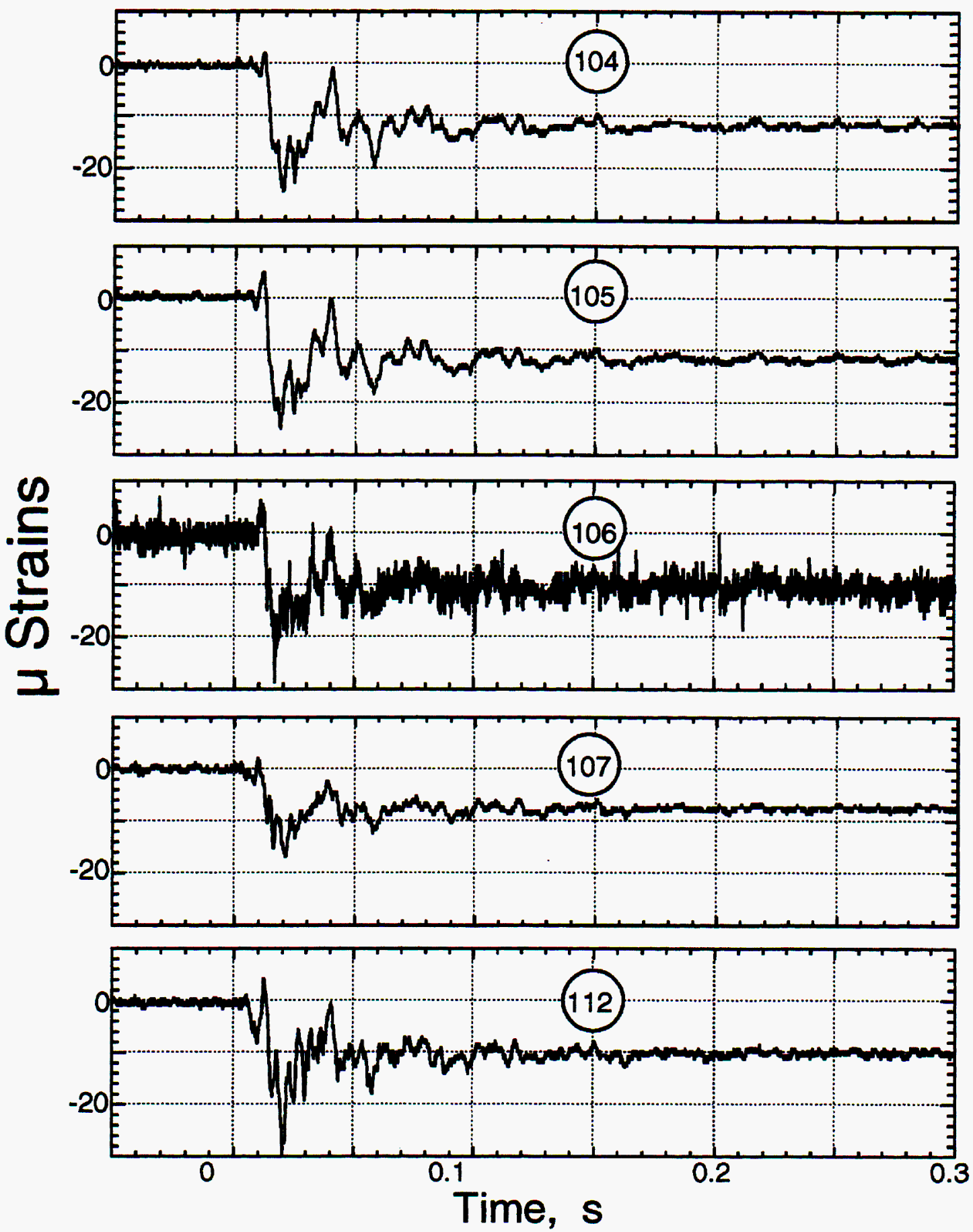

Figure 18 Selected strain measurements on the portal side of the barrier (part 1). 


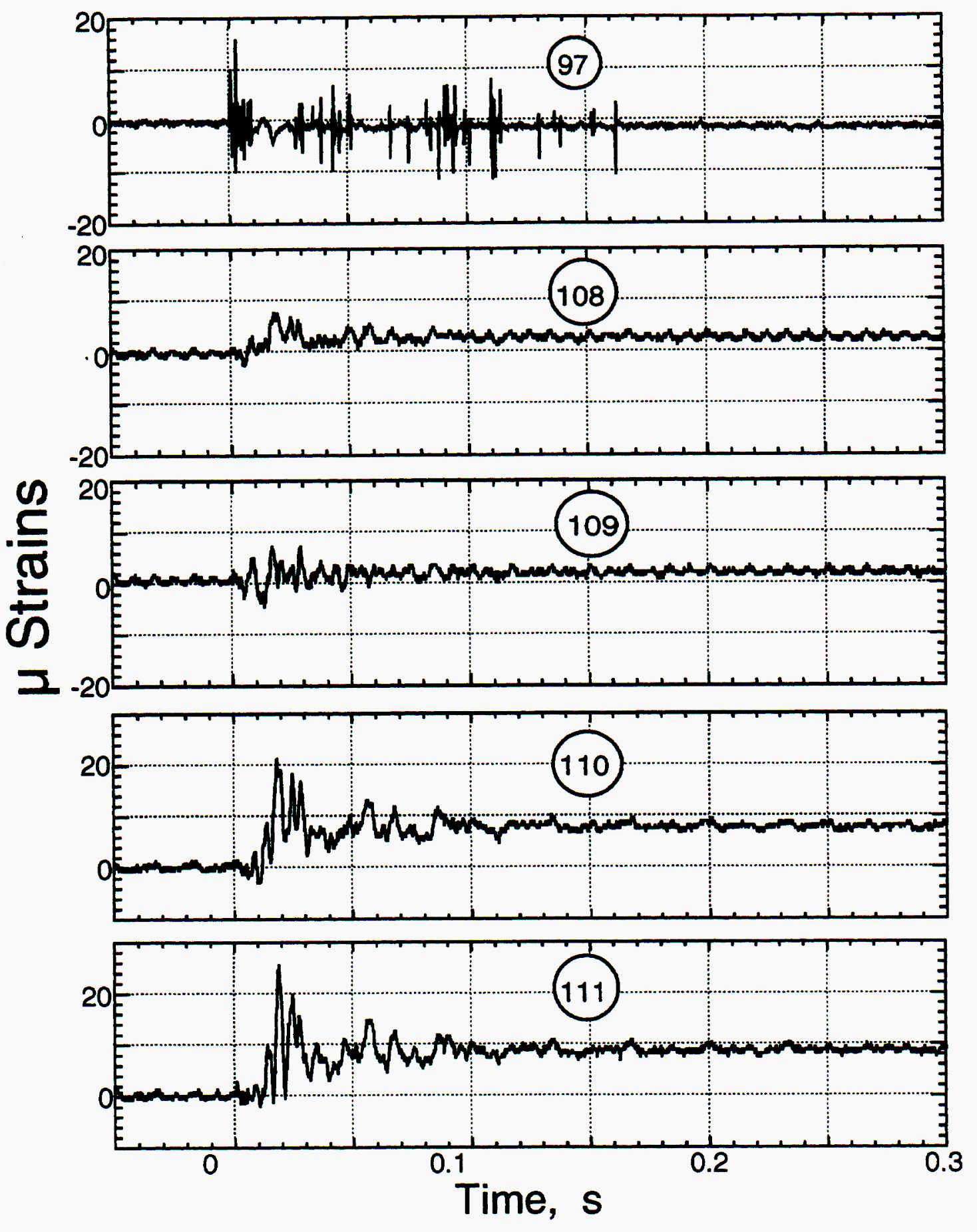

Figure 19 Selected strain measurements on the portal side of the barrier (part 2) and a representative of the embedment strain in the perimeter (station 97). 


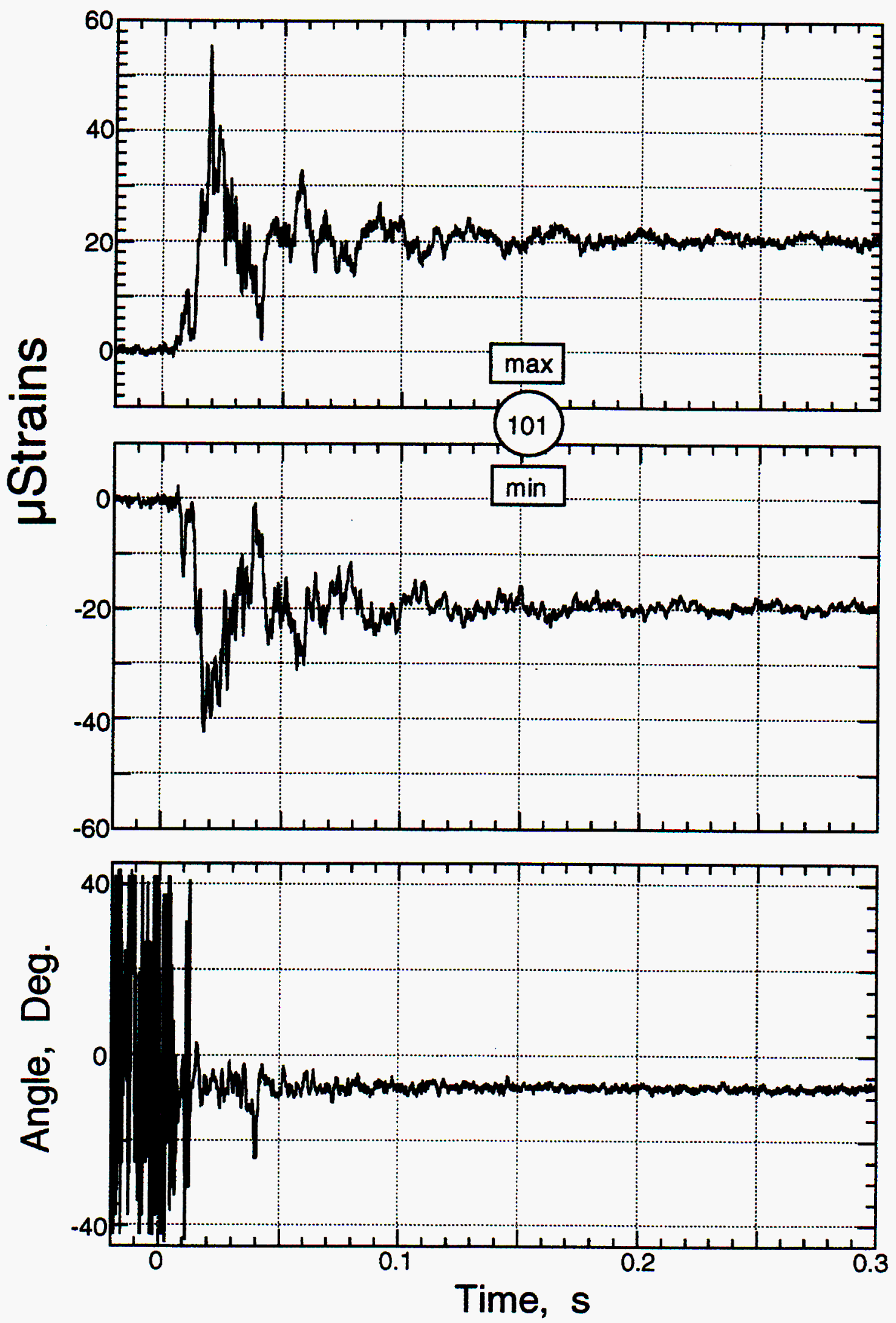

Figure 20 Maximum and minimum strains on the principal axis and the angle through which the strain ellipse was rotated from the transducer mounting. Station 101 was mounted near the center of the barrier at the column nearest the access port. 


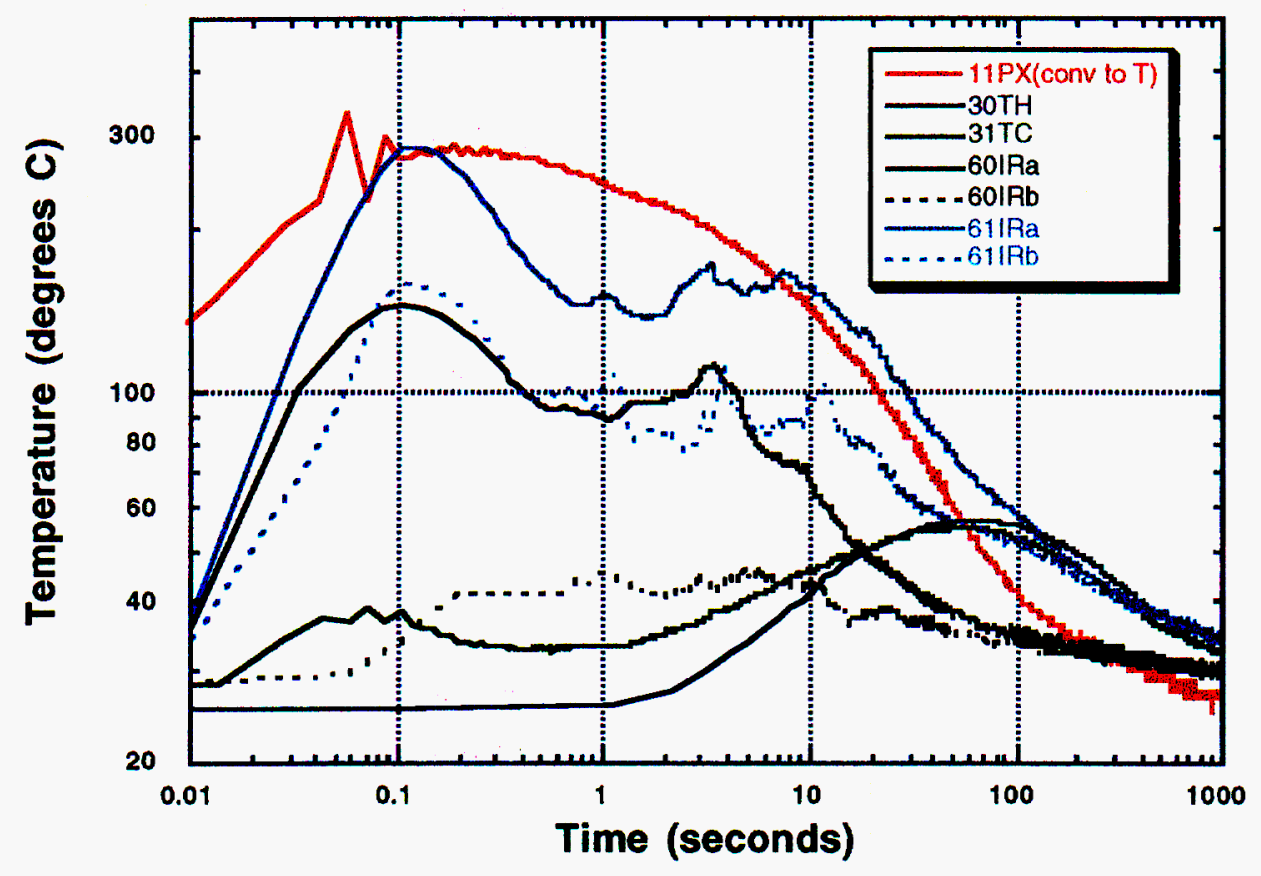

Figure 21 The four IR thermometers are shown with a temperature derived from the quasi-static pressure transducer, 10PX. In addition, temperatures from a thermistor, $30^{\mathrm{TH}}$, and from a fast thermocouple, 31TC, are shown. 


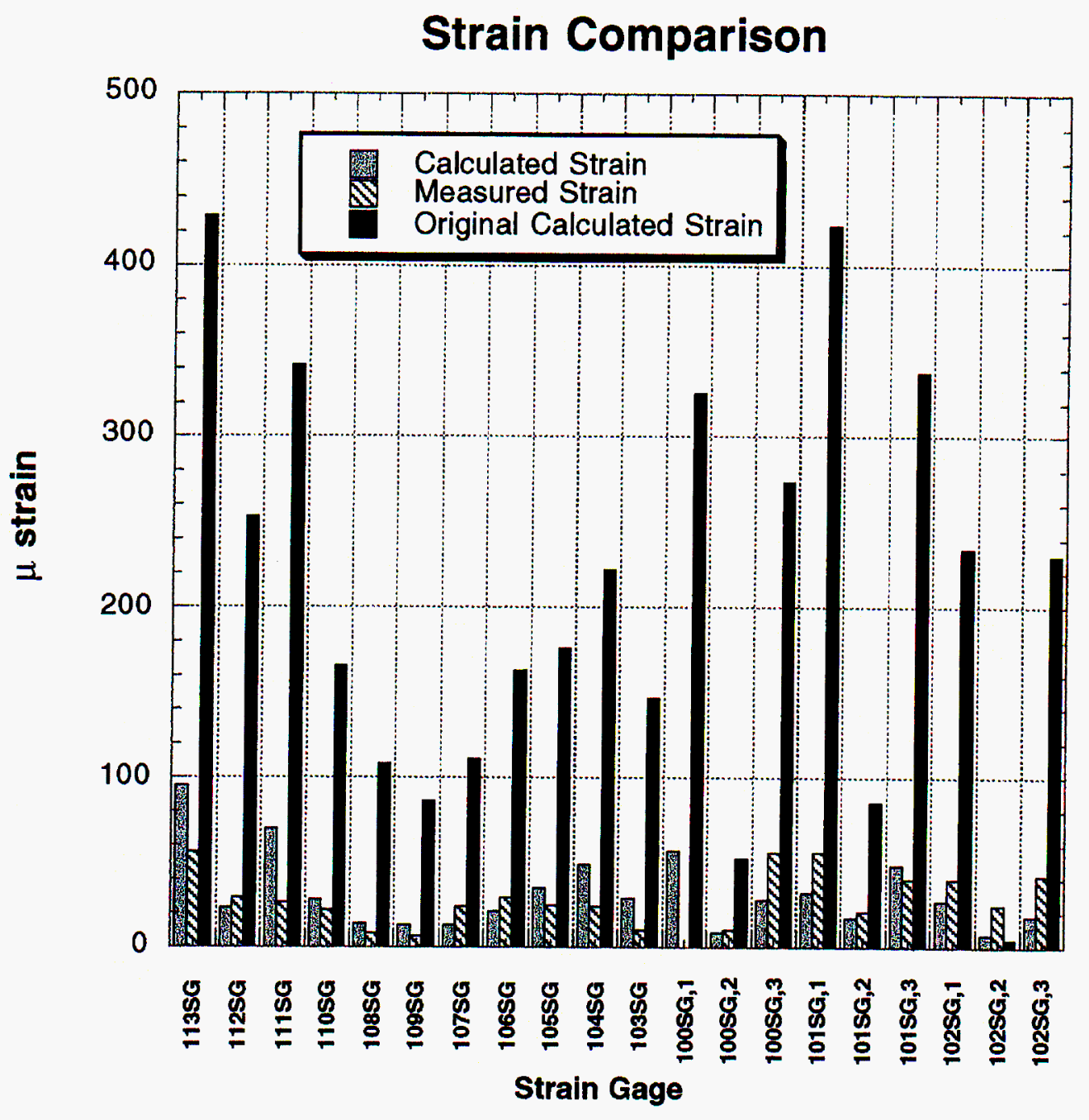

Figure 22 Strain comparison for original calculated strain, measured strain, and revised strain on the primary barrier 


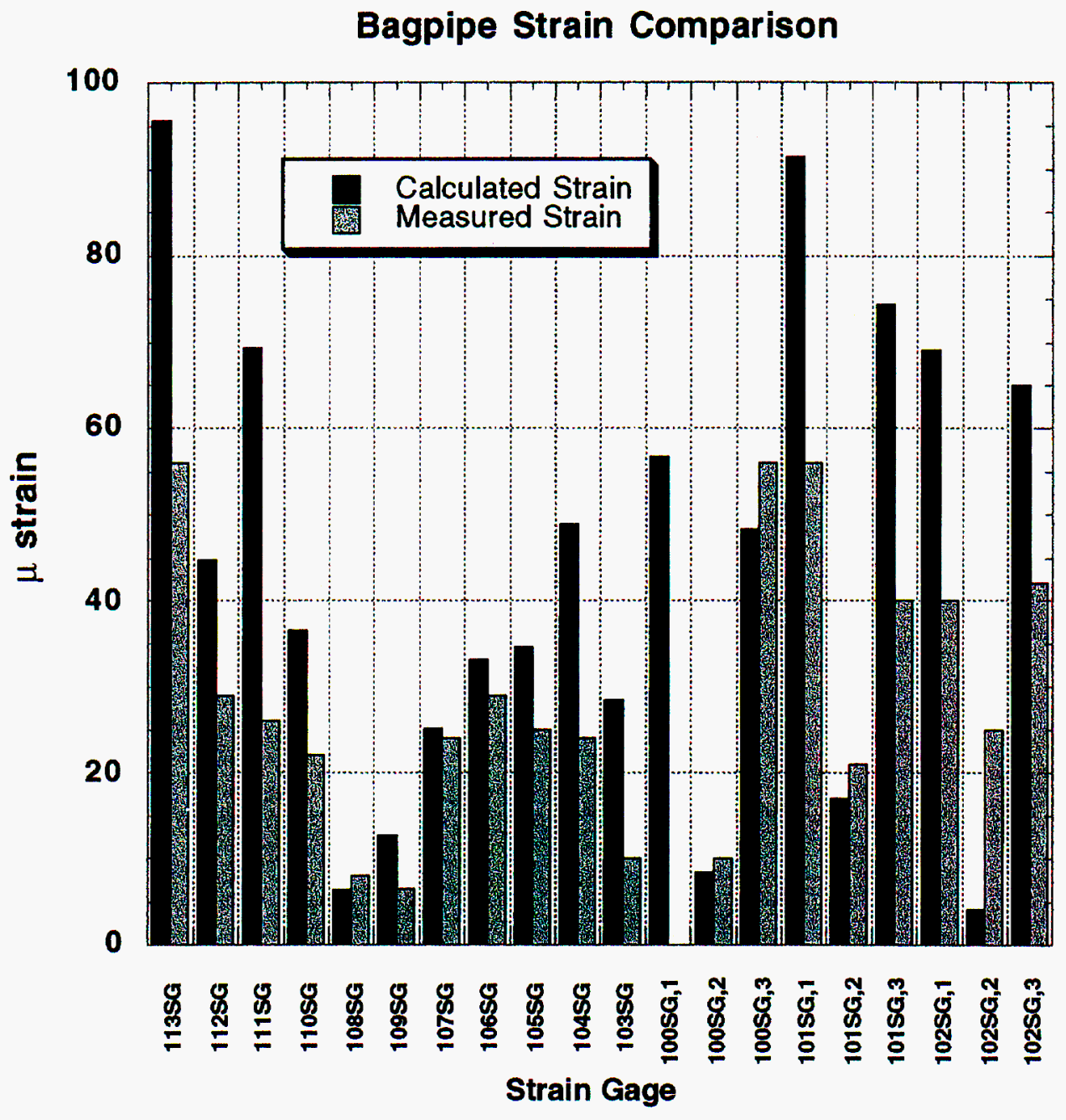

Figure 23 Strain comparison for measured strain and calculated strain on the primary barrier 


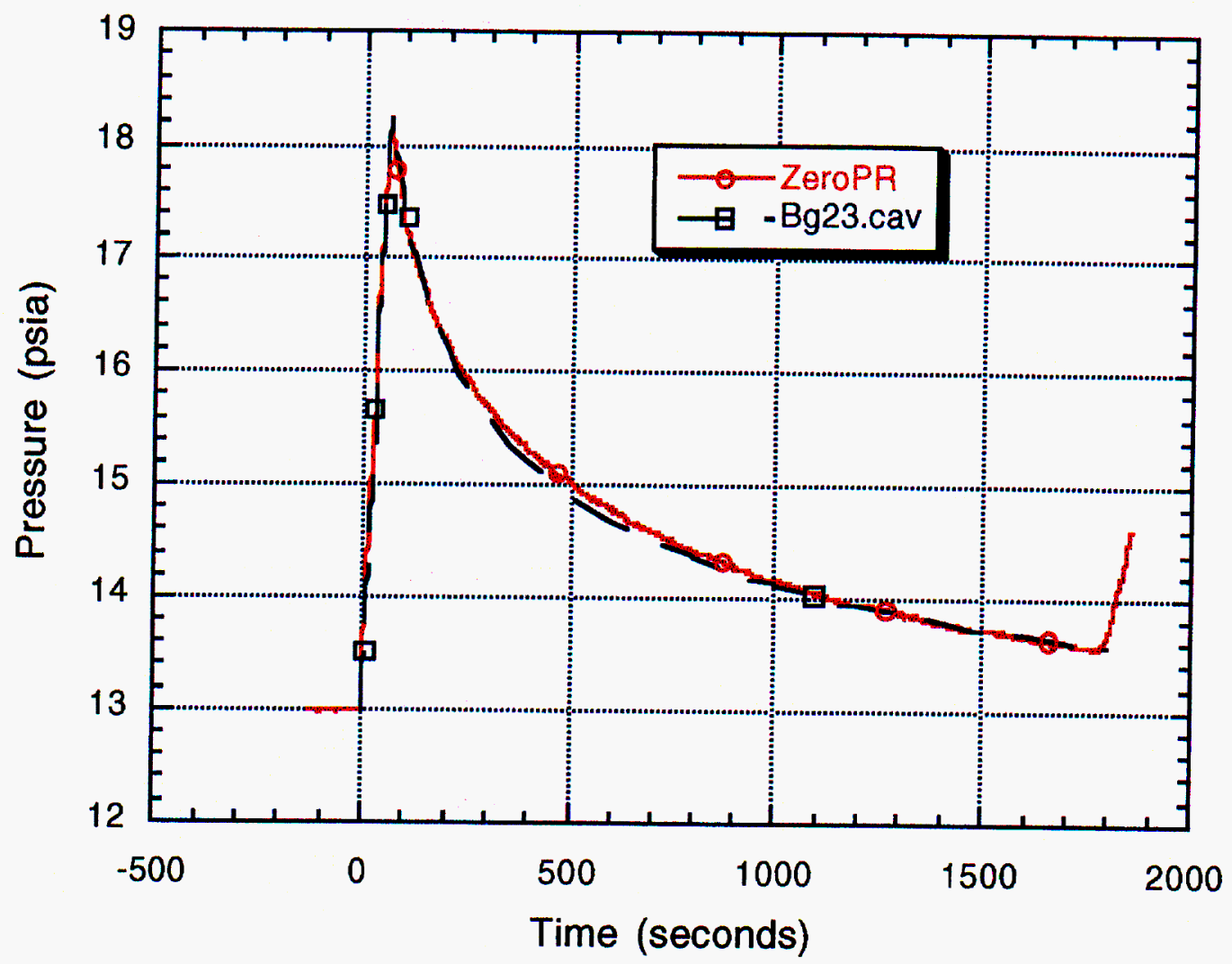

Figure 24 The zero-room pressure decay during final BAGPIPE primary barrier pressure test is compared with a calculated porous flow decay using the parameters of Table 1. 


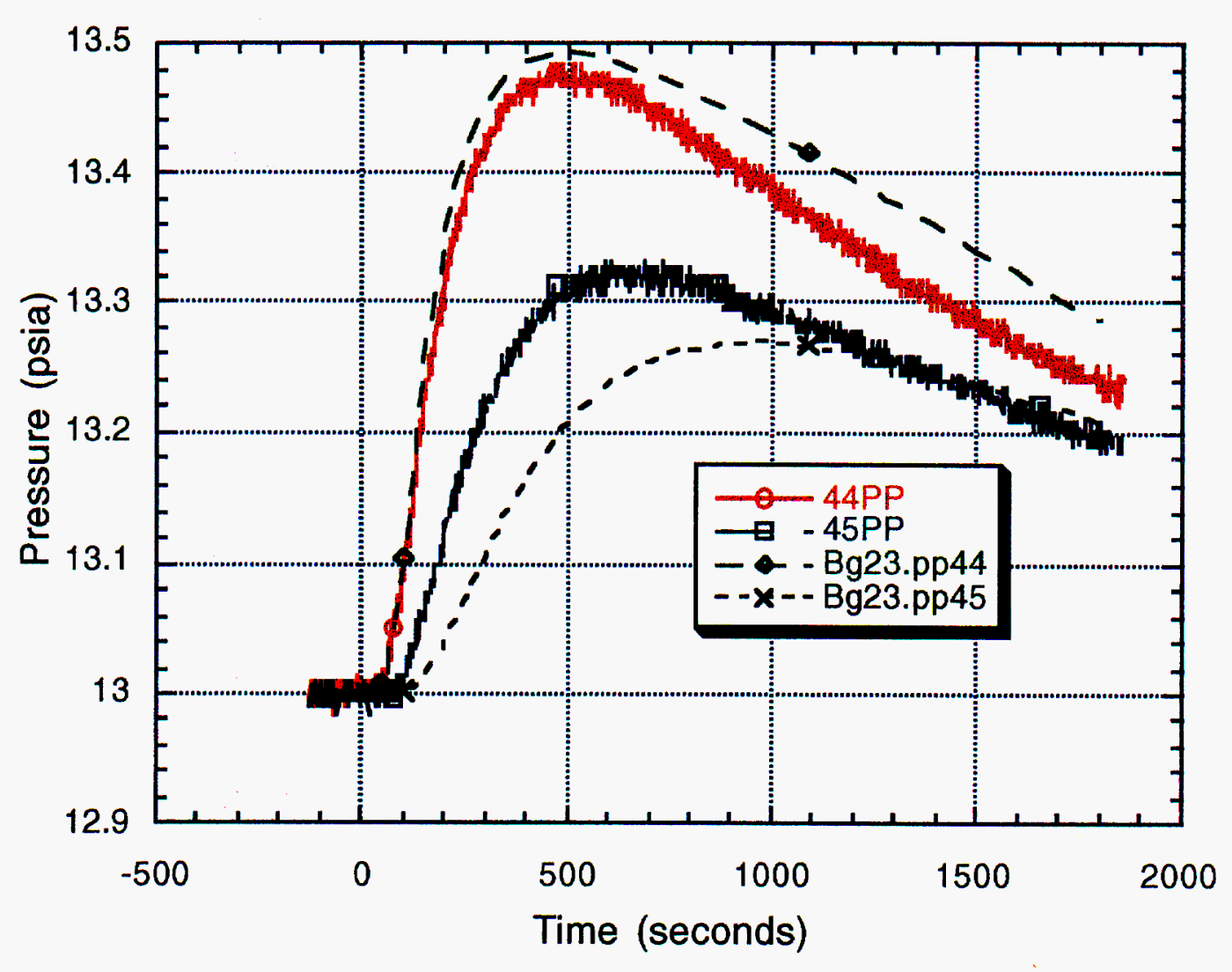

Figure 25 Pore pressures in the right rib of the zero-room during the BAGPIPE primary barrier pressure test are compared with the calculated porous flow pressures using the parameters of Table 1. 


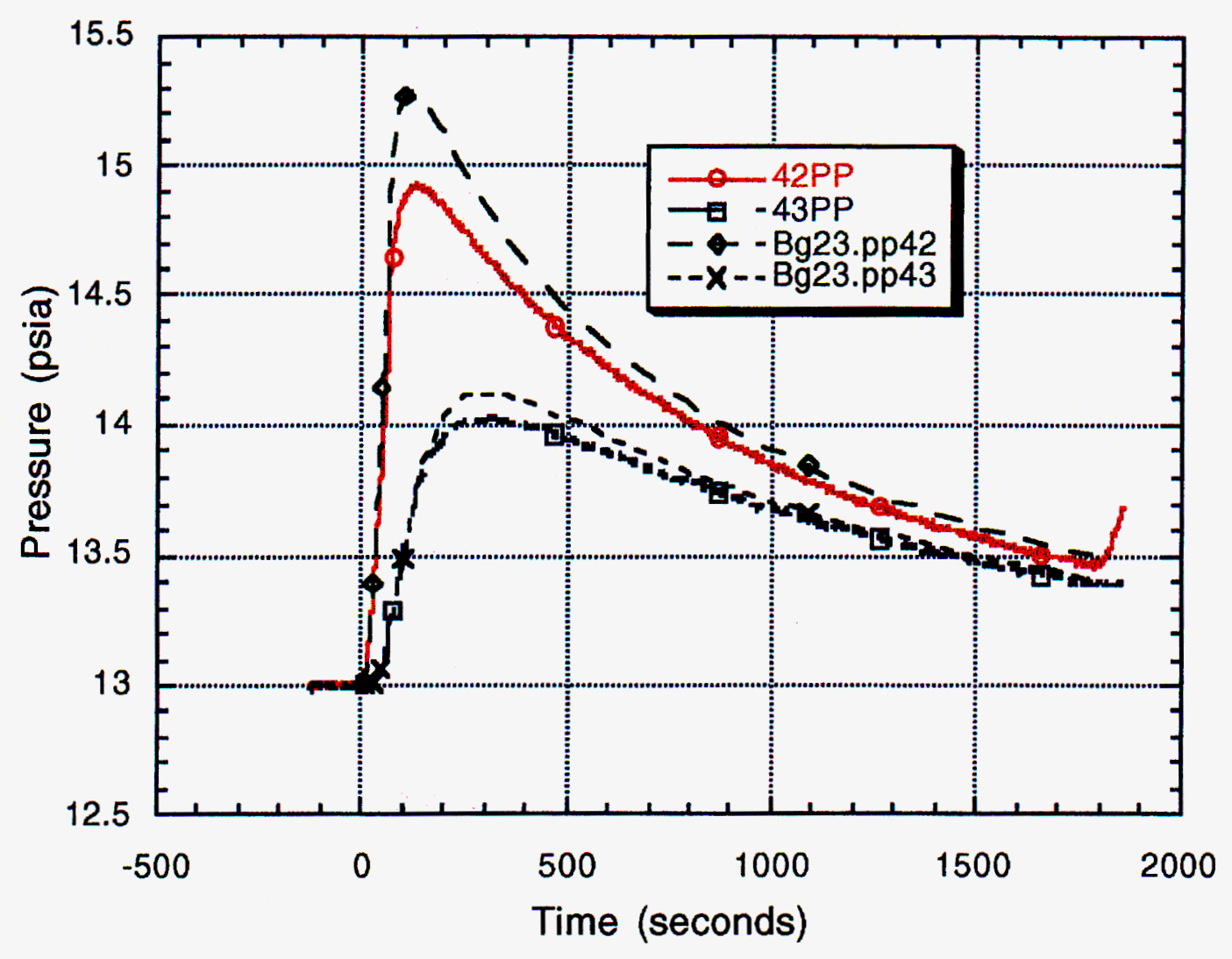

Figure 26 Pore pressures in the face of the zero-room during the BAGPIPE primary barrier pressure test are compared with the calculated porous flow pressures using the parameters of Table 1. 


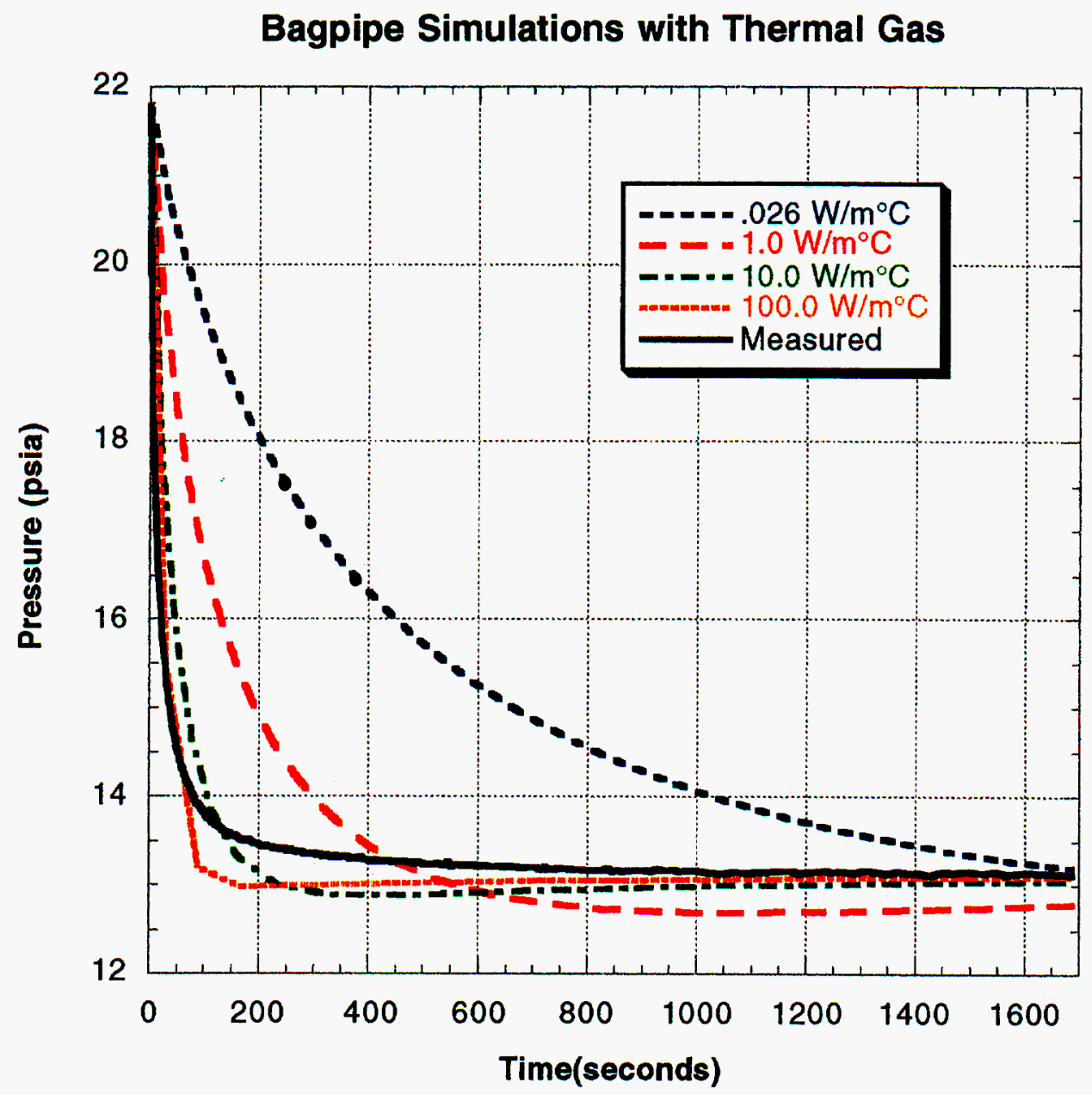

Figure 27 The pressure decay for thermal gas in the BAGPIPE zero-room for a range of thermal conductivities is compared to the measured pressure decay. The thermal conductivity of air is about $0.026 \mathrm{~W} / \mathrm{m}^{\circ} \mathrm{C}$ and the thermal conductivity of iron is about $84 \mathrm{~W} / \mathrm{m}{ }^{\circ} \mathrm{C}$. 


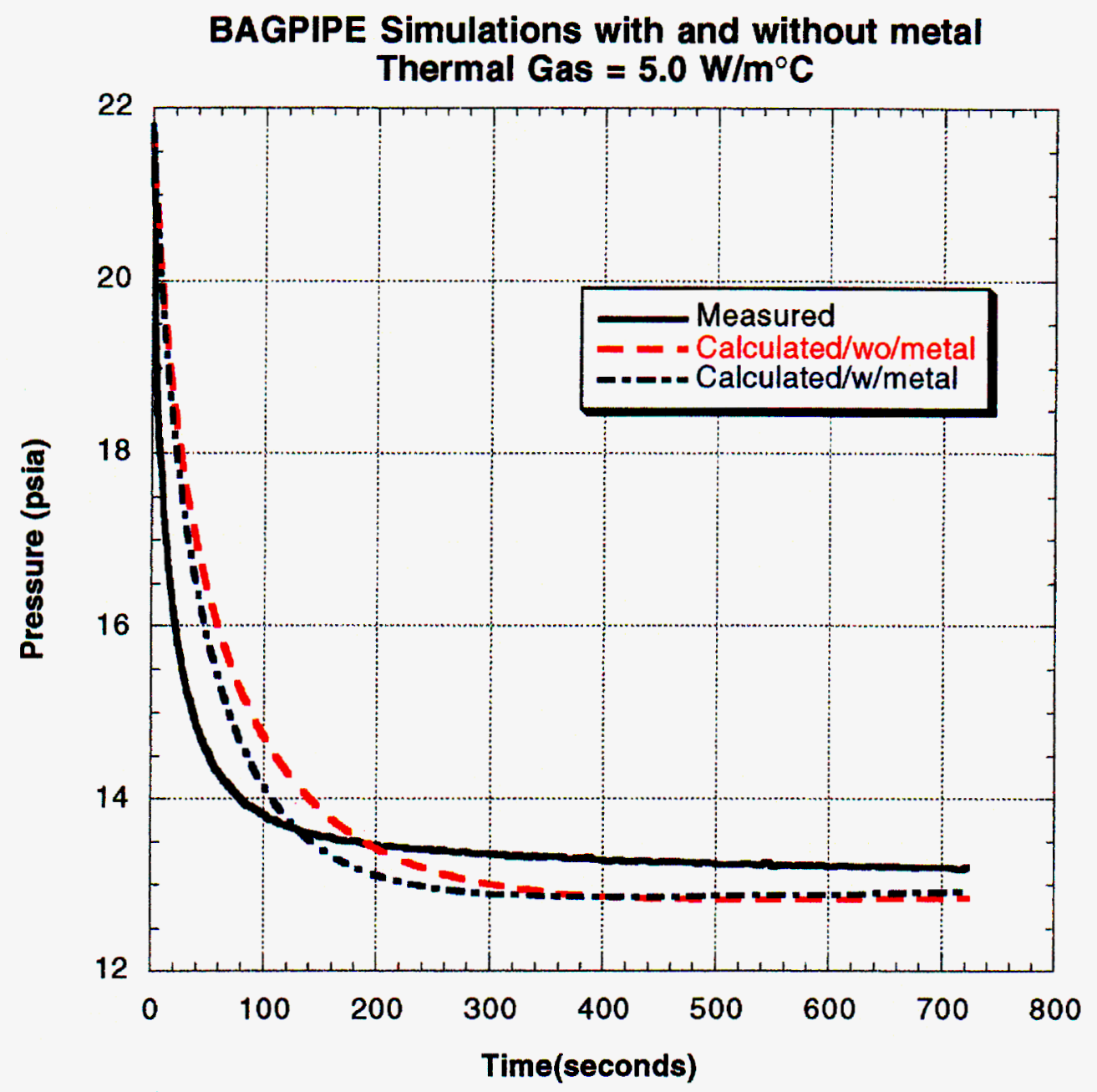

Figure 28 The pressure decay in the BAGPIPE zero-room with an iron surface area which approximates the surface area actually present throughout the zero-room. The metal surface does reduce the pressure faster but does not change the results significantly. 
Appendix A

BAGPIPE Physics Instrumentation Plan 
Bechtel Nevada

Interoffice Memorandum

To:

B. W. Bellow

From: $\quad$ M. Bridenburg

Special Measurements \& Support, 295-0652
Date: August 3, 1998

No.: 2133-BB-98-0017

Subject: BAGPIPE PHYSICS INSTRUMENTATION PLAN

Project No. N/A

Enclosed is the BAGPIPE Physics Instrumentation Plan Revision 0. Please contact me at (702) $295-0652$ is you have any questions.

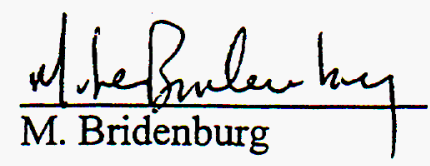

MB:jc

Subject Code: DEF 16

Enclosure: as stated

Norm Burktiard Marl Cove L-999

(a) llal

Two Stalls Mut cole $\lfloor-22 \mid$

43 


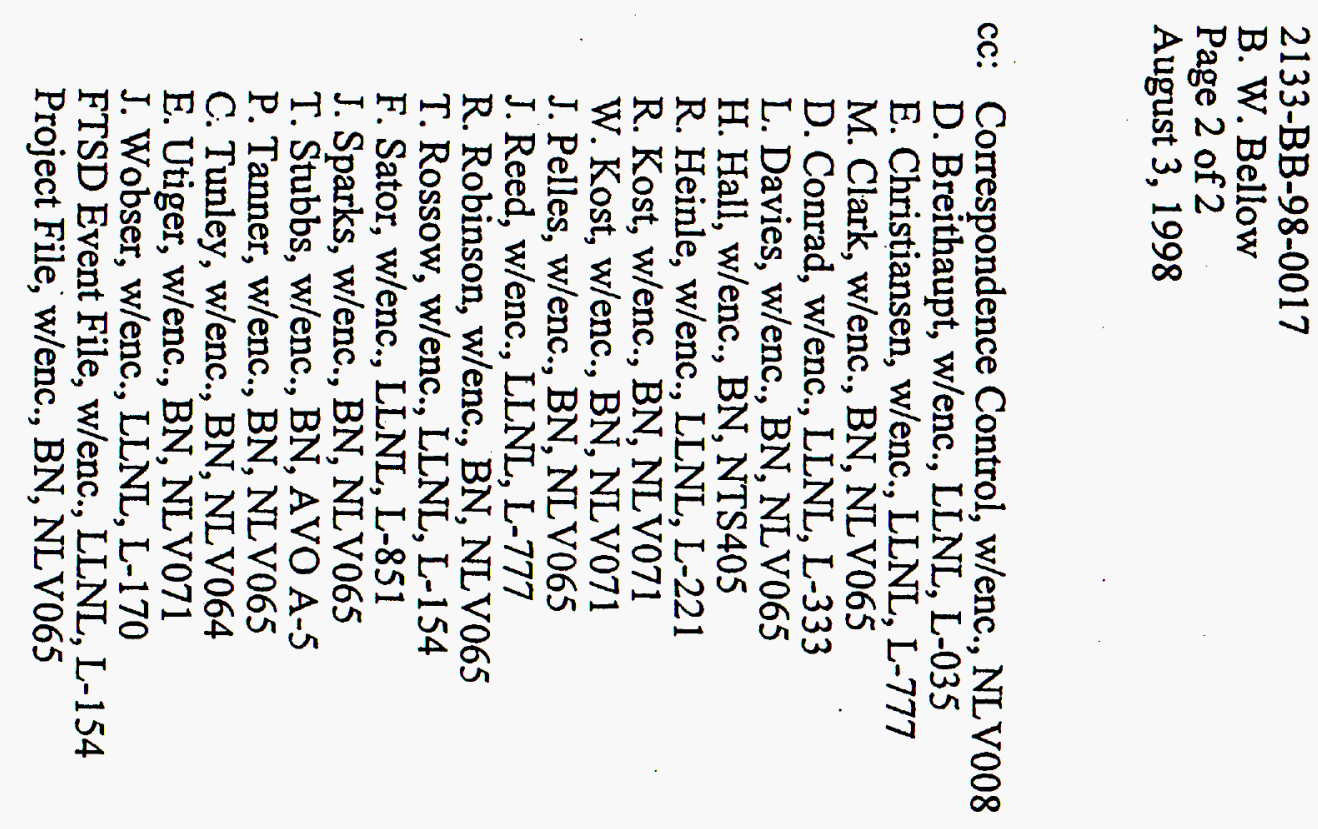




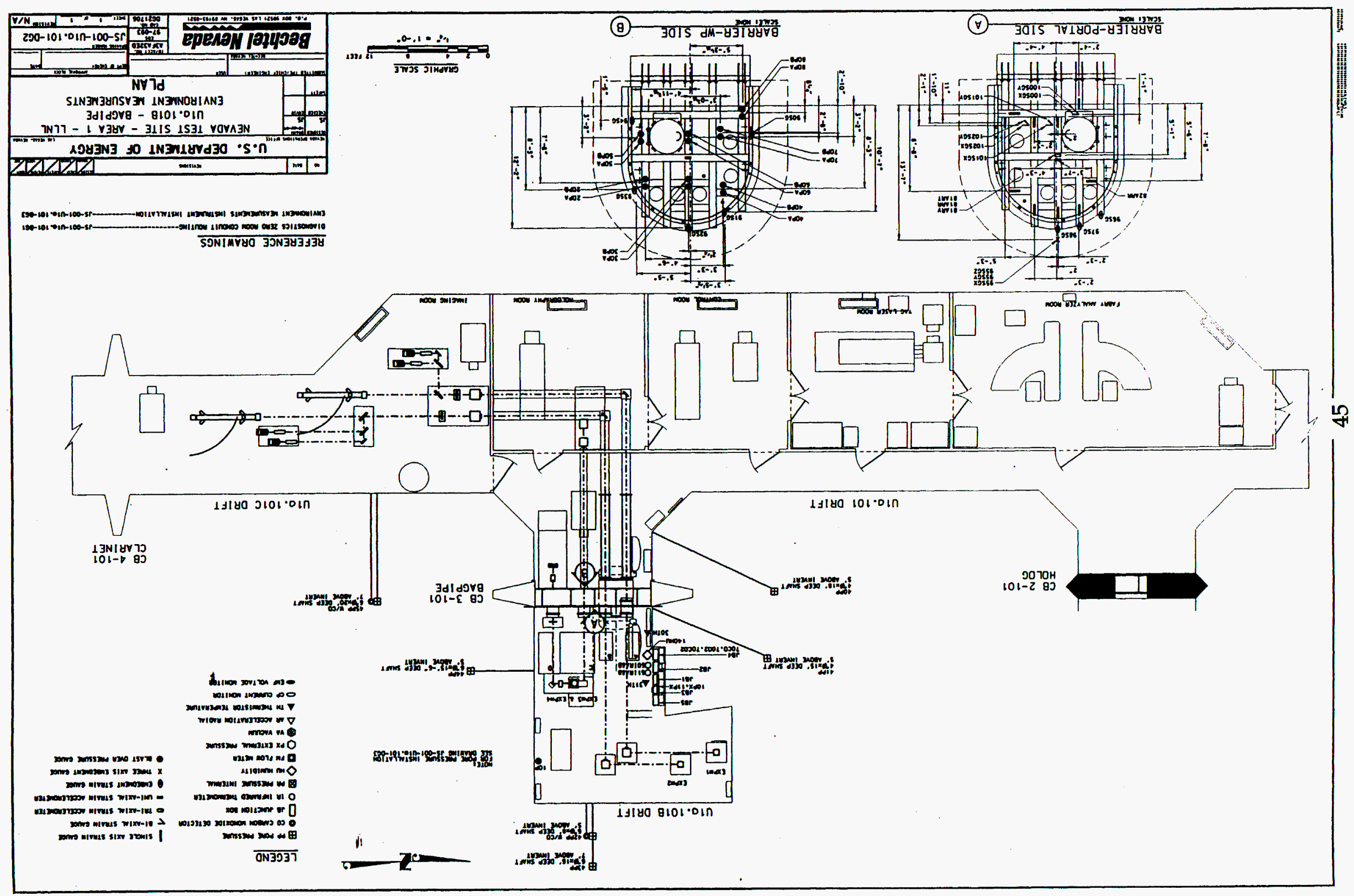




\section{Bechtel Nevada}

PHYSICS/INSTRUMENTATION PLAN

Prepared by:

PHY. R. HEINLE
Page 1 of 11

Rev. 3

Date Sept 23, 1998 TRAILER_Alcove

West Users

EVENT BAGPIPE, Ula.101b S.E. B. BELLOW/M. BRIDENBURG ,

\begin{tabular}{|c|c|c|c|c|c|c|c|c|c|c|c|c|}
\hline \multirow{2}{*}{$\begin{array}{l}\mathbf{S} \\
\mathbf{T} \\
\mathrm{A} \\
\mathrm{T} \\
1 \\
\mathrm{O} \\
\mathrm{N}\end{array}$} & \multirow[b]{2}{*}{ LOCATION } & \multirow[b]{2}{*}{ CHANNEL } & \multirow[b]{2}{*}{$\begin{array}{l}\text { XDUCER } \\
\text { MFGR \& } \\
\text { MODEL }\end{array}$} & \multirow[b]{2}{*}{$\begin{array}{c}\text { SERIAL } \\
\text { NUMBER }\end{array}$} & \multirow[b]{2}{*}{$\begin{array}{l}\text { XDUCER } \\
\text { RANGE }\end{array}$} & \multirow[b]{2}{*}{$\begin{array}{l}\text { OPERATE } \\
\text { RANGE }\end{array}$} & \multirow[b]{2}{*}{$\begin{array}{l}\text { SYSTEM } \\
\text { RANGE }\end{array}$} & \multirow[b]{2}{*}{$\begin{array}{c}\text { FULL } \\
\text { SCALE } \\
\text { VOLTAGE }\end{array}$} & \multicolumn{2}{|c|}{ CAL STEPS } & \multicolumn{2}{|c|}{ RECORDING } \\
\hline & & & & & & & & & LO & $\mathrm{HI}$ & $\begin{array}{l}\text { MERS / Filter Ch. } \\
\text { Samp. Rate, } F_{c}\end{array}$ & $\begin{array}{c}\text { SMIDS } \\
\text { (system } \\
\text { slot / } \\
\text { channel) }\end{array}$ \\
\hline 1 & Right Rib & $10 P$ & $\begin{array}{c}\text { PCB } \\
113 A 26\end{array}$ & 9998 & 500psig & 240psig & 300psig & $5 \mathrm{~V}$ & $1 \mathrm{~V}$ & $4 V$ & $\begin{array}{c}1 / 0 \\
20 \mathrm{kS} / \mathrm{s}, 10 \mathrm{kHz}\end{array}$ & \\
\hline \multirow[t]{2}{*}{2} & $\begin{array}{l}\text { Barrier } \\
\text { WP Side }\end{array}$ & $20 \mathrm{~Pa}$ & $\begin{array}{c}\text { PCB } \\
113 A 26\end{array}$ & 9999 & 500psig & 200psig & 250psig & $5 \mathrm{~V}$ & 1V & $4 V$ & $\begin{array}{c}2 / 1 \\
20 \mathrm{kS} / \mathrm{s}, 10 \mathrm{kHz}\end{array}$ & \\
\hline & $\begin{array}{c}\text { Barrier } \\
\text { WP Side }\end{array}$ & $2 \mathrm{OPb}$ & $\begin{array}{c}\text { PCB } \\
113 \mathrm{~A} 26\end{array}$ & 10000 & 500psig & 200psig & 250psig & $5 \mathrm{~V}$ & 1V & $4 V$ & $\begin{array}{c}3 / 2 \\
20 \mathrm{kS} / \mathrm{s}, 10 \mathrm{kHz}\end{array}$ & \\
\hline \multirow[t]{2}{*}{3} & $\begin{array}{l}\text { Barrier } \\
\text { WP Side }\end{array}$ & $30 \mathrm{~Pa}$ & $\begin{array}{c}\text { PCB } \\
113 A 26\end{array}$ & 10001 & 500psig & 200psig & 250psig & $5 \mathrm{~V}$ & 1V & $4 \mathrm{~V}$ & $\begin{array}{c}4 / 3 \\
20 \mathrm{kS} / \mathrm{s}, 10 \mathrm{kHz}\end{array}$ & \\
\hline & $\begin{array}{l}\text { Barrier } \\
\text { WP Side }\end{array}$ & $30 \mathrm{~Pb}$ & $\begin{array}{c}\text { PCB } \\
113 A 26\end{array}$ & 10002 & 500psig & 200psig & 250psig & $5 \mathrm{~V}$ & $1 \mathrm{~V}$ & $4 V$ & \begin{tabular}{|c|}
$5 / 4$ \\
$20 \mathrm{kS} / \mathrm{s}, 10 \mathrm{kHz}$
\end{tabular} & 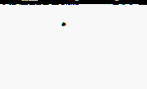 \\
\hline \multirow[t]{2}{*}{4} & $\begin{array}{c}\text { Barrier } \\
\text { WP Side }\end{array}$ & $40 \mathrm{~Pa}$ & $\begin{array}{c}\text { PCB } \\
113 A 26\end{array}$ & 10004 & 500psig & 200psig & 250psig & $5 \mathrm{~V}$ & $1 \mathrm{~V}$ & $4 V$ & $\begin{array}{c}6 / 5 \\
20 \mathrm{kS} / \mathrm{s}, 10 \mathrm{kHz}\end{array}$ & \\
\hline & $\begin{array}{l}\text { Barrier } \\
\text { WP Side }\end{array}$ & $40 \mathrm{~Pb}$ & $\begin{array}{c}\text { PCB } \\
113 A 26\end{array}$ & 10005 & 500psig & 200psig & 250psig & $5 \mathrm{~V}$ & $1 \mathrm{~V}$ & $4 V$ & $\begin{array}{c}7 / 6 \\
20 \mathrm{kS} / \mathrm{s}, 10 \mathrm{kHz}\end{array}$ & \\
\hline \multirow[t]{2}{*}{5} & $\begin{array}{c}\text { Barrier } \\
\text { WP Side }\end{array}$ & $50 \mathrm{~Pa}$ & $\begin{array}{c}\text { PCB } \\
113 A 26\end{array}$ & 10006 & 500psig & 200psig & 250psig & $5 \mathrm{~V}$ & 1V & $4 V$ & $\begin{array}{c}8 / 7 \\
20 \mathrm{kS} / \mathrm{s}, 10 \mathrm{kHz}\end{array}$ & \\
\hline & $\begin{array}{c}\text { Barrier } \\
\text { WP Side }\end{array}$ & $50 \mathrm{~Pb}$ & $\begin{array}{c}\text { PCB } \\
113 A 26\end{array}$ & 10007 & 500psig & 200psig & 250psig & $5 \mathrm{~V}$ & $1 \mathrm{~V}$ & $4 \mathrm{~V}$ & \begin{tabular}{|c|}
$9 / 8$ \\
$20 \mathrm{kS} / \mathrm{s}, 10 \mathrm{kHz}$
\end{tabular} & \\
\hline \multirow[t]{2}{*}{6} & $\begin{array}{c}\text { Barrier } \\
\text { WP Side }\end{array}$ & $60 \mathrm{~Pa}$ & $\begin{array}{c}\text { PCB } \\
113 A 26\end{array}$ & 10008 & 500psig & 200psig & 250psig & $5 \mathrm{~V}$ & $1 \mathrm{~V}$ & $4 V$ & $\begin{array}{c}10 / 9 \\
20 \mathrm{kS} / \mathrm{s}, 10 \mathrm{kHz}\end{array}$ & \\
\hline & $\begin{array}{l}\text { Barrier } \\
\text { WP Side }\end{array}$ & $6 \mathrm{OPb}$ & $\begin{array}{c}\text { PCB } \\
113 A 26\end{array}$ & 10009 & 500psig & 200psig & 250psig & $5 \mathrm{~V}$ & 1V & $4 \mathrm{~V}$ & \begin{tabular}{c|}
$11 / 10$ \\
$20 \mathrm{kS} / \mathrm{s}, 10 \mathrm{kHz}$
\end{tabular} & \\
\hline 7 & $\begin{array}{l}\text { Barrier } \\
\text { WP Side }\end{array}$ & $70 \mathrm{~Pa}$ & $\begin{array}{l}. \text { PCB } \\
113 A 26\end{array}$ & 10010 & 500psig & 200psig & 250psig & $5 \mathrm{~V}$ & $1 \mathrm{~V}$ & $4 V$ & \begin{tabular}{c|}
$12 / 11$ \\
$20^{\prime} \cdot \mathrm{S} / \mathrm{s}, 10 \mathrm{kHz}$
\end{tabular} & \\
\hline
\end{tabular}




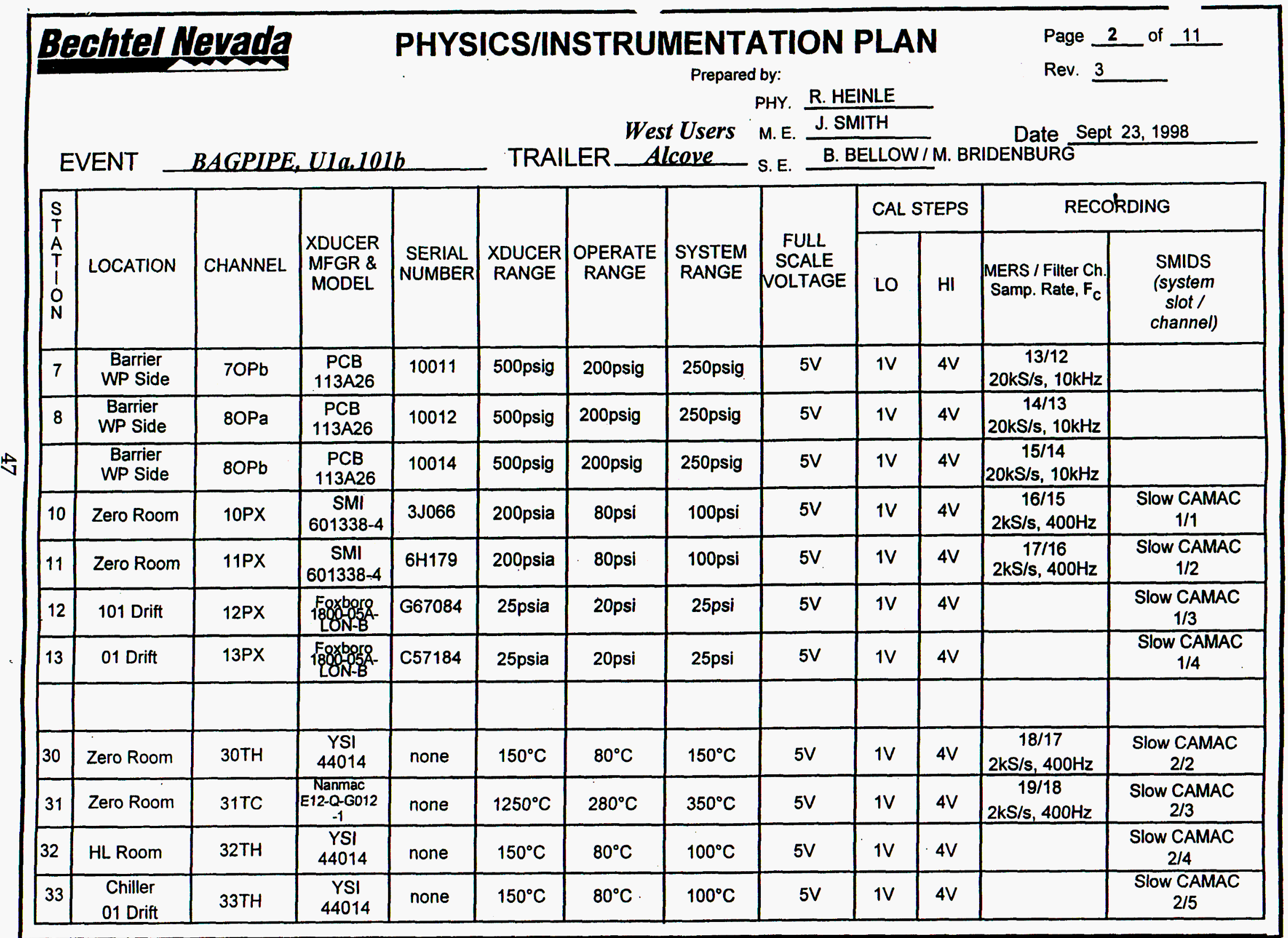




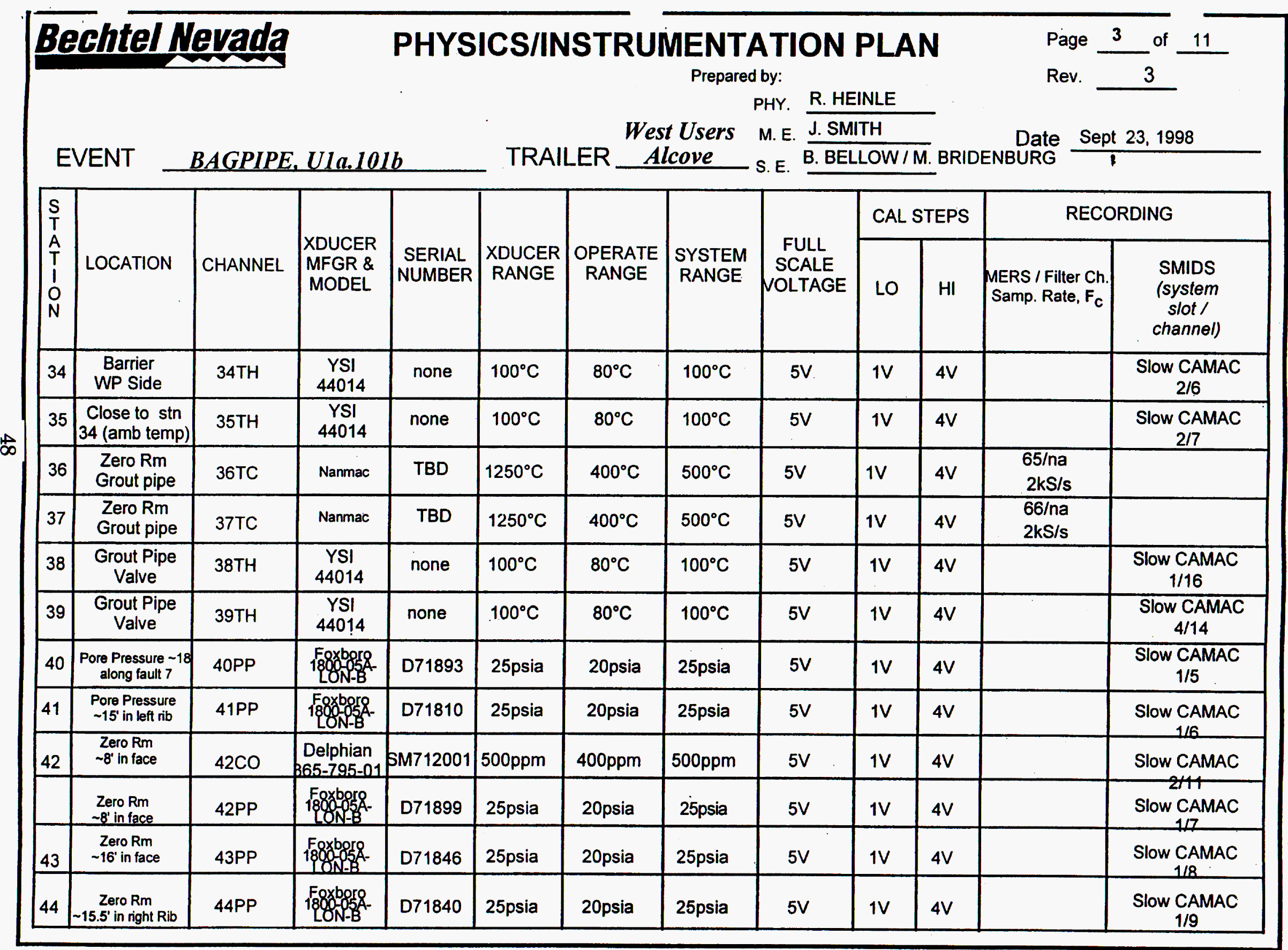




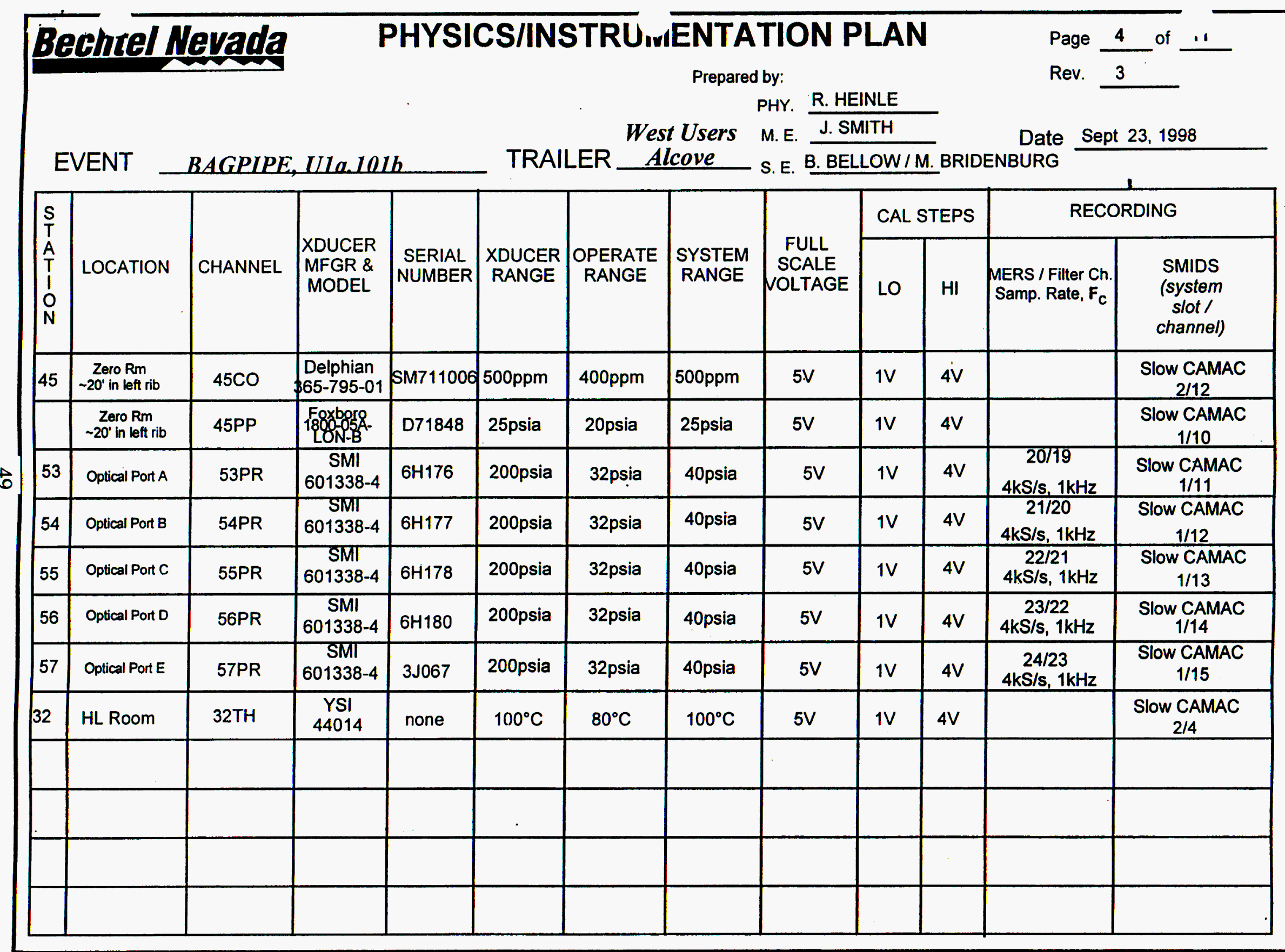




\section{EVENT RAGPIPE, Ula.101b}

PHY. R. HEINLE

West Users

M. E. J. SMITH

Date Sept 23 TRAILER Alcove S.E. B. BELLOW/M. BRIDENBURG

1998

\begin{tabular}{|c|c|c|c|c|c|c|c|c|c|c|c|c|}
\hline \multirow{2}{*}{\begin{tabular}{|l} 
S \\
T \\
A \\
T \\
\\
$O$ \\
N
\end{tabular}} & \multirow[b]{2}{*}{$\begin{array}{l}\text { LOCATION } \\
\text { Pen Bribe }\end{array}$} & \multirow[b]{2}{*}{$\begin{array}{l}\text { CHANNEL } \\
\text { bey }\end{array}$} & \multirow[b]{2}{*}{$\begin{array}{l}\text { XDUCER } \\
\text { MFGR \& } \\
\text { MODEL }\end{array}$} & \multirow[b]{2}{*}{$\begin{array}{c}\text { SERIAL } \\
\text { NUMBER }\end{array}$} & \multirow[b]{2}{*}{\begin{tabular}{|} 
XDUCER \\
RANGE
\end{tabular}} & \multirow[b]{2}{*}{$\begin{array}{l}\text { OPERATE } \\
\text { RANGE }\end{array}$} & \multirow[b]{2}{*}{$\begin{array}{l}\text { SYSTEM } \\
\text { RANGE }\end{array}$} & \multirow[b]{2}{*}{$\begin{array}{c}\text { FULL } \\
\text { SCALE } \\
\text { NOLTAGE }\end{array}$} & \multicolumn{2}{|c|}{ CAL STEPS } & \multicolumn{2}{|c|}{ RECORDING } \\
\hline & & & & & & & & & LO & $\mathrm{HI}$ & $\begin{array}{l}\text { MERS / Filter Ch. } \\
\text { Samp. Rate, } F_{C}\end{array}$ & $\begin{array}{l}\text { SMIDS } \\
\text { (system } \\
\text { slot / } \\
\text { channel) }\end{array}$ \\
\hline \multirow[t]{2}{*}{60} & $\begin{array}{l}\text { Zero } \mathrm{Rm} \\
\text { facing left rib }\end{array}$ & 60IRa & $\begin{array}{c}\text { Mikron } \\
\text { M-50 }\end{array}$ & 1230 & $300^{\circ} \mathrm{C}$ & $240^{\circ} \mathrm{C}$ & $300^{\circ} \mathrm{C}$ & $5 \mathrm{~V}$ & $1 \mathrm{~V}$ & $4 \mathrm{~V}$ & $\begin{array}{c}25 / 24 \\
4 \mathrm{kS} / \mathrm{s}, 1 \mathrm{kHz} \\
\end{array}$ & $\begin{array}{c}\text { MERS Event } 3 \\
\text { Ch } 25-10 S / s\end{array}$ \\
\hline & $\begin{array}{c}\text { Zero Rm } \\
\text { facing exp. } 1 \& 2\end{array}$ & $60 I R b$ & $\begin{array}{c}\text { Mikron } \\
\text { M-50 } \\
\end{array}$ & 1232 & $300^{\circ} \mathrm{C}$ & $240^{\circ} \mathrm{C}$ & $300^{\circ} \mathrm{C}$ & $5 \mathrm{~V}$ & $1 \mathrm{~V}$ & $4 \mathrm{~V}$ & $\begin{array}{c}26 / 25 \\
4 \mathrm{kS} / \mathrm{s}, 1 \mathrm{kHz}\end{array}$ & $\begin{array}{c}\text { MERS Event } 3 \\
\text { Ch } 26-10 \text { S/s }\end{array}$ \\
\hline \multirow[t]{2}{*}{61} & $\begin{array}{c}\text { Zero } \mathrm{Rm} \\
\text { facing left rib } \uparrow\end{array}$ & 61IRa & $\begin{array}{l}\text { Mikron } \\
\text { M-50 }\end{array}$ & 2306 & $300^{\circ} \mathrm{C}$ & $240^{\circ} \mathrm{C}$ & $300^{\circ} \mathrm{C}$ & $5 \mathrm{~V}$ & 1V & $4 \mathrm{~V}$ & $\begin{array}{c}27 / 26 \\
4 \mathrm{kS} / \mathrm{s}, 1 \mathrm{kHz}\end{array}$ & $\begin{array}{l}\text { MERS Event } 3 \\
\text { Ch } 27-10 \text { S/s }\end{array}$ \\
\hline & \begin{tabular}{|c|} 
Zero $R m$ \\
facing exp. $3 \& 4$ \\
\end{tabular} & 61IRB & $\begin{array}{c}\text { Mikron } \\
\text { M-50 }\end{array}$ & 2308 & $300^{\circ} \mathrm{C}$ & $240^{\circ} \mathrm{C}$ & $300^{\circ} \mathrm{C}$ & $5 \mathrm{~V}$ & IV & $4 \mathrm{~V}$ & $\begin{array}{c}28 / 27 \\
4 \mathrm{kS} / \mathrm{s}, 1 \mathrm{kHz} \\
\end{array}$ & $\begin{array}{l}\text { MERS Event } 3 \\
\text { Ch } 28-10 S / s\end{array}$ \\
\hline \multirow[t]{3}{*}{70} & $\begin{array}{c}\text { Zero Rm } \\
\text { left rib }\end{array}$ & $70 \mathrm{CO}$ & \begin{tabular}{|c|} 
Sierra \\
$4101-04$ \\
\end{tabular} & 88-DD-644 & 500PPM & 80PPM & 150PPM & $5 \mathrm{~V}$ & $1 \mathrm{~V}$ & $4 \mathrm{~V}$ & & $\begin{array}{c}\text { Slow CAMAC } \\
2 / 13 \\
\end{array}$ \\
\hline & $\begin{array}{l}\text { Zero } \mathrm{Rm} \\
\text { left rib }\end{array}$ & $70 \mathrm{CO} 2$ & $\begin{array}{c}\text { IST } \\
\text { SM95-IR }\end{array}$ & $\mid 420-2616$ & $10 \%$ Nol & $2 \% \mathrm{Nol}$ & $1.6 \%$ Nol & $5 \mathrm{~V}$ & $1 \mathrm{~V}$ & $4 \mathrm{~V}$ & & $\begin{array}{c}\text { Slow CAMAC } \\
2 / 14\end{array}$ \\
\hline & $\begin{array}{c}\begin{array}{c}\text { Zero } \mathrm{Rm} \\
\text { left rib }\end{array} \\
01 \text { riff }\end{array}$ & 7002 & \begin{tabular}{|c|} 
Sierra \\
$4101-03$ \\
\end{tabular} & p8-C-2695 & $\begin{array}{c}25 \% \text { O2 } \\
\text { by Vol }\end{array}$ & $\begin{array}{c}20 \% \mathrm{O} 2 \\
\text { by Vol }\end{array}$ & $\begin{array}{c}25 \% \mathrm{O} 2 \\
\text { by Vol }\end{array}$ & $5 \mathrm{~V}$ & $1 \mathrm{~V}$ & $4 \mathrm{~V}$ & & $\begin{array}{c}\text { Slow CAMAC } \\
2 / 15 \\
\end{array}$ \\
\hline 71 & $\begin{array}{c}101 \text { Drift } \\
\text { left rib }\end{array}$ & $71 \mathrm{CO}$ & $\begin{array}{c}\text { MSA } \\
494369\end{array}$ & none & 1500PPM & 800PPM & $\underset{\mathrm{M}}{1000 \mathrm{PP}}$ & $5 \mathrm{~V}$ & IV & $4 \mathrm{~V}$ & & $\begin{array}{c}\text { Slow CAMAC } \\
2 / 16 \\
\end{array}$ \\
\hline 80 & $\begin{array}{l}\text { Zero Rm side } \\
\text { of barrier }\end{array}$ & 80AR & $\begin{array}{c}\text { Endevco } \\
2262 A\end{array}$ & CR45 & $300 \mathrm{~g}$ & $240 \mathrm{~g}$ & $300 \mathrm{~g}$ & $5 \mathrm{~V}$ & $1 \mathrm{~V}$ & $4 \mathrm{~V}$ & $\begin{array}{c}29 / 28 \\
20 \mathrm{kS} / \mathrm{s}, 4 \mathrm{kHz} \\
\end{array}$ & \\
\hline \multirow[t]{3}{*}{81} & $\begin{array}{c}101 \text { side of barrier } \\
\text { on redwood }\end{array}$ & 81AV & \begin{tabular}{|c|} 
Endevco \\
$2262 A$ \\
\end{tabular} & AD28 & $80 \mathrm{~g}$ & $64 \mathrm{~g}$ & $80 \mathrm{~g}$ & $5 \mathrm{~V}$ & $1 \mathrm{~V}$ & $4 \mathrm{~V}$ & $\begin{array}{c}30 / 29 \\
20 \mathrm{kS} / \mathrm{s}, 4 \mathrm{kHz} \\
\end{array}$ & \\
\hline & $\begin{array}{c}101 \text { side of barrier } \\
\text { on redwood }\end{array}$ & $81 \mathrm{AT}$ & $\begin{array}{c}\text { Endevco } \\
2262 \mathrm{~A}\end{array}$ & TH78 & $80 \mathrm{~g}$ & $64 \mathrm{~g}$ & $80 \mathrm{~g}$ & $5 \mathrm{~V}$ & $1 \mathrm{~V}$ & $4 \mathrm{~V}$ & $\begin{array}{c}31 / 30 \\
20 \mathrm{kS} / \mathrm{s}, 4 \mathrm{kHz} \\
\end{array}$ & \\
\hline & $\begin{array}{c}101 \text { side of barrier } \\
\text { on redwood }\end{array}$ & $81 \mathrm{AR}$ & $\begin{array}{c}\text { Endevco } \\
2262 A\end{array}$ & L11956 & $80 \mathrm{~g}$ & $64 \mathrm{~g}$ & $80 \mathrm{~g}$ & $5 \mathrm{~V}$ & $1 \mathrm{~V}$ & $4 \mathrm{~V}$ & $\begin{array}{c}32 / 31 \\
20 \mathrm{kS} / \mathrm{s}, 4 \mathrm{kHz} \\
\end{array}$ & \\
\hline
\end{tabular}




\begin{tabular}{|c|c|c|c|c|c|c|c|c|c|c|c|c|}
\hline \multirow{4}{*}{\multicolumn{2}{|c|}{ EVENT }} & \multirow{4}{*}{\multicolumn{3}{|c|}{ BAGPIPE, Ula, IOLh }} & \multicolumn{6}{|c|}{ Prepared by: } & \multicolumn{2}{|c|}{ rev. s } \\
\hline & & & & & \multirow{3}{*}{\multicolumn{3}{|c|}{ TRAILER $\begin{array}{c}\text { West Users } \\
\text { Alcove }\end{array}$}} & \multirow{2}{*}{\multicolumn{2}{|c|}{$\begin{array}{l}\text { PHY: } \frac{\text { R. HEINLE }}{\text { J. SMITH }} \\
\text { M.E. }\end{array}$}} & & & \\
\hline & & & & & & & & \multirow{2}{*}{\multicolumn{4}{|c|}{$\begin{array}{l}\text { M.E. } \frac{\text { Date Sept }}{\text { B. BELLOW/M. BRIDENBURG }} \\
\text { S. E. }\end{array}$}} & 1998 \\
\hline & & & & & & & & & & & & \\
\hline \multirow{2}{*}{$\begin{array}{l}\text { S } \\
T \\
A \\
T \\
1 \\
O \\
\text { N }\end{array}$} & \multirow[b]{2}{*}{ LOCATION } & \multirow[b]{2}{*}{ CHANNEL } & \multirow[b]{2}{*}{$\begin{array}{l}\text { XDUCER } \\
\text { MFGR \& } \\
\text { MODEL }\end{array}$} & \multirow[b]{2}{*}{$\begin{array}{l}\text { SERIAL } \\
\text { NUMBER }\end{array}$} & \multirow[b]{2}{*}{$\begin{array}{l}\text { XDUCER } \\
\text { RANGE }\end{array}$} & \multirow[b]{2}{*}{$\begin{array}{l}\text { OPERATE } \\
\text { RANGE }\end{array}$} & \multirow[b]{2}{*}{$\begin{array}{l}\text { SYSTEM } \\
\text { RANGE }\end{array}$} & \multirow[b]{2}{*}{$\begin{array}{c}\text { FULL } \\
\text { SCALE } \\
\text { NOLTAGE }\end{array}$} & \multicolumn{2}{|c|}{ CAL STEPS } & \multicolumn{2}{|c|}{ RECORDING } \\
\hline & & & & & & & & & LO & $\mathrm{HI}$ & $\begin{array}{l}\text { MERS / Filter Ch. } \\
\text { Samp. Rate, } F_{\mathrm{c}}\end{array}$ & $\begin{array}{l}\text { SMIDS } \\
\text { (system } \\
\text { slot / } \\
\text { channel) }\end{array}$ \\
\hline 82 & $\begin{array}{c}101 \text { side of barrier } \\
\text { on redwood }\end{array}$ & 82AR & $\begin{array}{c}\text { Endevco } \\
2262 \mathrm{~A}\end{array}$ & CY95 & $300 \mathrm{~g}$ & $240 \mathrm{~g}$ & $300 \mathrm{~g}$ & $5 \mathrm{~V}$ & $1 \mathrm{~V}$ & $4 \mathrm{~V}$ & \begin{tabular}{c|}
$33 / 32$ \\
$20 \mathrm{kS} / \mathrm{s}, 4 \mathrm{kHz}$
\end{tabular} & \\
\hline 90 & $\begin{array}{l}\text { Embedment } \\
\text { right rib }\end{array}$ & 90SG & $\begin{array}{c}\mathrm{MM} \\
\text { EGP-5-350 }\end{array}$ & none & $\begin{array}{l}1000 \\
\mu \text { strain }\end{array}$ & $480 \mu$ strain & $600 \mu$ strain & $5 \mathrm{~V}$ & IV & $4 \mathrm{~V}$ & \begin{tabular}{|c|}
$34 / 33$ \\
$20 \mathrm{kS} / \mathrm{s}, 4 \mathrm{kHz}$
\end{tabular} & \\
\hline 91 & Back right & 91SG & $\begin{array}{c}\text { MM } \\
\text { EGP-5-350 }\end{array}$ & none & $\begin{array}{c}1000 \\
\mu \text { strain }\end{array}$ & $480 \mu$ strain & $600 \mu$ strain & $5 \mathrm{~V}$ & 1V & $4 \mathrm{~V}$ & $\begin{array}{c}35 / 34 \\
20 \mathrm{kS} / \mathrm{s}, 4 \mathrm{kHz}\end{array}$ & \\
\hline 92 & Back center & 92SG & $\begin{array}{c}\text { MM } \\
\text { EGP-5-350 } \\
\end{array}$ & none & $\begin{array}{c}1000 \\
\mu \text { strain }\end{array}$ & $480 \mu$ strain & $600 \mu$ strain & $5 \mathrm{~V}$ & $1 \mathrm{~V}$ & $4 \mathrm{~V}$ & $\begin{array}{c}36 / 35 \\
20 \mathrm{kS} / \mathrm{s}, 4 \mathrm{kHz} \\
\end{array}$ & \\
\hline 93 & Back left & 93SG & $\begin{array}{c}\text { MM } \\
\text { EGP-5-350 }\end{array}$ & none & $\begin{array}{c}1000 \\
\mu \text { strain }\end{array}$ & $480 \mu$ strain & $600 \mu$ strain & $5 \mathrm{~V}$ & $1 \mathrm{~V}$ & $4 \mathrm{~V}$ & \begin{tabular}{c|}
$37 / 36$ \\
$20 \mathrm{kS} / \mathrm{s}, 4 \mathrm{kHz}$ \\
\end{tabular} & \\
\hline 94 & Left rib & 94SG & $\begin{array}{c}\text { MM } \\
\text { EGP-5-350 }\end{array}$ & none & $\begin{array}{c}1000 \\
\text { Hstrain }\end{array}$ & $480 \mu$ strain & $600 \mu$ strain & $5 \mathrm{~V}$ & $1 \mathrm{~V}$ & $4 \mathrm{~V}$ & $\begin{array}{c}38 / 37 \\
20 \mathrm{kS} / \mathrm{s}, 4 \mathrm{kHz}\end{array}$ & \\
\hline \multirow[t]{3}{*}{95} & $\begin{array}{l}\text { Keyway } \\
\text { toward face }\end{array}$ & 95SGX & $\begin{array}{c}M M \\
\text { EGP-5-350 }\end{array}$ & none & $\begin{array}{c}1000 \\
\mu \text { strain }\end{array}$ & $480 \mu$ strain & $600 \mu$ strain & $5 \mathrm{~V}$ & $1 \mathrm{~V}$ & $4 \mathrm{~V}$ & $\begin{array}{c}39 / 38 \\
20 \mathrm{kS} / \mathrm{s}, 4 \mathrm{kHz}\end{array}$ & \\
\hline & $\begin{array}{c}\text { Keyway } \\
\text { toward rt rib }\end{array}$ & 95SGy & $\begin{array}{c}\text { MM } \\
\text { EGP-5-350 }\end{array}$ & none & $\begin{array}{c}1000 \\
\text { Hstrain }\end{array}$ & $480 \mu$ strain & $600 \mu$ strain & $5 \mathrm{~V}$ & $1 \mathrm{~V}$ & $4 \mathrm{~V}$ & $\begin{array}{c}40 / 39 \\
20 \mathrm{kS} / \mathrm{s}, 4 \mathrm{kHz}\end{array}$ & \\
\hline & $\begin{array}{c}\text { Keyway } \\
\text { toward invert }\end{array}$ & $95 S G z$ & \begin{tabular}{c|}
$M M$ \\
EGP-5-350 \\
\end{tabular} & none & $\begin{array}{c}1000 \\
\mu s t r a i n\end{array}$ & $480 \mu$ strain & $600 \mu$ strain & $5 \mathrm{~V}$ & $1 \mathrm{~V}$ & $4 \mathrm{~V}$ & $\begin{array}{c}41 / 40 \\
20 \mathrm{kS} / \mathrm{s}, 4 \mathrm{kHz} \\
\end{array}$ & \\
\hline 96 & $\begin{array}{l}\text { Left web at } \\
\text { back }\end{array}$ & 96SG & $\begin{array}{c}M M \\
\text { EGP-5-350 }\end{array}$ & none & $\begin{array}{c}1000 \\
\mu s t r a i n\end{array}$ & $480 \mu$ strain & $600 \mu$ strain & $5 \mathrm{~V}$ & $1 \mathrm{~V}$ & $4 \mathrm{~V}$ & $\begin{array}{c}42 / 41 \\
20 \mathrm{kS} / \mathrm{s}, 4 \mathrm{kHz}\end{array}$ & \\
\hline 97 & $\begin{array}{c}\text { Left mid web } \\
\text { at back }\end{array}$ & $97 S G$ & $\begin{array}{c}M M \\
\text { EGP-5-350 }\end{array}$ & none & $\begin{array}{c}1000 \\
\mu \text { strain }\end{array}$ & $480 \mu$ strain & $600 \mu$ strain & $5 \mathrm{~V}$ & $1 \mathrm{~V}$ & $4 \mathrm{~V}$ & $\begin{array}{c}43 / 42 \\
20 \mathrm{kS} / \mathrm{s}, 4 \mathrm{kHz}\end{array}$ & \\
\hline 98 & $\begin{array}{l}\text { Center web } \\
\text { at back }\end{array}$ & 98SG & $\begin{array}{c}M M \\
\text { EGP-5-350 }\end{array}$ & none & $\begin{array}{c}1000 \\
\mu \text { strain }\end{array}$ & $480 \mu$ strain & poo $\mu$ strain & $5 \mathrm{~V}$ & $1 \mathrm{~V}$ & $4 \mathrm{~V}$ & $\begin{array}{c}44 / 43 \\
20 \mathrm{kS} / \mathrm{s}, 4 \mathrm{kHz}\end{array}$ & \\
\hline
\end{tabular}




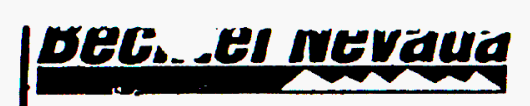

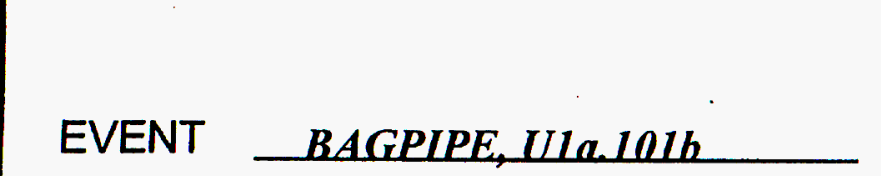

rMIDIUSIIVAIr

IVIEIVIMIIUIV ILRIX

Prepared by:

PHY, R. HEINLE

West Users M. E. J.SMITH TRAILER Alcove
Rev. 3

Date Sept 23, 1998 S.E. B. BELLOW/M. BRIDENBURG

\begin{tabular}{|c|c|c|c|c|c|c|c|c|c|c|c|c|}
\hline \multirow{2}{*}{$\begin{array}{l}S \\
T \\
A \\
T \\
I \\
O \\
N\end{array}$} & \multirow[b]{2}{*}{ LOCATION } & \multirow[b]{2}{*}{ CHANNEL } & \multirow[b]{2}{*}{$\begin{array}{l}\text { XDUCER } \\
\text { MFGR \& } \\
\text { MODEL }\end{array}$} & \multirow[b]{2}{*}{$\begin{array}{l}\text { SERIAL } \\
\text { NUMBER }\end{array}$} & \multirow[b]{2}{*}{$\begin{array}{l}\text { XDUCER } \\
\text { RANGE }\end{array}$} & \multirow[b]{2}{*}{$\begin{array}{l}\text { PPERATE } \\
\text { RANGE }\end{array}$} & \multirow[b]{2}{*}{$\begin{array}{l}\text { SYSTEM } \\
\text { RANGE }\end{array}$} & \multirow[b]{2}{*}{$\begin{array}{c}\text { FULL } \\
\text { SCALE } \\
\text { NOLTAGE }\end{array}$} & \multicolumn{2}{|c|}{ CAL STEPS } & \multicolumn{2}{|c|}{ RECORDING } \\
\hline & & & & & & & & & LO & $\mathrm{HI}$ & $\begin{array}{l}\text { MERS / Filter Ch. } \\
\text { Samp. Rate, } F_{\mathbf{c}}\end{array}$ & $\begin{array}{l}\text { SMIDS } \\
\text { (system } \\
\text { slot/ } \\
\text { channel) }\end{array}$ \\
\hline \multirow[t]{2}{*}{100} & $\begin{array}{l}\text { Rosette by crawl } \\
\text { tube on web }\end{array}$ & 100 SG-1 & $\begin{array}{c}\mathrm{MM} \\
\text { Rosette } \\
\end{array}$ & none & 1000 ustrain & $800 \mu$ strain & [1000 ustrain ] & $5 \mathrm{~V}$ & IV & $4 \mathrm{~V}$ & $\begin{array}{c}45 / 44 \\
20 \mathrm{kS} / \mathrm{s}, 4 \mathrm{kHz} \\
\end{array}$ & \\
\hline & & 100SG-3 & $\begin{array}{c}\mathrm{MM} \\
\text { Rosette }\end{array}$ & none & $1000 \mu$ strain & $800 \mu$ strain & $1000 \mu$ strain & $5 \mathrm{~V}$ & IV & $4 \mathrm{~V}$ & $\begin{array}{c}47 / 46 \\
20 \mathrm{kS} / \mathrm{s}, 4 \mathrm{kHz} \\
\end{array}$ & \\
\hline \multirow[t]{2}{*}{101} & $\begin{array}{l}\begin{array}{l}\text { Rosette left of } \\
\text { center I beam }\end{array} \\
\end{array}$ & 101SG-1 & $\begin{array}{c}\mathrm{MM} \\
\text { Rosette } \\
\end{array}$ & none & 1000 ustrain & $800 \mu$ strain & $1000 \mu$ strain & $5 \mathrm{~V}$ & IV & $4 \mathrm{~V}$ & $\begin{array}{c}48 / 47 \\
20 \mathrm{kS} / \mathrm{s}, 4 \mathrm{kHz} \\
\end{array}$ & \\
\hline & & 101SG-2 & $\begin{array}{c}\mathrm{MM} \\
\text { Rosette } \\
\end{array}$ & none & $1000 \mu$ strain & $800 \mu$ strain & $1000 \mu$ strain & $5 \mathrm{~V}$ & IV & $4 \mathrm{~V}$ & \begin{tabular}{|c|}
$49 / 48$ \\
$20 \mathrm{kS} / \mathrm{s}, 4 \mathrm{kHz}$ \\
\end{tabular} & \\
\hline \multirow{5}{*}{102} & & 102SG-2 & $\begin{array}{c}\text { MM } \\
\text { Rosette } \\
\end{array}$ & none & $1000 \mu$ strain & $800 \mu$ strain & $1000 \mu$ strain & $5 \mathrm{~V}$ & IV & $4 \mathrm{~V}$ & $\begin{array}{c}52 / 51 \\
20 \mathrm{kS} / \mathrm{s}, 4 \mathrm{kHz} \\
\end{array}$ & \\
\hline & & 102SG-3 & $\begin{array}{c}\text { MM } \\
\text { Rosette }\end{array}$ & none & $1000 \mu$ strain & $800 \mu$ strain & $1000 \mu$ strain & $5 \mathrm{~V}$ & IV & $4 V$ & $\begin{array}{c}53 / 52 \\
20 \mathrm{kS} / \mathrm{s}, 4 \mathrm{kHz} \\
\end{array}$ & \\
\hline & & & & & & & & & & & & \\
\hline & & & & & & & & & & & & \\
\hline & & & & & & & & & & & & \\
\hline
\end{tabular}


PHY. R. HEINLE

West Users M. E. J.SMITH

Date Sept 23, 1998

EVENT BAGPIPE, Ula.lelb TRAILER Alcove S. E. B. BELLOW/M. BRIDENBURG

\begin{tabular}{|c|c|c|c|c|c|c|c|c|c|c|c|c|}
\hline \multirow{2}{*}{$\begin{array}{l}S \\
T \\
A \\
T \\
1 \\
O \\
N\end{array}$} & \multirow[b]{2}{*}{ LOCATION } & \multirow[b]{2}{*}{ CHANNEL } & \multirow[b]{2}{*}{$\begin{array}{l}\text { XDUCER } \\
\text { MFGR \& } \\
\text { MODEL }\end{array}$} & \multirow[b]{2}{*}{$\begin{array}{c}\text { SERIAL } \\
\text { NUMBER }\end{array}$} & \multirow[b]{2}{*}{$\begin{array}{l}\text { XDUCER } \\
\text { RANGE }\end{array}$} & \multirow[b]{2}{*}{$\begin{array}{l}\text { OPERATE } \\
\text { RANGE }\end{array}$} & \multirow[b]{2}{*}{$\begin{array}{l}\text { SYSTEM } \\
\text { RANGE }\end{array}$} & \multirow[b]{2}{*}{$\begin{array}{c}\text { FULL } \\
\text { SCALE } \\
\text { NOLTAGE }\end{array}$} & \multicolumn{2}{|c|}{ CAL STEPS } & \multicolumn{2}{|c|}{ RECORDING } \\
\hline & & & & & & & & & LO & $\mathrm{HI}$ & $\begin{array}{l}\text { MERS / Filter Ch. } \\
\text { Samp. Rate, } F_{C}\end{array}$ & $\begin{array}{c}\text { SMIDS } \\
\text { (system } \\
\text { slot / } \\
\text { channel) }\end{array}$ \\
\hline 103 & $\begin{array}{l}\text { Barrier Upper } \\
\text { eft Portal Side }\end{array}$ & 103SG & $\begin{array}{c}M M \\
\text { EGP-5-350 }\end{array}$ & none & $1500 \mu s t r a i$ & $11200 \mu$ strain & $1500 \mu$ strain & $5 \mathrm{~V}$ & $1 \mathrm{~V}$ & $4 V$ & $\begin{array}{c}54 / 53 \\
20 \mathrm{kS} / \mathrm{s}, 4 \mathrm{kHz}\end{array}$ & \\
\hline 104 & $\begin{array}{l}\text { Barrier Top Ctr } \\
\text { Left Portal Side }\end{array}$ & 104SG & $\begin{array}{c}\text { MM } \\
\text { EGP-5-350 }\end{array}$ & none & $1500 \mu$ strain & $1200 \mu$ strain & $1500 \mu$ strain & $5 V$ & $1 \mathrm{~V}$ & $4 V$ & $\begin{array}{c}55 / 54 \\
20 \mathrm{kS} / \mathrm{s}, 4 \mathrm{kHz} \\
\end{array}$ & \\
\hline 105 & \begin{tabular}{|c|} 
Barrier Top Ctr \\
Portal Side
\end{tabular} & 105SG & $\begin{array}{c}\mathrm{MM} \\
\text { EGP-5-350 }\end{array}$ & none & $1500 \mu s t r a i r$ & $1200 \mu$ strain & $1500 \mu$ strain & $5 \mathrm{~V}$ & $1 \mathrm{~V}$ & $4 \mathrm{~V}$ & $\begin{array}{c}56 / 55 \\
20 \mathrm{kS} / \mathrm{s}, 4 \mathrm{kHz}\end{array}$ & \\
\hline 106 & $\begin{array}{l}\text { Barrier Top Crt } \\
\text { Rt Portal Side }\end{array}$ & 106SG & $\begin{array}{c}\text { MM } \\
\text { EGP-5-350 }\end{array}$ & none & 1500 ustrair & $1200 \mu$ strain & $1500 \mu$ strain & $5 \mathrm{~V}$ & $1 \mathrm{~V}$ & $4 \mathrm{~V}$ & $\begin{array}{c}57 / 56 \\
20 \mathrm{kS} / \mathrm{s}, 4 \mathrm{kHz} \\
\end{array}$ & \\
\hline 107 & $\begin{array}{l}\text { Barrier Upper } \\
\text { Rt Portal Side } \\
\end{array}$ & 107SG & $\begin{array}{c}\mathrm{MM} \\
\text { EGP-5-350 } \\
\end{array}$ & none & $1500 \mu$ strain & $1200 \mu$ strain & 1500 ustrain & $5 \mathrm{~V}$ & $1 \mathrm{~V}$ & $4 V$ & $\begin{array}{c}58 / 57 \\
20 \mathrm{kS} / \mathrm{s}, 4 \mathrm{kHz} \\
\end{array}$ & \\
\hline 108 & $\begin{array}{l}\text { Barrier Lower } \\
\text { Rt Portal Side } \\
\end{array}$ & 108SG & $\begin{array}{c}M M \\
\text { EGP-5-350 }\end{array}$ & none & $1500 \mu$ strain & $1200 \mu$ strain & $1500 \mu$ strain & $5 \mathrm{~V}$ & 1V & $4 \mathrm{~V}$ & $\begin{array}{c}59 / 58 \\
20 \mathrm{kS} / \mathrm{s}, 4 \mathrm{kHz}\end{array}$ & \\
\hline 109 & $\begin{array}{l}\text { Barrier Lower } \\
\text { Rtt Portal Side }\end{array}$ & $109 \mathrm{SG}$ & $\begin{array}{c}M M \\
\text { EGP-5-350 }\end{array}$ & none & $1500 \mu$ strain & $1200 \mu$ strain & $1500 \mu$ strain & $5 \mathrm{~V}$ & $1 \mathrm{~V}$ & $4 \mathrm{~V}$ & $\begin{array}{c}60 / 59 \\
20 \mathrm{kS} / \mathrm{s}, 4 \mathrm{kHz}\end{array}$ & \\
\hline 110 & $\begin{array}{l}\text { Barrier Low Mid } \\
\text { Rt Portal Side } \\
\end{array}$ & $110 S G$ & $\begin{array}{c}\mathrm{MM} \\
\text { EGP-5-350 } \\
\end{array}$ & none & $1500 \mu$ strair & 1200 ustrain & $1500 \mu$ strain & $5 \mathrm{~V}$ & $1 \mathrm{~V}$ & $4 \mathrm{~V}$ & $\begin{array}{c}61 / 60 \\
20 \mathrm{kS} / \mathrm{s}, 4 \mathrm{kHz}\end{array}$ & \\
\hline 111 & \begin{tabular}{|c|} 
Barrier Low Ctr \\
Portal Side
\end{tabular} & 111SG & $\begin{array}{c}\text { MM } \\
\text { EGP-5-350 }\end{array}$ & none & $1500 \mu$ strain & $1200 \mu$ strain & $1500 \mu$ strain & $5 \mathrm{~V}$ & IV & $4 \mathrm{~V}$ & $\begin{array}{c}62 / 61 \\
20 \mathrm{kS} / \mathrm{s}, 4 \mathrm{kHz}\end{array}$ & \\
\hline 112 & \begin{tabular}{|l|} 
Barrier Under \\
Acess Portal
\end{tabular} & $112 S G$ & \begin{tabular}{|c|}
$M M$ \\
EGP-5-350
\end{tabular} & none & $1500 \mu$ strain & $1200 \mu$ strain & $1500 \mu$ strain & $5 \mathrm{~V}$ & $1 \mathrm{~V}$ & $4 \mathrm{~V}$ & $\begin{array}{c}63 / 62 \\
20 \mathrm{kS} / \mathrm{s}, 4 \mathrm{kHz}\end{array}$ & \\
\hline 113 & \begin{tabular}{|c|} 
Barrier Center \\
Portal Side \\
\end{tabular} & 113SG & $\begin{array}{c}\mathrm{MM} \\
\text { EGP-5-350 }\end{array}$ & none & $1500 \mu$ strain & $1200 \mu$ strain & $1500 \mu$ strain & $5 \mathrm{~V}$ & $1 \mathrm{~V}$ & $4 V$ & $\begin{array}{c}64 / 63 \\
20 \mathrm{kS} / \mathrm{s}, 4 \mathrm{kHz} \\
\end{array}$ & \\
\hline 114 & \begin{tabular}{|c|}
$\begin{array}{c}\text { Barrier Above } \\
\text { Portal }\end{array}$ \\
\end{tabular} & $\begin{array}{c}114 S G \\
\text { noise }\end{array}$ & $\begin{array}{c}M \\
\text { EGP-5-350 }\end{array}$ & none & $1500 \mu$ strain & $1200 \mu$ strain & $1500 \mu$ strain & $5 V^{*}$ & $1 V^{*}$ & $4 V^{*}$ & $\begin{array}{c}67 / \mathrm{na} \\
20 \mathrm{kS} / \mathrm{s}, 4 \mathrm{kHz}\end{array}$ & \\
\hline
\end{tabular}




\section{Becntel Nevada}

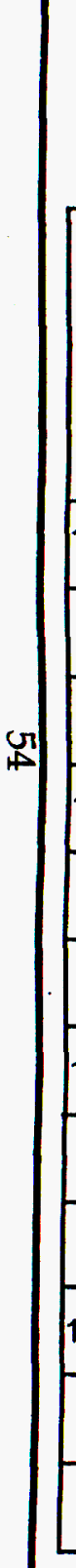

\section{PHYSICS/INSTKUMENTATION PLAN}

Prepared by:

PHY. R. HEINLE

West Users M. E. J. SMITH

TRAILER Alcove
Page 9,11

Rev. 3

EVENT BAGPIPE, ULa.JULh S.E B. BELLOW/M. BRIDENBURG

\begin{tabular}{|c|c|c|c|c|c|c|c|c|c|c|c|}
\hline \multirow[b]{2}{*}{ LOCATION } & \multirow[b]{2}{*}{ CHANNEL } & \multirow[b]{2}{*}{$\begin{array}{l}\text { XDUCER } \\
\text { MFGR \& } \\
\text { MODEL }\end{array}$} & \multirow[b]{2}{*}{$\begin{array}{c}\text { SERIAL } \\
\text { NUMBER }\end{array}$} & \multirow[b]{2}{*}{$\begin{array}{l}\text { XDUCER } \\
\text { RANGE }\end{array}$} & \multirow[b]{2}{*}{$\begin{array}{l}\text { OPERATE } \\
\text { RANGE }\end{array}$} & \multirow[b]{2}{*}{$\begin{array}{l}\text { SYSTEM } \\
\text { RANGE }\end{array}$} & \multirow[b]{2}{*}{$\begin{array}{c}\text { FULL } \\
\text { SCALE } \\
\text { VOLTAGE }\end{array}$} & \multicolumn{2}{|c|}{ CAL STEPS } & \multicolumn{2}{|c|}{ RECORDING } \\
\hline & & & & & & & & LO & $\mathrm{HI}$ & $\begin{array}{l}\text { MERS / Filter Ch. } \\
\text { Samp. Rate, } F_{c}\end{array}$ & $\begin{array}{l}\text { SMIDS } \\
\text { (system } \\
\text { slot / } \\
\text { channel) }\end{array}$ \\
\hline CDU & $120 E-A$ & $108-150$ & none & $150 v a c$ & 120vac & $150 \mathrm{vac}$ & $5 \mathrm{~V}$ & & & & Slow CCAMAC $_{3 / 1}$ \\
\hline CDU & 120E-B & $108-150$ & none & 150vac & 120vac & $150 \mathrm{vac}$ & $5 \mathrm{~V}$ & & & & $\begin{array}{c}\text { Slow CAMAC } \\
3 / 2\end{array}$ \\
\hline CDU & $120 E-C$ & $108-150$ & none & $150 v a c$ & 120vac & $150 v a c$ & $5 \mathrm{~V}$ & & & & $\begin{array}{c}\text { Slow CAMAC } \\
3 / 3\end{array}$ \\
\hline HLR & 121E-A & $108-150$ & none & 150vac & 120vac & $150 \mathrm{vac}$ & $5 \mathrm{~V}$ & & & & $\begin{array}{c}\text { Slow CAMAC } \\
3 / 4\end{array}$ \\
\hline HLR & $121 E-B$ & $108-150$ & none & $150 \mathrm{vac}$ & 120vac & $150 \mathrm{vac}$ & $5 \mathrm{~V}$ & & & & Slow CAMAC $_{3 / 5}$ \\
\hline HLR & $121 \mathrm{E}-\mathrm{C}$ & $108-150$ & none & $150 \mathrm{vac}$ & $120 \mathrm{vac}$ & $150 \mathrm{vac}$ & $5 \mathrm{~V}$ & & & & $\begin{array}{c}\text { Slow CAMAC } \\
3 / 6\end{array}$ \\
\hline HLR Rack & $122 E-A$ & $108-150$ & none & $150 \mathrm{vac}$ & 120vac & $150 \mathrm{vac}$ & $5 \mathrm{~V}$ & & & & Slow CAMAC \\
\hline HLR Rack & $122 \mathrm{E}-\mathrm{B}$ & $108-150$ & none & 150vac & $120 v a c$ & $150 v a c$ & $5 \mathrm{~V}$ & & & & $\begin{array}{c}\text { Slow CAMAC } \\
3 / 8\end{array}$ \\
\hline HLR Rack & $122 \mathrm{E}-\mathrm{C}$ & $108-150$ & none & $150 v a c$ & $120 v a c$ & $150 \mathrm{vac}$ & $5 \mathrm{~V}$ & & & & $\begin{array}{c}\text { Slow ÇAMAC } \\
3 / 9\end{array}$ \\
\hline FPR & $123 E-A$ & $108-150$ & none & $150 \mathrm{vac}$ & $120 v a c$ & $150 \mathrm{vac}$ & $5 \mathrm{~V}$ & & & & $\begin{array}{c}\text { Slow CAMAC } \\
3 / 10\end{array}$ \\
\hline FPR & 123E-B & $108-150$ & none & $150 \mathrm{vac}$ & $120 \mathrm{vac}$ & $150 \mathrm{vac}$ & $5 \mathrm{~V}$ & & & & $\begin{array}{c}\text { Slow CAMAC } \\
3 / 11\end{array}$ \\
\hline FPR & $123 \mathrm{E}-\mathrm{C}$ & 108-150 & none & $150 \mathrm{vac}$ & $120 v a c$ & 150vac & $5 \mathrm{~V}$ & & & & $\begin{array}{c}\text { Slow CAMAC } \\
3 / 12\end{array}$ \\
\hline
\end{tabular}




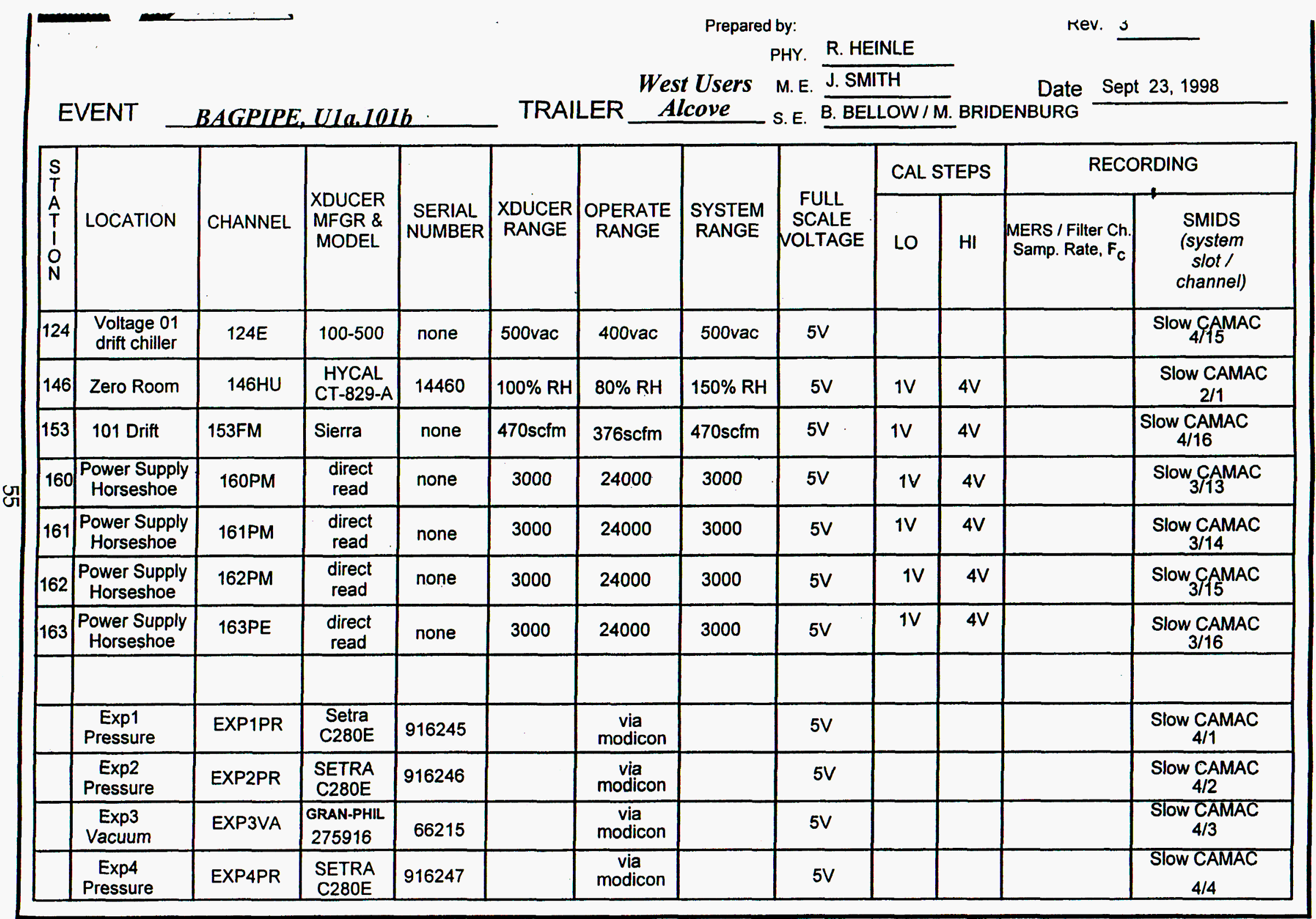


Begucel nevaga

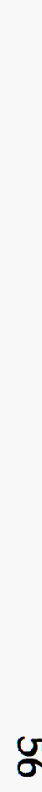

ส

EVENT BAGPIPE, U1a.101b
PHYSICS/INSTR_MENTATION PLAN

Prepared by:

Cam 2 In

Pressure

PHY. R. HEINLE
West Users M. E. J. SMITH

TRAILER Alcove

S.E. B. BELLOW/M. BRIDENBURG rage

Rev. 3

\begin{tabular}{|c|c|c|c|c|c|c|c|c|c|c|c|c|}
\hline \multirow{2}{*}{$\begin{array}{l}S \\
T \\
A \\
T \\
1 \\
O \\
N\end{array}$} & \multirow[b]{2}{*}{ LOCATION } & \multirow[b]{2}{*}{ CHANNEL } & \multirow[b]{2}{*}{$\begin{array}{l}\text { XDUCER } \\
\text { MFGR \& } \\
\text { MODEL }\end{array}$} & \multirow[b]{2}{*}{$\begin{array}{c}\text { SERIAL } \\
\text { NUMBER }\end{array}$} & \multirow[b]{2}{*}{$\begin{array}{l}\text { XDUCER } \\
\text { RANGE }\end{array}$} & \multirow[b]{2}{*}{$\begin{array}{l}\text { OPERATE } \\
\text { RANGE }\end{array}$} & \multirow[b]{2}{*}{$\begin{array}{l}\text { SYSTEM } \\
\text { RANGE }\end{array}$} & \multirow[b]{2}{*}{$\begin{array}{c}\text { FULL } \\
\text { SCALE } \\
\text { VOLTAGE }\end{array}$} & \multicolumn{2}{|c|}{ CAL STEPS } & \multicolumn{2}{|c|}{ RECORDING } \\
\hline & & & & & & & & & LO & $\mathrm{HI}$ & $\begin{array}{l}\text { MERS / Filter Ch. } \\
\text { Samp. Rate, } \text { F }_{\mathrm{C}}\end{array}$ & $\begin{array}{l}\text { SMIDS } \\
\text { (system } \\
\text { slot / } \\
\text { channel) }\end{array}$ \\
\hline & $\begin{array}{c}\text { Drive Supply } \\
\text { Pressure }\end{array}$ & DABTPR & \begin{tabular}{|c|} 
SMI \\
SP976A-5000A \\
A-9A
\end{tabular} & 8D055 & & $\begin{array}{c}\text { via } \\
\text { modicon }\end{array}$ & & $5 \mathrm{~V}$ & & & & $\begin{array}{c}\text { Slow CAMAC } \\
4 / 6 \\
\end{array}$ \\
\hline & $\begin{array}{l}\text { Cntrl Supply } \\
\text { Pressure }\end{array}$ & CABTPR & 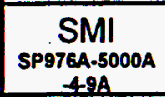 & $8 D 053$ & & $\begin{array}{c}\text { via } \\
\text { modicon }\end{array}$ & & $5 \mathrm{~V}$ & & & & $\begin{array}{c}\text { Slow CAMAC } \\
4 / 7\end{array}$ \\
\hline & $\begin{array}{c}\text { Cam } 1 \text { Drive } \\
\text { Pressure }\end{array}$ & C1DAPR & $\begin{array}{l}\text { SETRA } \\
206\end{array}$ & 913113 & & $\begin{array}{l}\text { via } \\
\text { modicon }\end{array}$ & & $5 V$ & & & & $\begin{array}{c}\text { Slow CAMAC } \\
4 / 9\end{array}$ \\
\hline & $\begin{array}{l}\text { Cam } 1 \text { Cntrl } \\
\text { Pressure }\end{array}$ & C1CAPR & $\begin{array}{l}\text { SETRA } \\
206\end{array}$ & 913650 & & $\begin{array}{c}\text { via } \\
\text { modicon }\end{array}$ & & $5 \mathrm{~V}$ & & & & $\begin{array}{c}\text { Slow CAMAC } \\
4 / 10\end{array}$ \\
\hline & $\begin{array}{c}\text { Cam } 2 \text { Drive } \\
\text { Pressure }\end{array}$ & C2DAPR & $\begin{array}{l}\text { SETRA } \\
206\end{array}$ & 913115 & & $\begin{array}{c}\text { via } \\
\text { modicon }\end{array}$ & & $5 \mathrm{~V}$ & & & & $\begin{array}{c}\text { Slow CAMAC } \\
4 / 12 \\
\end{array}$ \\
\hline & $\begin{array}{c}\text { Cam } 2 \text { Cntrl } \\
\text { Pressure }\end{array}$ & C2CAPR & $\begin{array}{c}\text { SETRA } \\
206 \\
\end{array}$ & 913633 & & $\begin{array}{c}\text { via } \\
\text { modicon }\end{array}$ & & $5 \mathrm{~V}$ & & & & $\begin{array}{c}\text { Slow CAMAC } \\
4 / 13 \\
\end{array}$ \\
\hline & $\checkmark$ & & & & & & & & & & & \\
\hline & & & & & & & & & & & & \\
\hline & & & & & & & & & & & & \\
\hline
\end{tabular}


Appendix B

BAGPIPE Containment Diagnostics Requirements Memo 


\section{Mail Station L-221}

Interdepartmental letterhead Geophysics and Global Security

Ext: 2-5358

January 5, 1998

To: Distribution

From: Ray Heinle

Subject: Bagpipe Containment Diagnostics Requirements, Rev. A

We list below the Containment Diagnostics Requirements for Bagpipe.

\section{Zero Room}

1 Blast Overpressure gage on right rib in line with experiments.

2 quasi-static gas pressure gages in zero room.

Two ambient temperature thermisters

Two infrared thermometers looking at dust cloud (across room to zero-room wall) ${ }^{1}$ at 3 and $8^{\prime}$ elevation

Two infrared thermometers looking at wall. (6" from wall) ${ }^{1}$ at 3 and 8 ' elevation

$1 \mathrm{CO}$ gage at $8^{\prime}$ position into face ${ }^{5}$ at 5 ' elevation

$1 \mathrm{O}_{2}$ detector in zero room (signal to be routed to LANL) ${ }^{3}$

$1 \mathrm{CO}$ detector in zero room (signal to be routed to LANL) ${ }^{3}$

$1 \mathrm{CO}_{2}$ detector in zero room ${ }^{2}$

1 humidity sensor in zero room

2 pore pressure gages at 8 ' and $16^{\prime}$ into face at 5 and 7' elevation

1 pore pressure gage in right rib $16^{\prime}$ deep at 6' elevation

\section{Containment Barrier....Working Point Side}

14 Blast Overpressure gages (see attached sketch).

1 single axis accelerometer (imbedded in fibercrete)

5 imbeddment strain gages in fibercrete at corners (see attached sketch).

\section{Containment Barrier....Portal Side1}

1 three axis accelerometer (damped) on portal side of containment barrier (not expended)

1 single axis accelerometer on portal side of containment barrier (not expended)

10 strain gages on portal side of containment barrier (see attached sketch.)

3 imbeddment strain gages in keyway (see attached sketch).

1 tri-axial strain gage in keyway (see attached sketch)

3 tri-axial "Rosette" gages on containment barrier web.

2 HOLOG Pore pressure gages (fault gages PP 47 and 48)

1 pore pressure gage $20^{\prime}$ into left rib of 101 drift, 30' from zero-room left rib at $6^{\prime}$ elevation

1 CO detector $20^{\prime}$ into left rib of 101 drift, 30' from zero-room left rib at $6^{\prime}$ elevation ${ }^{5}$

1 CO detector mounted on left rib of 101 drift, near $101 \mathrm{~b}$ access drift (not expended) ${ }^{4}$

Five pressure gages on optical ports (one each)

One pressure gage in 101 drift.

One ambient temperature thermistor in $101 \mathrm{drift}$. 
$2 \mathrm{ZnS}$ detectors (fielded by LANL)

2 LRAD detectors (fielded by LANL)

\section{Notes:}

1. Infrared Thermometer Mikron Instruments M50-10-06-U, 6:1 FOV 0-5 v Nonlinear output. Vendor to supply spectral response of unit.

2. International Sensor Technology

3. Sierra Monitor gages 0-500 PPM CO

4. MSA CO gage $0-500$ PPM

5. Delphian gages $0-500$ PPM

\section{Distribution:}

LLNL

C. Anderson, L-142

N. Burkhard, L-221

W. Dekin, L-777

R. Heinle, L-221

J Reed, L-777

J. Wobser, L-170

Bechtel Nevada Corporation

T. Stubbs, AVO A-5

W. Bellow, NLV-065

L. Davies, NL V-065

H. Hall, NTS-330

J. Smith, NTS-330

P. Tanner, NLV-065 


\section{Bagpipe}

(not to scale)

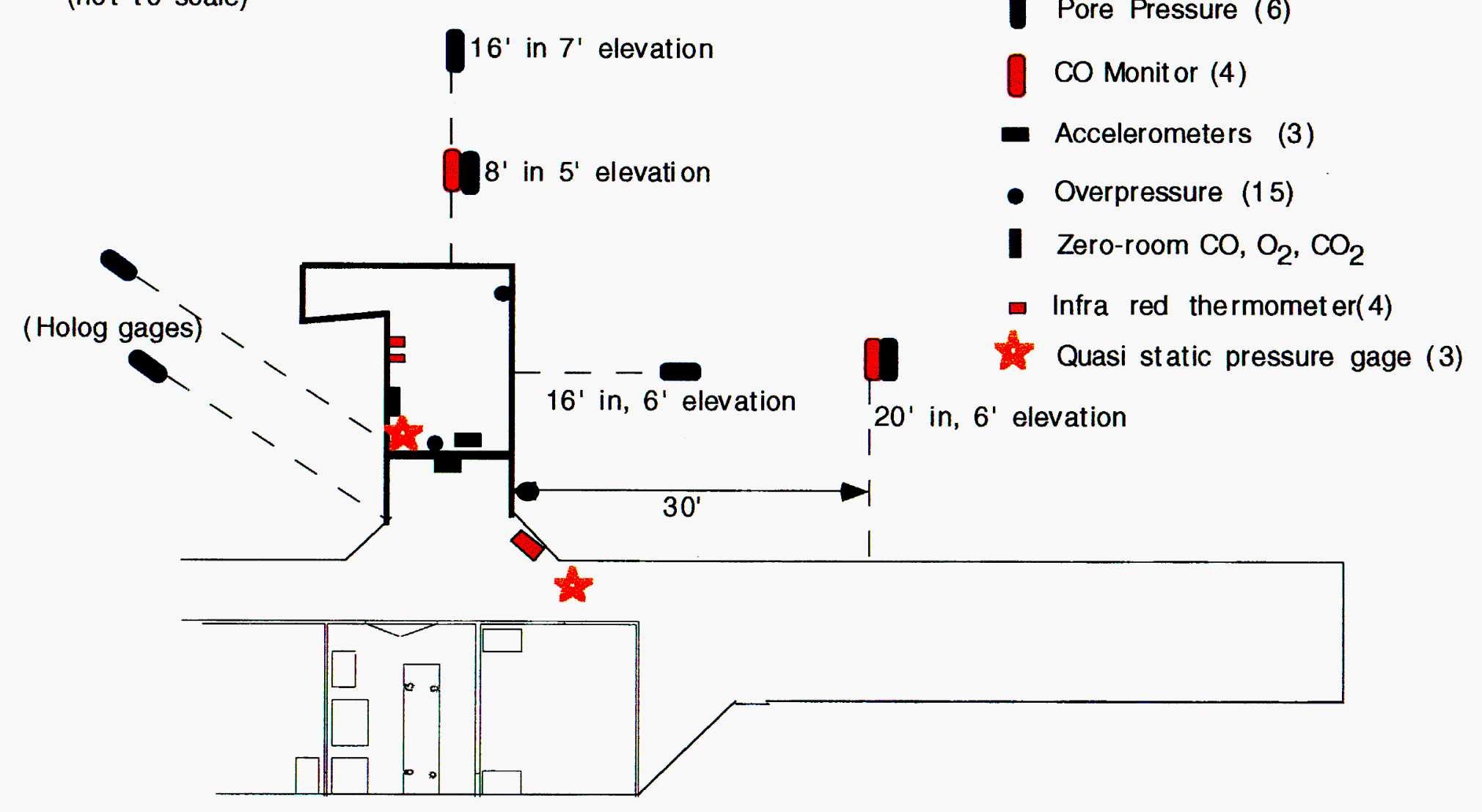




\section{BAGPIPE Containment Barrier Working Point Side}

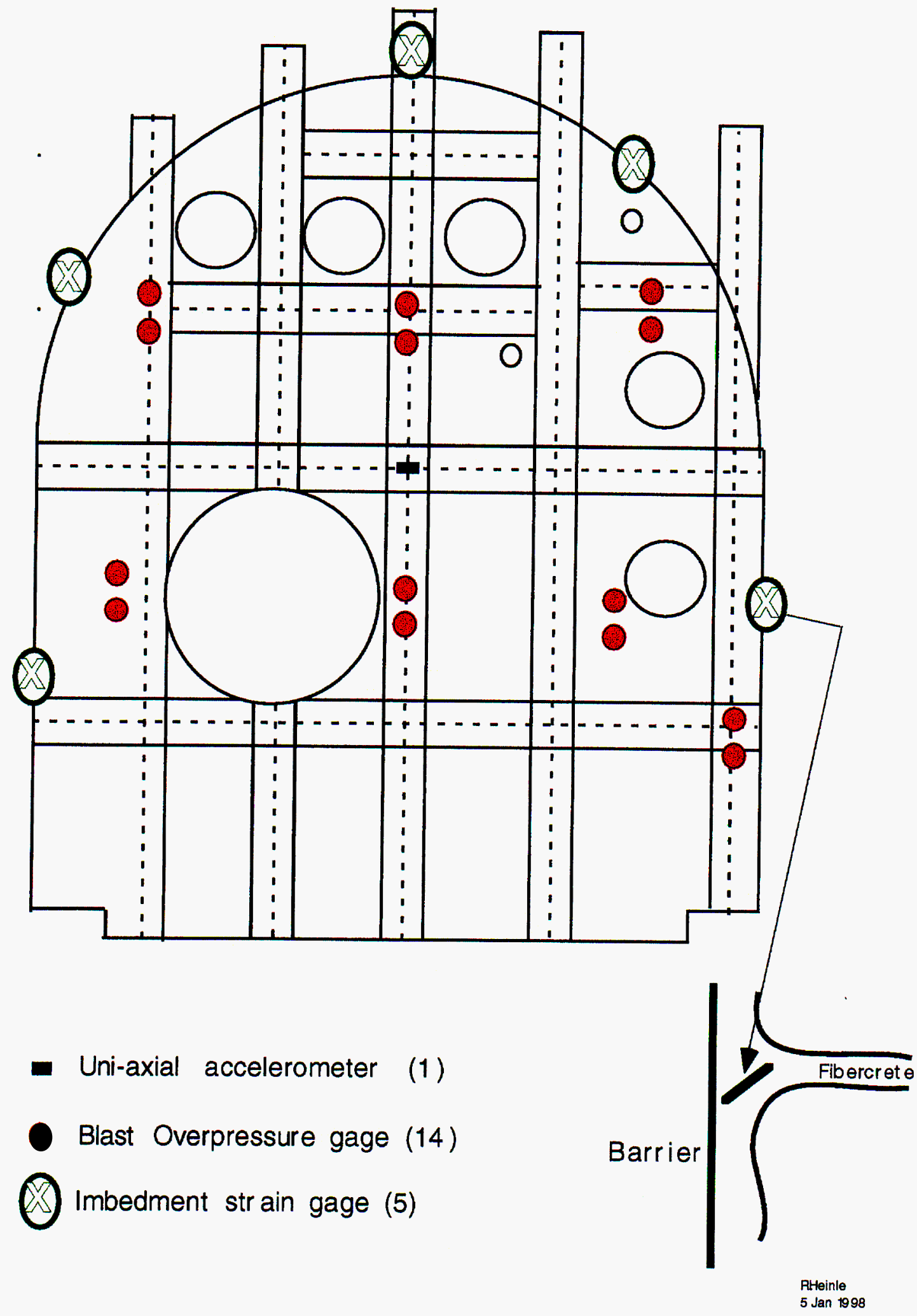




\section{BAGPIPE Containment Barrier Portal Side}

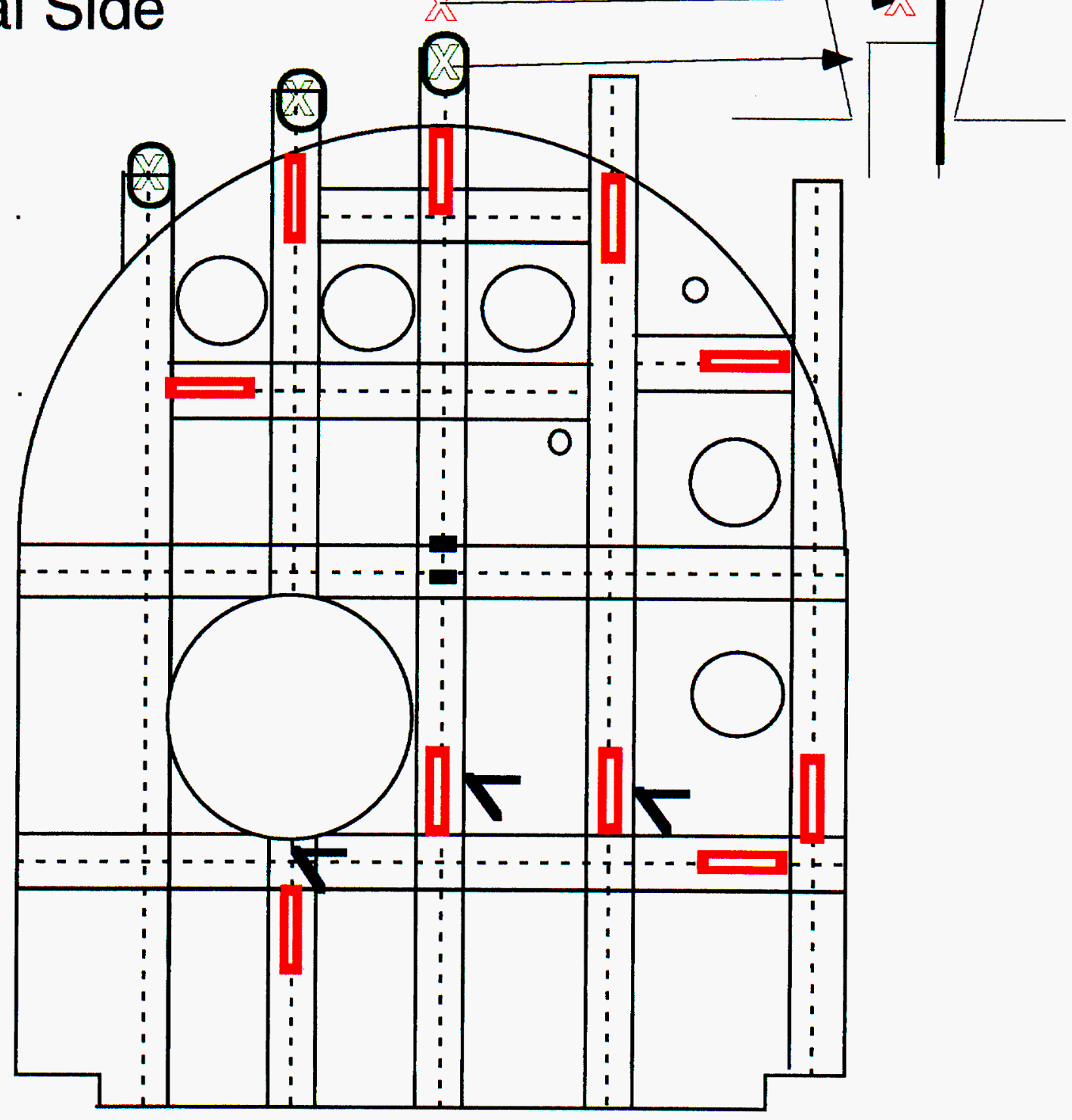

\footnotetext{
Single axis strain gage (10) Imbedment strain gage (3)

Tri-axial strain gage on web (3)

- Tri-axial accelerometer (on redwood block)

- Uni-axial accelerometer
} 